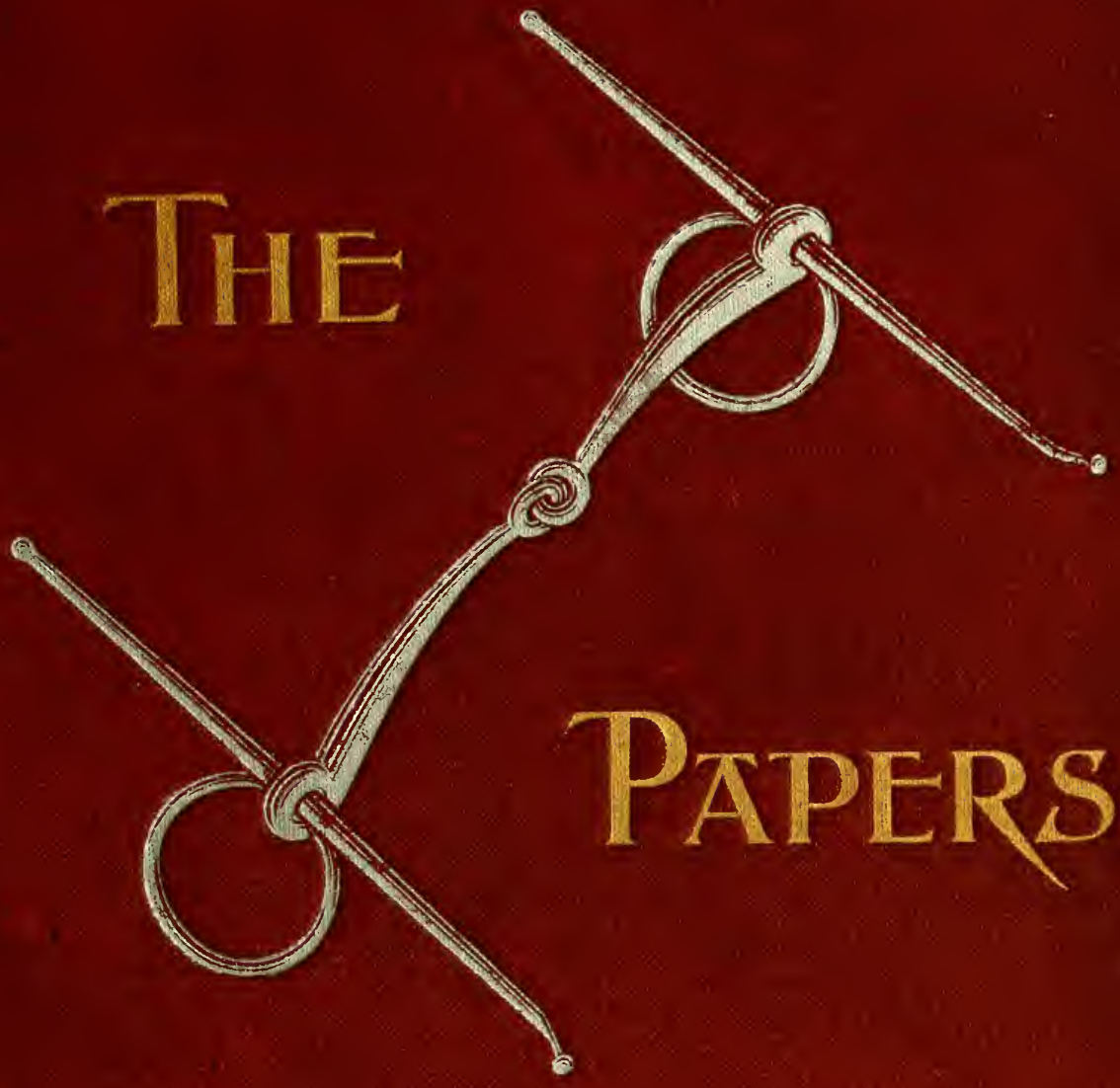

BY "SNAFFLE" 


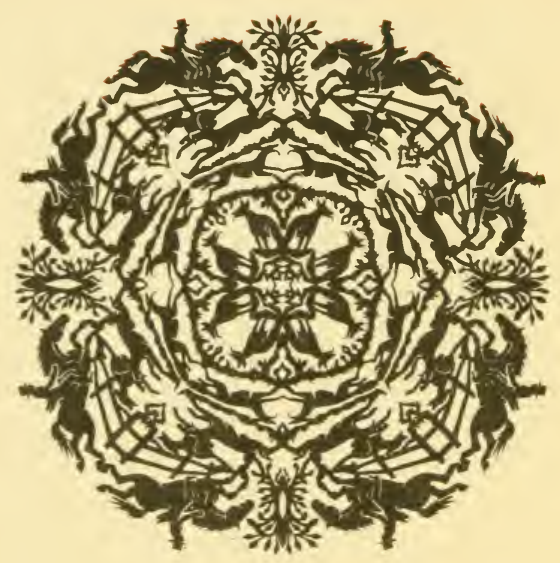

\section{JOHN A.SEAVERNS}



THE....
SNAFFLE
PAPERS
BY "SNAFre" 
、 


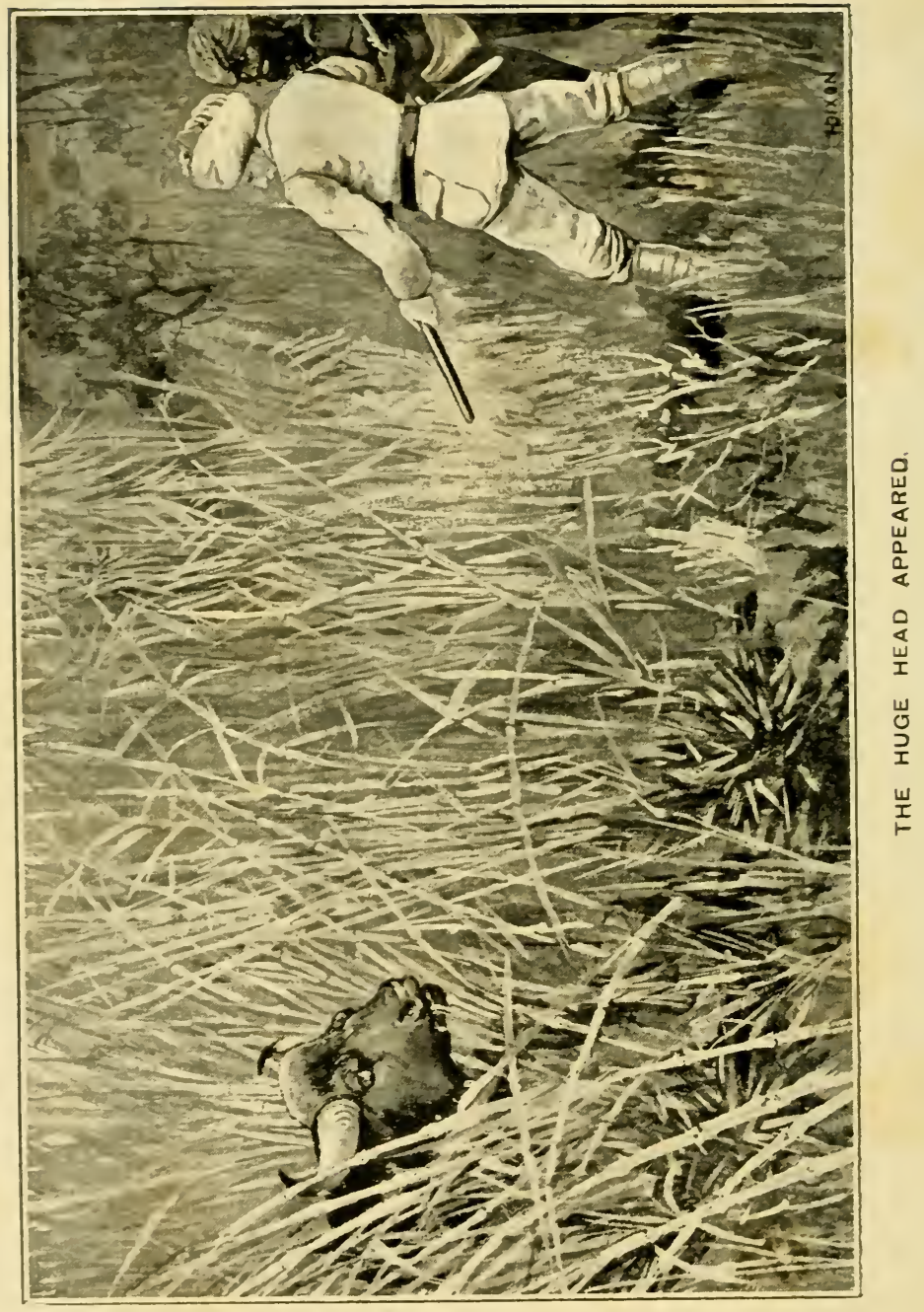




\section{THE}

\section{SNAFFLE PAPERS}

\section{By "SNAFF LE"}

AUTHOR OF "GUN RIFLE AND HOUND" "IN THE LAND OF THE BORA" ETC. ETC. is a

WITH FULL-PAGE DRAWINGS

BY

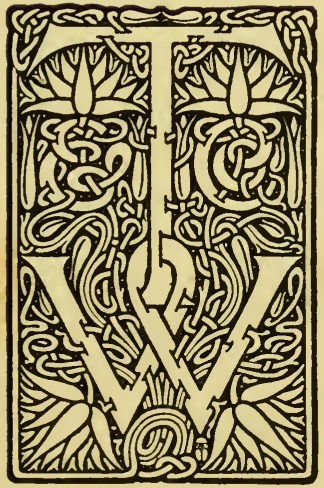

HARRY DIXON

London: W. Thacker \& Co. 2 Creed Lane E.C. के CalcutTa \& Simla THACKER SPINK \& CO. को 1898 
[ALL RIGHTS RESERVED] 
DEDICATED

To

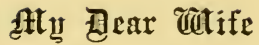

WHOSE HEARTY CO-OPERATION AND ASSISTANCE ALONE

HAVE MADE MANY SHOOTING TRIPS IN

OUT-OF-THE-IVAY PLACES

POSSIBLE. 


\section{INTRODUCTION}

THAT the reader of a book, of whatever class, has a right to expect the writer to understand his subject, is an axiom few will be found to dispute; but unfortunately it is also one frequently more honoured in the breach than the observance. Only the other day I was reading a book in which a writer on mountain sport attributed a miss to his bullet having gone low, it being, according to him, a well-known rule that in firing at an animal from above, extra elevation must be given to the rifle. These few words proved to me his total ignorance 
of his subject, and made me inclined to look upon his entire description as apocryphal; the truth (so simple a one as to be known not only to hill sportsmen, but also to every soldier and rifle-shot who has ever paid the slightest attention to the question of trajectory at all), being that, in firing down from a higher point than that aimed at, the rifle must be directed considerably below the mark. Taking the average of shots that occur in stalking, the knee of mountain sheep or goats is often the proper level at which to direct the (point-blank) sights, but it has occurred to me, and no doubt to many others, to have to aim quite as low as the hoof. The object of this introduction is, however, far from being to pick holes in others' work, but to say that I think I am fairly entitled to claim that in 
the following papers I have confined myself strictly to matters that I do know something about. I have endeavoured not only to provide something to interest individually the hunting and driving man, as well as the shooter, whether with rifle or gun, but as a rule to write in such a manner as to interest all sportsmen, even if the subject matter of any particular paper should not be that sport in which he takes his chief pleasure.

It has been remarked to me that two of the papers on rifle-shooting (Nos. Io and 23) are too highly technical. Technical they certainly are, but I venture to think they will not on that account be less welcome to sportsmen. To begin with, I, like most others, have passed through that stage of my shikar career when I was 
willing to take my rifle from the gunmaker, and my cartridges from the ammunition manufacturer, and to go out after game without even having tried either at a target. These pages may reach the hands of those who are now going through this stage, and if what I have written only induces one of them to think of what he is doing, and alter his ways, it will not have been written in vain. I think, however, that the number of sportsmen who neither trouble as to how their cartridges are loaded (so long as they do not miss fire), nor as to whether their rifles are at all calculated to give the results they desire to obtain, is a daily decreasing one; and, if I am right in so thinking, there is the less need to apologise for the dryness of the articles referred to, As to the fair 


\section{INTRODUCTION}

sex, I fear I shall not find many readers among its members; and perhaps among them some whom the one paper which specially relates to them will greatly offend. Only recently I was reading a lady's article on deer and pig driving, which contained an expression of thankfulness that her mankind were of that unselfish sort which is willing to admit her to a share of their pleasures. Then she went on to describe a roe gracefully bounding down the hillside till she raised her gun, and "it fell, to bound no more." The true sportsman would have felt, I consider, at least one pang of regret at taking the life of a creature so much more beautiful and harmless than himself; and his satisfaction might have justly lain in the fact that its death was at any rate so instantaneous as 
to be practically painless. Into such trifles, however, the lady (?, save the mark!) did not enter; but hastened on to send a bullet into a boar, which, however, got away, "leaving only a broad blood-trail." This time she does express regret, not, however, for her victim's sufferings, but for her lost bacon. Into this subject, however, I have entered elsewhere; so will only say here that I do not write for women who shoot, whilst for the benefit of those who do not and of the general reader I have endeavoured, with the exception of the articles already referred to, to write in such a style that the papers shall help them to pass an idle hour; and with this view I have also introduced three or four descriptions of travel and colonial experience only indirectly relating to sport, 


\section{INTRODUCTION}

A number of the following papers-in more or less the same form as that in which they are now printed-have already appeared in the Field and the Shooting Times, and one in Baily's Magazine. To the proprietors of these three periodicals I would here express my thanks for their kind permission to use the same.

SNAFFLE.

Drumsallie House, August 15, 1898. 



\section{CONTENTS}

PAGE

I.

On the Dogmatism of Sportsmen . . I 7

II.

The Old Pack .

III.

Twenty Years Ago

$4^{2}$

IV.

On the Road in the Herzegovina . . 55

V.

The Hazel Grouse

VI.

Sport in Shakespeare. 


\section{VII.}

Which the Young Sportsman may Read with Advantage $\cdot \quad \cdot \quad \cdot 92$

\section{VIII.}

On Dachshunds

. $\quad . \quad 94$

IX.

A RECORD . . . . . . . $\quad$ IO6

"Trade Bullets" . . . . . . I I

XI.

Old Coaching Days in the Lake District . I 23

XII.

The Finest Sport $\quad . \quad$. $\quad . \quad$. $\quad$ I 35

XIII.

Round the Boundaries . . . 150

XIV.

Conching in Ceylon . . $\quad$ i62 
$\mathrm{XV}$.

PAgE

Poor PUSsy! . $\quad . \quad$. $\quad . \quad$. 185

XVI.

A Diligence Drive in Austrian Turkey . 195

XVII.

MY MOOR $\quad . \quad . \quad . \quad . \quad . \quad 208$

XVIII.

On the Edge of the Desert a . $2 \mathrm{I} 8$

XIX.

English and German Sportsmen . . 228

XX.

In Albania $\quad \cdot \quad \cdot \quad \cdot \quad \cdot \quad 239$

XXI.

Shooting-Ladies $\quad$. $\quad$. $\quad$. 257

XXII.

Shooting-Rights of Simall Freeholders . 264

XXIII.

Dead Weight . . . . . 280 


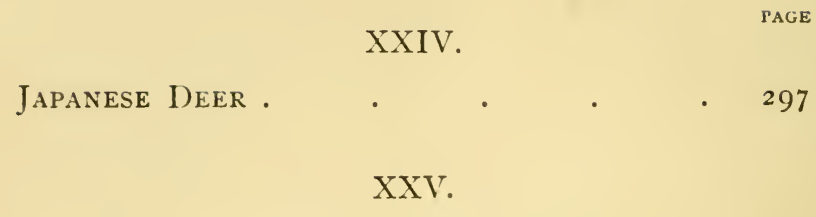

Robert S. Surtees-An Appreciation - 303

XXVI.

Racing in Ceylon . • . $\quad 323$

XXVII.

The ENd . . . . 342 


\section{LIST OF ILLUSTRATIONS}

The Huge Head appeared

Frontispiece

The Squire is not Given to waste Time . . . facing page 34

"CROOK-KNEE'D AND DeWLAPPED like Thessalian Bulls" • , 86

Held him UP, FLAPPing . . $\quad$, 107

"What the Devil did you 'alloa FOR?" “'COS I'SE PAID TO” . " $\quad 141$

Put the Tape on his Horns . $\quad$ " 148

The Fox is Safe enough . .

MAKING SURE OF HIM . . . " $\quad 225$ 


\section{LIST OF ILLUSTRATIONS}

Going best Pace . . facing page 244

Fast becoming a Professional

POACHER . . . " 268

JAPANESE DEER · • • • . N $\quad 297$

The Full-choke doubles him up ", 344 
THE SNAFFLE PAPERS 



\section{THE \\ SNAFFLE PAPERS \\ I}

\section{ON THE DOǴMATISM OF SPORTSMEN}

SPORTSMEN, by which term I here $S$ mean what the Americans call "hunters," or, in other words, those who endeavour to compass the destruction of their game by the aid of powder and lead, have had a number of epithets, more or less flattering, applied to them by various writers. I am afraid that as a rule they are less than flattering, being generally such qualifications 
as selfish, untruthful, and so on. But I think it has been reserved for me to point out that in ninety-nine cases out of a hundred they are nothing if not dogmatic. I confess I am myself; though I trust that the sharp edge of my dogmatism has been slightly blunted by a sporting experience embracing many years, many countries, many men, and many methods.

For real, downright, honest dogmatism give me a country gentleman of any nationality who has never been out of his native land and not often out of his native province. But for him there is more excuse. Those who ought to know better are nearly as bad. Not very long ago I went to a certain province, in the hope of getting some chamois stalking. "No use," was the chorus; "nobody ever stalks here; you can only get 


\section{OF SPORTSMEN}

them by driving." Now these men were not natives of the country, yet their dogmatic assertion proved totally unfounded. I soon proved by my own unaided exertions that it was a remarkably easy stalking district.

"Nice dogs, very," remarks someone when you go down to a new county; "but you won't find setters any use here, we always use pointers." In the sequel this last sentence proves to contain the whole truth of the matter. Local custom is in favour of pointers, but as for any reason that setters should not do as well it is absolutely non-existent.

I have spoken elsewhere ${ }^{1}$ of the bigotry of the German sportsman, and he is indeed a bad case. He has reduced his kennel to a

1 Gun, Rifle, and Hound, chap. xxv. 
minimum $-\mathrm{a}$ retrieving pointer and a dachshund; and I am not sure he is wrong. But this does not warrant his talking of retrievers, which he has never seen, as "poodles," or laughing at the idea of long-legged deerhounds for securing a wounded stag. The Scottish keeper with his pointers or setters, retrievers, perhaps spaniels and even beagles, and certainly deerhounds (or, more's the pity, collies now-a-days) for stalking, looks askance at the heavy retrieving pointer with the docked tail, and absolutely explodes at the idea of a dachshund as a sporting dog. Dogmatism! pure dogmatism on both sides! The German's kennel is exactly the thing for the great majority of German shootings. But his heavy pointer would soon collapse in an August day on the heather; and the dachshund, though excellent to guide one to 
a wounded deer in a woodland, would hardly get up to him on the "forest" before he was "over the march."

When we get to guns and rifles, dogmatism is rampant indeed. "English cannons" my Austrian friends call the I2-bores favoured by most British sportsmen, whilst, till recently, we pooh-poohed their I6's. "A man must be a Johnny to shoot with anything larger than a 28-bore," wrote a noble lord in the Field not very long ago. Now I must admit that although a small-bore man myself, a 28 seems rather small even to me. But as I never tried one, this again may be my dogmatism, and I certainly got some wonderful results out of a short-barrelled 24 not long ago. But for the I6 I have nothing to say. It is neither fish nor flesh, neither a smallbore nor a big-bore; and it seems to me to 
combine the defects of both. But very likely this is my dogmatism again - still I had one for some years.

I own I swear by the 20-bore. I have had almost every bore between I 2 and 24all that are made for modern cartridges, and a few besides; so, at least, I have tried those I like less. The only thing to be said against them is that the cartridges are not always at hand, if one's own run out. For this reason I intend my next gun to be a "Vena Contracta"-is it necessary to explain that a "Vena Contracta" is a 2o-bore gun taking I 2 -bore cartridges ?-and for this reason also I recommend the i6-bore to sportsmen going to Germany and Austria, where nearly everyone uses that calibre.

In this matter of guns sportsmen, however, are not nearly so dogmatic as their 
gunmakers. How many years was it before the latter were at last induced, by actual experience with the try-gun, to let us have a say as to the length of our own stocks? Then we escaped from the old straight short stock which saved the life of so many a bird. The Americans apparently have not done so yet, for I read in the catalogue of their biggest firm of gunmakers that all stocks will be sent out $12 \frac{3}{4}$ inch long with a drop (Anglice, bend) of $2 \frac{5}{8}$ inch, and departures from this pattern will be charged ten dollars extra. Our gunmakers certainly make us pay for our "scatterguns," but they draw the line at two guineas extra for gun-fitting. Now we are trying, and at last with a little success, to escape from the thraldom of "12-bore 30-inch barrels," a sealed pattern which has been crammed down the throats 
of English sportsmen pretty well ever since breechloaders came into general use.

Sometimes it is the other way; for instance, the .303 rifle. Gunmakers saw its wonderful powers, as far as initial velocity, flat trajectory, and penetration were concerned, and jumped to the conclusion that here was the ideal sportsman's weapon. For some years every gunmaker's catalogue or advertisement harped upon this, but now we hear less of it. The truth is, that the .303 rifle and similar weapons cannot be ideal sporting weapons, though admirable with an expanding bullet for certain kinds of stalking. But it smashes no bones, and makes too little blood for most countries. Above all, it is deficient in stopping power. I think the trade is now learning the real lessons the .303 should have taught them-- 
the value of smokeless powder of high initial velocity and of low trajectory, combined with stopping power and a considerable weight in the projectile. That they will ever obtain this with a smaller bore than the .400 (as a minimum) I do not believe. But such a rifle, carrying a hollow-fronted bullet not under 350 grains weight, and burning about 48 grains of smokeless powder, will, in my opinion, be the all-round sporting rifle of the future.

Just at present they are all off again, on single-trigger guns this time. I must confess I cannot see the advantage of this system; and it seems to me that some of the arguments which are used to recommend the invention are decidedly specious. For instance, we are told it gives an equal length of pull with both triggers. I never found 
yet that there was an unequal length with any gun, the distance between the two triggers corresponding to that between my index and second fingers. Perhaps some people do not press the second trigger with the second finger; and this may be a piece of my dogmatism. Let us get back to the gunmakers. Not very long ago they hit upon an excellent idea-a real addition to every sportsman's battery - the shot-and-ball gun. Every firm of note makes them now, and I believe the difference between the systems-none of which are patent-exists principally in the registered names given them by their makers. One and all of these depict, write of, and recommend them as I 2 -bores. Why, in the name of goodness? As a rifle the 12 -bore is only to be recommended for the biggest of big game- 
elephants and bison, for example. Now, in the first place, these come in few people's way. In the second, when they do, I greatly doubt if these weapons, burning as they do a very moderate powder charge (some $3 \frac{1}{2}$ drachms), can possibly give the necessary penetration for such game. At least, I always used 6 to 8 drachms in my 12-bore rifles. Shot-and-ball guns are most useful in countries where there is a little game larger than what we have in England, and this game, as a rule all over the Old World, will be pig and small deer or antelopes, none of which require so big a bullet. I was showing that of my 2o-bore "Universal" to a friend the other day.

"Would it stop a boar?" he asked; to which I replied, "I never tried; but it stops a bear, horrid." And so it does. 
Of all dogmatism, that of youth naturally bears away the bell. Not long ago I met a young man at a Levantine table d'hôte, and found him to be a brother gunner. Thinking to interest him, I took out of my pocket the cartridge of the latest thing in rifles, which had been sent me with a letter soliciting an order. It was the usual type of bullet, smallbore smokeless - a I 7 -grain "armour-clad," with a soft lead point. I told him the makers recommended it for deer-stalking, to which he said, "Well, it might do for deer, but it wouldn't for pig." Our subsequent conversation revealed the fact that he had once seen a pig shot-with a shot gun-and never any other big game at all. Yet he gave his opinion authoritatively to me, who had been introduced to sus scrofa before he was breeched-to me who, knowing what 


\section{OF SPORTSMEN}

has been done with the .303 by such men as Hohnel (two rhinoceroses with one bullet), and Glynn of Sabie Hall (five buffaloes with five shots), almost hesitated to admit that I did, and do, agree with him. 


\section{II \\ THE OLD PACK}

I T is all very well to "go to the Shires," as

1 Mr. Sawyer did, or to cross the Irish Channel and enjoy the delights of gallops on equally green and less holding pastures in Meath, but after all we never lose, I think, the old keen sense of pleasure, which dates from our knickerbocker days, and which returns when we run down for a few days with the old pack "at home."

As we emerge from the little station into the street of the quaint old market town, we 


\section{THE OLD PACK}

are reminded of the hounds at once by a broad grin under a finger-rapped hat brim, whose wearer occupies the box seat of a comfortable-looking waggonette. Is it not Bill M-, erstwhile the man who blooded us to fox, and who has now in his old age descended to the comfortable servitude of two maiden ladies? For in the provinces the huntsman by no means occupies the position he does in the crack counties; and we have known one who was not above ploughing on non-hunting days. But we can't wait, for the dogcart is. As we pass the local club we exchange a wave of the hand with the Rev. Nat B-, who, though staunch to his resolution, made the day he first took orders, never to hunt again, is generally engaged in parochial work in the neighbourhood of the covert most likely to 
be drawn whenever the meet is in his parish. Talking to him is F. E-, the most sporting of solicitors, and the worthy secretary of the Old Hunt. Now we are out of the town, and the home welcome concerns ourselves alone.

Next morning comes the jog along the familiar lanes to the meet with "the governor," who, on his confidential cob, doesn't look as if he was verging on the scriptural limits of man's age. His broad ridge-and-furrow cords and stout-soled tops make our leathers and Bartley's look rather dandified; but no matter, we have other things to think of. "The Forty Acres in roots this year?" "Yes; and held more birds than I ever saw there," is the answer. "Why, oh why, were we at Hong Kong, or Meerut, as the case may be, then?" 


\section{THE OLD PACK}

"Yes; that hill pasture never was any good, so I planted it up with larch in '9-. Rare covert it is now ; Johnny B k killed three woodcocks there on one day last season." Then we are off the old place, but remarks on __'s farm, and how such and such a place has recently changed hands, fill up the time, till we are surprised to see how soon we have reached the meet.

The meet! The last we were at was perhaps at Dunshauglin, or Badby, or Thorpe Thrussels. This is rather a different thing. Counting ourselves, there are just six pinks, perhaps thirty horsemen all told, and two vehicles. But what a hearty welcome to contrast with the "How do?" we got there.

First it is the squire. 'Pon my word, he does not look a day older than when he 
first took the horn. Was that the year before or the year after we went into trousers? Anyhow, it is over a quarter of a century ago. $\mathrm{He}$ is as monosyllabic as ever, but the grip he gives your hand makes your fingers tingle. Close to him is Will, the kennel huntsman and whipper-in, who has been with the pack as long as the master, and is absolutely autocratic in the feeding-house, and very nearly so on the flags. Like his predecessor yesterday, he, too, is on the broad grin. Then there are a couple of the governor's cronies who remember us in long clothes, and half a dozen farmers, some of whom do the same, whilst the others played cricket with or against us in the holidays later on.

But the squire is not given to waste time. With a slight whistle, he turns his hog- 


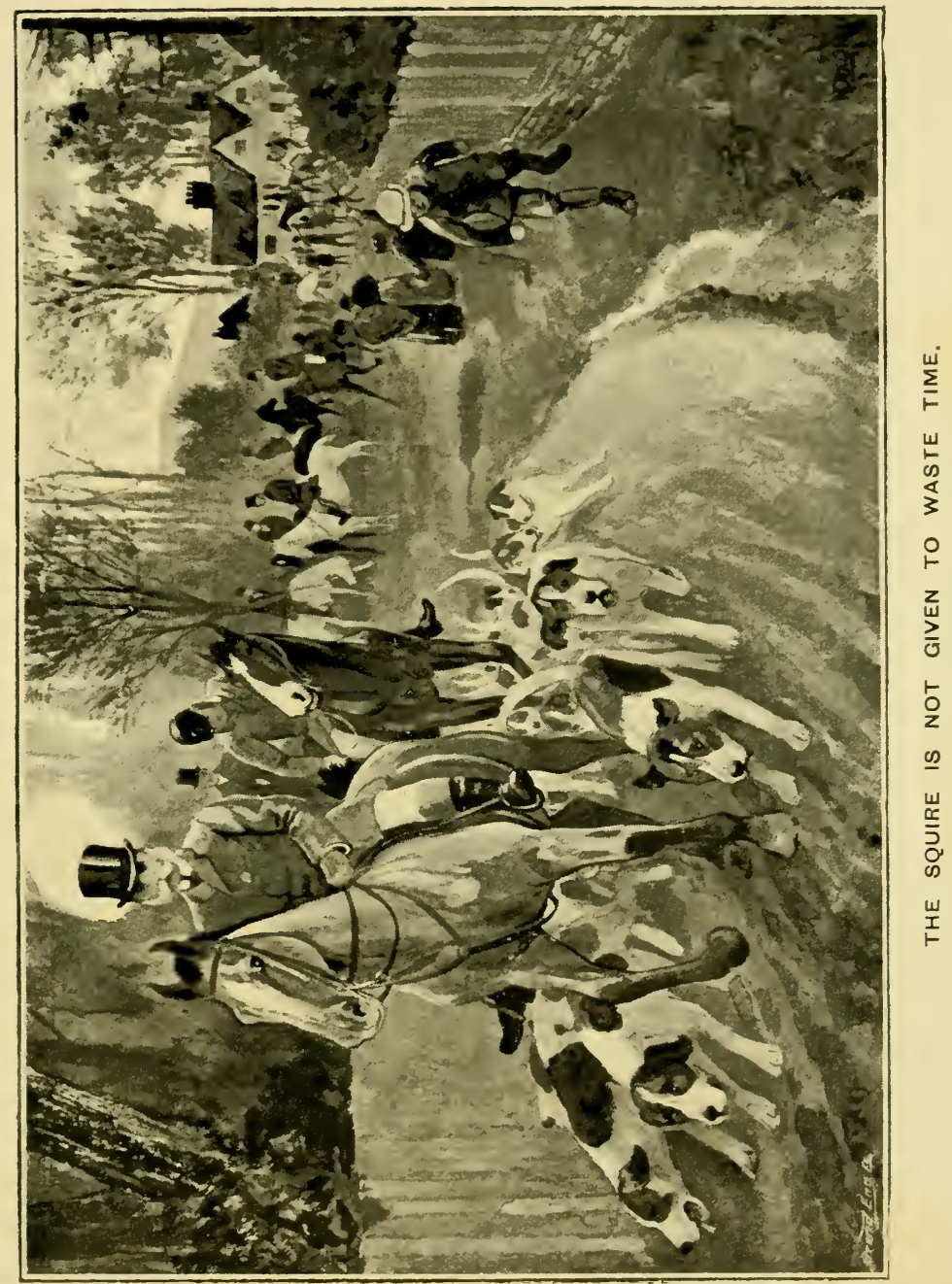





\section{THE OLD PACK}

maned horse off the green (of course the meet is on a village green, and the spectators principally women, children, and geese), and jogs down the road. Not much more than a furlong on he turns to the right, and then a muddy, stony lane leads us to the covert.

This is a leg-of-mutton-shaped patch of young larch, the trees being some years older at the broad end where the squire has just waved in the hounds with a "Eleu in, there." The other side of the high-road we have just left is a big woodland; but it is up-wind to-day, and master and man commence a duet of whip-crackings and cheering which is calculated to turn any fox from this point.

"Now then, youngster, as I suppose you mean to show us all how to do the trick, 
you'd better come with me," says the governor, and leads the way to one side of the, so to say, point of the covert. Meanwhile, hounds have found, and are pushing their quarry busily about the thick stuff. So you are not surprised, on hearing a cough, to look round and find the bulk of the field silently waiting behind you. Not the men these to spoil their own sport.

Just then a magnificent dog-fox goes away not two-score yards in front of you. All are silent until he has disappeared through the next fence, and then a cheery "tally-ho" bursts from nearly everyone. But the pack requires no assistance, for they are close at his heels, and like a waterfall they pour out of covert, under, over, and through the fence. A slight swing, a hover, and they are away! Master and man come pounding 


\section{THE OLD PACK}

along on opposite sides of the spinny, forrardawaying at the top of their voices. But the pace seems to us rather too good for politeness, and we are off before they reach us, making the best of our way to the place in the first fence - a big hairy one-we picked a couple of minutes ago.

Good as the pace was when they first left the covert, the mixed pack has kept it up for twenty good minutes, and the field is considerably reduced. We have been lucky enough to keep our place; to our left is a local doctor, riding, as cloctors generally do, as if they could set their own bones. Will is about a field behind, but, as we know, he got all the worst of the start, and between him and us is a young horse-dealing farmer, on something that looks rather like a 
thoroughbred. A few more men are descending the slope we have just left behind, but they are riding to us rather than to hounds. This is the bottom. A complication of muddy, swampy stream, with rotten banks, ragged alders, half-broken rails, and a piece of chain to keep cattle from walking up the bed makes an obstacle which causes us to rejoice that we are on an Irish one. By giving him his own way we get over and tackle the "bank" the other sicle of the valley, perhaps four hundred feet high, and really nearly as steep as the proverbial "side of a house." Up and up we struggle, hounds getting away from us at each step. Fortunately the fences are full of gaps or else provided with handy gates, for who could jump at this angle? At last our sobbing steeds top the hill, but hounds are 
gone. The where is hardly doubtful, for a furlong on begins a wood, one of the many with which the country is dotted. They must be there, we argue, and spur our sobbing nags into a canter. As we progress they catch their wind by degrees.

Right! the old oaks shake with the melody with which the pack are driving their fox through the woodland. Let us hope they haven't changed. We are able to save our horses as they work their way along parallel with the ride we are on, and still we get to the far end first. "Whoa, fool, vot are ye champing the bit for?" to quote Mr. Jorrocks. Yes; there he goes, and looks fresh enough, too. But it is a hunted fox for all that. We rein back a yard or two to get room to shove at the wattled stile at the end of the ride, and as 
40 THE OLD PACK

we get over Will comes round the other side of the wood. "Away, away, away!"

For the next ten minutes or so the country is really delightful. There is a good deal of grass, and the plough rides light. The fences are easy, with gaps for those who like to go and look for them; and even when here and there we get a big place, the odds are the gate in it is no higher than a sheep hurdle, and unlocked to boot. The pace remains good; we have been running over forty minutes, when-what is this?

"This" is Great Woods, one of the drawbacks to fox-hunting in the old country. Their extent is numbered by thousands of acres, and when once you get into them you may have to pound along for hours in hock-deep rides to keep with the pack. Neglect to do so, and you are sure to be 


\section{THE OLD PACK}

slipped. Confound it! here we shall spend the rest of the day.

But what is that? Tally-ho, forrard! It is ride now, to see if the fast-sinking varmint will make his point. How the pack strive! He will! He won't! Who-whoop! and they roll him over under the very boundary fence. Who-whoop! Who-whoop!

Well, they can't say we haven't shown them the trick this time. But who is this who emerges from the lane on the left? The squire! and the governor! Presently Will comes up to us. "Please, captain, squire says would you like a brush to put with yours from the cut-'em-down countries?" And, having said, explodes.

Never mind; there is worse fun than a day with the Old Pack. 


\section{I I}

\section{TWENTY YEARS AGO}

ONE fine evening in the later seventies found the British India Steam Navigation Company's ship Africa leaving the harbour of I'oint-de-Galle with myself and my battery (a double I2-bore rifle and a ditto ditto gun) on board. When I say "fine" it must be understood that I do not mean that the weather was good. It may have been, but with the exception of the first three months of the year few evenings in Ceylon are without clouds, even if rain 
does not actually fall. But to me it was a great day; for, was I not off to visit India for the first time in my life? and, moreover, was it not the very first slice of leave that had fallen to the lot of a junior subaltern? Either of these things would have made it memorable. To be sure, the slice of leave I had got was but a small one-fourteen days ; but I had determined to get a lot into the time. One precious day was already gone in getting to Galle, but that night sufficed for our short voyage; and, without losing a minute at the little Indian port where I landed, I inducted myself into a gharry, and started on a drive which lasted well into the afternoon. At last I reached the spot where the road was no longer of any use, and found a pony and coolies waiting. Having handed over my gun-cases and my box 
(this latter in Ceylon and Southern India replaces the Gladstone bag, as it is rainproof and suitable to a coolie's head) to these latter, I mounted and followed the active syce for some hours along jungle paths, till, long after dark, I heard a cheerful "coo-ee," and was soon shaking hands with my old schoolfellow, Erskine, at whose hospitable instigation my journey had been undertaken.

When our dinner in the bare whitewashed room of his temporary bungalow had been discussed, and we were ensconced in two long chairs in the verandah, he unfolded the plan of campaign.

"The best chance you have of getting any sport is to go straight on to the Annamullais," said he. "Here there is nothing that you would not get in Ceylon-sambur, jungle sheep, and leopards, and, if you 
stayed all your leave here I could not guarantee you a shot at one of them. But the hills I speak of are full of game, elephants (which of course you know you mustn't shoot here), tigers, deer of sorts, ibex (which you haven't time to go after), but above all, bison; and it will go hard but you will get a shot at them, for I have ordered the best shikari about there to meet you at the hut."

"Is it far from here?" I asked.

"Well, the way is a bit rough," was the reply, "and as you don't know it you can't go faster than the syce, so there was no use laying a dawk. My pony will take you all right, but you won't get through in one day. If you are tired of it, come back here; but if you prefer to run it to the last, go straight down to the coast and catch the steamer 
there. In any case keep the pony there, but don't let him be left out for fear of a tiger."

When I woke next morning my baggage had already started, and I soon followed. A long day's ride brought me to a dilapidated looking dawk bungalow, at a point where we crossed a road, and here I slept with the help of some bedding Erskine had sent. Next day the path was rougher and wilder than ever, and rose continually. At noon we made a halt of some hours, and then went on, mostly through thick jungle, often on the edge of terrific khuds, till, before dark, we reached a roughly made hut where a couple of hillmen were waiting. One of these was the shikari, and a pretty highflavoured one he was, as I had occasion to know, for many a weary hour I tramped after him through the steamy jungles. A 
man that Erskine had sent had soon some dinner cooking, and everything seemed to be comfortable for the night, when the syce came to me and asked where the pony was to go. This was a puzzler. The hut, which contained a churpoy and a stool only, consisted of (if I may so call it) one room only with a door of branches fastened on a bamboo frame. At one end of the hut the roof overhung and formed a sort of verandah, where the men had their mats and where the fire was. There was no alternative; the pony had to share my apartment, and he did. Four of my precious days were gone already, I reflected that night; and the next night added another one to the number, for we saw no game, at least only small deer at which I would not fire. On the sixth day we saw bison tracks, but not fresh enough to 
follow; and also the fresher "pugs" of a tiger, but still no game.

On the seventh day I saw my first bison. We struck the trail of a small herd early, and followed it for hours. At last it led us to the crest of the hill, where the shikari beckoned me excitedly. Yes, there they were, about six hundred yards away, three of them, but evidently disturbed and moving on fast. At that advanced hour of the day it was obviously useless to follow. Before we reached the hut I bagged a fine stag sambur, whom we surprised feeding in an open glade. A ball from the smooth-bore, which I had in my hand, broke his back just as he was off.

Next morning I sent a coolie to Erskine, asking him to come over, as I feared I could not otherwise see him again, but this he was 
too busy to do. The day was again blank, till towards evening we came on the fresh slot of an apparently very large bull. At the shikari's suggestion we went home at once, so as not to disturb him then. The following morning found us on the trail, and to my delight it grew fresher and fresher. At last the shikari seized my wrist, and gazed intently into the bamboo jungle in front. My eyes followed the direction of his, and after a bit I made out a patch of slatecoloured hide. It was the bull.

With the impetuosity of youth, and disregarding the gestures of my companion, I at once levelled my weapon and fired. The sound of a heavy fall followed, and then a struggle, a crash through the covert, and silence. The native shook his head.

When I had reloaded, I hurried to the 


\section{0 \\ TWENTY YEARS AGO}

spot. Here was blood, nay more, splinters of bone. The bull was as good as mine. The shikari made signs (it was our only means of conversing) to me to sit down and lunch. I angrily refused. I would have the bull. Reluctantly he proceeded; and, of course (as I now know), we moved the animal again before he had got stiff, and followed him all that afternoon in vain. The very blood ceased to show.

I returned to my hut in despair. The next was my very last day; was I to go home empty-handed? I called the shikari into counsel; he was all grins.

"Shikari say all right, sar," interpreted Erskine's bearer, a coast Tamil, "that cow ver much shot; or go quite away to-day. Soon find morning, sar."

After this I could hardly sleep for excite- 


\section{TWENTY YEARS AGO}

ment. Two hours after sunrise we struck the trail where we had left it the day before, and followed very cautiously. Not an hour afterwards there was a crash in the jungle close in front. We ran on, and reached a sloping bank. The bull was limping down it, straight away from us. I aimed at the root of the tail, and the shot sent him rolling to the bottom of the little valley. I followed jubilantly, not even reloading. All at once the bamboos in the bottom parted, and with a moaning bellow the huge head appeared. The shikari, however, grinned more fiendishly than ever. I sighted just above the eyes, and fired my second barrel. When the smoke cleared, the bull was lying dead. After a drink of cold tea we proceeded to a post-mortem, of which, and of the shikaris pantomime, the following were the results. My first shot 


\section{2 TWENTY YEARS AGO}

had been unwittingly aimed at the flank, for I had not realised what an enormous animal I had to deal with. It had, as a matter of fact, smashed the stifle, and I suppose it was this that discouraged the beast from charging, for from what I have read since of bison-shooting few bulls die as pacifically as mine. The second shot broke the spine; and so, when the beast reappeared, he was really sitting $u p$, and his bellow was an empty menace, for he could not have moved. The last shot penetrated the brain and came out at the back of the head.

That night my two heads were packed up, and the shikari well rewarded. The next morning saw me en route for the coast. We sailed that night, but passed the next day loading and discharging cargo at another small port, so only reached Point de Galle on 


\section{TWENTY YEARS AGO}

the fourteenth day of my leai'e, at daylight. To my horror I found the coach only left at night, and reached the capital at eleven or so next day. And I was due on parade at 6.30 !

While I was distractedly rushing about asking everybody's advice, I met the skipper of the steamer I had arrived in. "Why," he said, "I go on to Colombo to-night, and generally get in about half-past six. Won't that do you?"

"No," I said, "I fear not. I have to be in uniform and on parade by then."

"Well," he said, "I'll stretch a point. I'll be off the port before six and send you ashore in a boat before I anchor."

The good fellow kept his word. A few minutes after six next morning two lascars landed me on the breakwater, then in its first stages of construction. I ran to my quarters, 
where, as requested by telegram, my things and servant were all ready, and at half-past six I was duly present on parade.

Afterwards I went back to the ship to get my luggage, and above all my heads, which hang on the wall opposite me as I write. Of the bison I think I have every reason to be proud, for the horns are no less than thirty-two inches across the span (outside measurement), and each measures nine-andtwenty inches long, being sixteen and a half inches in circumference at the largest part. 


\section{ON THE ROAD IN THE HERZEGOVINA}

W OT many years ago a paper on the roads of the Herzegovina would have been of a similar nature to the oftquoted one on Icelandic snakes, "There are no snakes in Iceland." But the Austrian occupation of this Turkish province, which will soon complete its fourth lustre, has to a certain extent changed all that. At least, there are not a great many roads yet; not, indeed, nearly as many as are urgently 
wanted; but those that there are, are well graded, and provided with bridges and culverts where necessary. It is true that they are quite without parapets, and as the bulk of them wind along hillsides this is a fruitful cause of smashes. But one can't have everything in eighteen years, and the traffic that goes out of a walk is very limited.

The principal and, as I suppose, the oldest, of these new roads is that which follows the river Narenta more or less up from its mouth at Meković, through the capital, Mostar, and then to Konjića, where it enters Bosnia, and terminates at the Bosnian capital, Bosna Serai, or, as it has been called of recent years, Sarajevo. This is certainly an excellent road, though, of course, it is pretty well collar work all the 


\section{IN THE HERZEGOVINA}

way up. Just before we get to Mostar, after crossing the Dubrava-a great place for wolves in winter, by the way-there are a few miles of steep descent into the Mostar plain. Once the capital is passed it is gradual ascent up a winding and romantic valley all the way. A second principal road, still a post-road, for on the one just named the iron horse has run the diligence "off the line" already, is that which joins Mostar in succession to Nevesinje, Stolatz, Gatćko, and Trebinje, whence another diligence runs to Ragusa in Dalmatia. Lastly, there is a road from Mostar to Ljubuski in the west of the province, about the only one on the right bank of the Narenta.

So much for the roads themselves. But the main interest thereof lies after all on those who pass along them; and it may as 
well be conceded at once that nine-tenths of the traffic, even on these new roads, is not wheeled.

Let us begin with the capital. Although every attempt is being made to improve the streets, it must be said that at present all traffic has to pass by one route-as a matter of fact the Metković-Sarajevo road. For part of the way it is doubled by a narrow parallel street, with blind turnings leading into it; but both are generally choked with cabs, driven badly and recklessly by Turkish boys, strings of pack-animals, and troops on the march. So it is clearly not the place one would care to work an awkward team through, especially as at its narrowest, crookedest part there is a sharp and totally unnecessary hill, which the municipality does not seem to dream might easily be levelled. 
Yet at this very spot the mounted troops are continually messing with their forage, and blocking the street with horses and waggons -a thing which surely would not be permitted elsewhere.

The Mostar cabs are one of the nuisances of the place. Dear, dirty, and badly driven as they are, they are, nevertheless, perhaps more of a nuisance to those who do not use them than to those who do. During a few months' residence I had several narrow shaves, and though a report to the town sub-prefect always ensured the jarvey's being locked up for a day or two to cool his ardour, the nuisance seemed to abate but little. Something has been done to abate the second nuisance, the pack-animals. Firstly, the number which may be led by a single man or woman is limited to three, whereas 
formerly five or six was not uncommon. Still it is wonderful how much road a man and three horses, loaded, say with straw, and linked by ropes ten feet long, will take up. Secondly, their guns have been spiked, in other words the bells on the horses' necks must be plugged with grass before they enter the town. But it often falls out, and nobody seems to care.

For a capital with a garrison of a good many thousand men, Mostar is singularly deficient in private carriages of any description; and the bulk of these, as in so many places abroad, are of an appearance calculated to make one wonder at the time our improvements in coach-building take to reach countries so easily accessible. For shooting purposes the India tonga would be especially adapted: to the ponies of the country, a suitable pair 
of which ought to be bought for about $£$ I 2. I gave a drawing of one to one or two officers of the garrison; but the continental mind is hard to wean from four wheels; and no wonder, considering how great a part the antiquated wheel-brake plays in their method of driving.

Once away from Mostar, wheeled traffic becomes very scarce. On some of the roads the post-cart may be met. This is a purely military affair. The driver is a native soldier of the Transport Service; the ostler who brings out the change of horses on the road is another, and like him wears a fez and baggy scarlet breeches. Not only is the guard armed, but on the back seat of the concern sits another escort-an infantryman with loaded rifle. Besides this, the road the coach runs on is patrolled by troops and 
gendarmes. These precautions are practically no longer necessary, but, of course, their discontinuance is difficult As for the vehicle itself, in summer it is a low open char-à-banc with an awning and side-curtains, and in winter a coach body with low driver's seat in front, and one behind for guard and escort. Rarely we may meet a waggon, or the carriage of some civilian on his rounds, but, as a rule, the only thing we shall pass will be pack-animals. To these I must return presently. One district there is, indeed, where an especial form of vehicle is to be found, but there are no roads there, only the roughest tracks. I refer to the ox-waggons of the Nevesinjskopolje, a tableland some three thousand feet high, almost in the centre of the country. These waggons are the roughest home-made affairs possible. The 
wheels have, nevertheless, what we consider a modern improvement, the so-called tangent spokes, and these, no doubt, they have had for centuries. The felloes are still more characteristic, and consist of four naturallycurved pieces of wood. The history of these is peculiar. On the steepest slopes of the Velez Range, which fringes the one side of this great plain, and which is covered with beechwood to about four thousand feet elevation, the snow bends down the young trees just above the ground every year. When summer comes the struggle for light and air in these neglected woods causes the sapling to shoot rapidly straight upwards. It thus takes the shape of a $J$, and when it is about twenty years old the native cuts out the circular segment and carries it off with a pack-horse, with perhaps a couple of dozen 
more, leaving the rest of the trees to rot. It is just worthy of remark that those that are not so destroyed eventually strike down to the lower ground, and at forty to fifty years old present no signs of having grown in this way. For this, however, the snow, which every year brings down stones, earth, and decaying branches, is partly responsible, in that it covers them up.

The ordinary tourist does not go off the roads at all in the Herzegovina, rarely, indeed, off the railroad, and it must be confessed he sees very little of it. Personally I saw a great deal of it, and it was rarely that I heard of two Englishmen having been before me, sometimes of one, and very often I had the satisfaction of knowing I was the pioneer. But for such journeys one must leave all hope of roads behind, and take to 
the bridle-ways-I cannot even call them tracks. I thought I knew something about bad roads before I went to the Herzegovina. But I found out that all those I knew before in various corners of the earth were only comparatively bad, whilst here they are superlatively bad. I don't mean all of them by any means, and much has been done to improve the principal ones, but some places are really calculated to give one " the creeps." The horses are very sure-footed, though how they can be so, with their feet covered, as they are, with the Turkish barshoe, is a mystery to me. Nor is the situation improved by the knowledge that, perched up as one is in an abominable Turkish saddle, one can give no assistance should the horse require it. Unfortunately, I had committed the folly of not having an 
English saddle with me. After a few days of the other sort I preferred to walk; and did so.

Although one may be on a track which is almost undiscernible among the rocks, if it is one that joins two centres of any importance we shall meet plenty of traffic. As a rule, the passers-by consist of peasants, with a pack-horse or two. The men are gaily dressed in brown jackets, braided with red, red waistcoats, blue breeches, and red leggings. All wear fez or turbans, and round their loins is a sash, green if they are Turks, red if they are Christians. The women are always in white, their homemade woollen dresses being turned back and fastened behind to show the breeches of similar material. The pack-saddle of the country is peculiar to our ideas, for it comes 


\section{IN THE HERZEGOVINA}

half-way up the horse's neck, and is so high that when it is merely covered with the usual blanket the horse seems to be loaded already. It is secured with one girth, a crupper and two cords running under the horse's forearms, a practice which accounts for the scars one universally finds there.

The people are very lazy about off-saddling, and one often sees a pony grazing for days with his saddle on. A fair load is considered so oke, and an oke is over two pounds and a half English, say, with saddle, sixteen stone dead weight to be carried ten hours or more by a pony thirteen handsnot a bad performance.

Another commonly-met sight consists of a gendarmerie patrol - two men, as in Ireland. This duty is tremendously severe, as the patrols go out for forty-eight hours at 
a time, and every portion of the country, mountains, forests, etc., has to be patrolled in turn. On the Montenegrin frontier the monotony of the duty is often broken by a rifle bullet; three gendarmes were killed in 1895. Except those who escort their officers in this district, the gendarmerie are not mounted, however, so can hardly count as traffic. Civil servants, foresters, engineers, telegraphists, and officers are the horsemen one most often meets. There are no postmen, for there is no post, nor does the doctor make his rounds on horseback, for there is no such person. The priest does, though, or perhaps I should call him a monk, for they are all Franciscans ; and here, like nowhere else, they wear a fez and long moustaches.

Flocks of sheep and goats and herds of 


\section{IN THE HERZEGOVINA}

ponies and cattle we, of course, meet frequently, according as the season regulates the feeding-grounds. In summer they are all high up, in winter all low down. But winter at high elevations is not to be spoken of lightly. I have tried it, but I don't want to try again; and, as a rule, those whose duty obliges them to travel then, take good care to go round by the lower roads which follow the beds of the rivers. There snow is rare, and does not lie long.

"As many of the Turks have considerable wealth in horseflesh, it is not uncommon to meet trains of twenty to thirty ponies with good pack-saddles (not a bridle among them) and rugs over their loads, their jingling bells reminding one of past days in Andalusia. But here is no arriero; the rear is brought up by one or two Turks on 
better-class horses, which, under the double influence of the murderous bit and of the corners of the shovel-stirrup, carry themselves smartly enough. Although deprived of his arms, the Turk (so the Mahometan Slav is always called here) still looks unmistakably the lord of the country. His carriage and bearing are confident and haughty, but I found them very good fellows, and more pleasant to deal with than the Christians; though I have known the two combine to get to windward of the stranger."

I quote the above lines from my own book, In the Land of the Bora, because I think it fairly describes the only familiar object of the road I have not referred to before. I think I have made it pretty clear that the Herzegovina is not yet, at all events, 


\section{IN THE HERZEGOVINA}

a country for the lovers of the coach-horn and the long thong (although the Metković, Mostar, Sarajevo road would form no bad commencement to a driving tour, say to Buda-Pesth); but to those whom riding tours please, and who can rough it a bit, it has a great deal to recommend it, not the least inducement being that it is extraordinarily cheap. 


\section{V \\ THE HAZEL GROUSE \\ (Tetrao Bonasia)}

W $\begin{aligned} & \text { Y recollections of this beautiful, if, } \\ & \text { perhaps, not very sporting, bird, }\end{aligned}$ have been recalled by a paragraph in the Shooting Times, for January 2, 1897, in which the paragraphist wonders why "this excellent game bird, which belongs to the grouse tribe, should never have been introduced into Scotland, when the conditions of climate and terrestrial surroundings differ but slightly from those of Scandinavia." 
The writer styles the bird the "Norwegian hazel hen," and I am by no means sure that he does not imagine it to be found in Norway (and, of course, Sweden) alone. If so, he is, of course, greatly mistaken. I first came into contact with it-perhaps I ought rather to say, it first came into contact with shot from the barrels of my gun-in the Grand Duchy of Luxembourg, as related in the Field for Dec. 3I, 1892. Since then I have met it in most European countries - as far south, indeed, as the Balkan Provinces of Turkey, and, I dare say, though I have no book of reference at hand to verify the fact, that its range extends to the Caucasus, and, perhaps, even further to the southward and eastward. Be that as it may, from the Arctic Circle to Turkey is a long stretch. 
I was the more impelled to notice the paragraph above quoted because I, myself, had so recently made the same remark, i.e. suggested the acclimatisation of the bird, not, indeed, in Scotland only, but throughout the British Islands, in my book, In the Land of the Bora; but when the writer goes on to suggest that "the common grouse (a very wrong name, by the way, to give Lagopus Scoticus) and black-game may be rivalled on their own moors by their Scandinavian cousin," he does, indeed, give himself away. The very name he uses - "hazel hen" - might have taught him that the species under consideration is not a moorland bird.

In case he may retort upon me by saying I am not acquainted with the bird in Norway, I propose to quote two sports- 
men who are, and the first gentleman I shall put into the witness-box is Mr. Edward North Buxton. He says: "In the densest groves of spruce a rapid scuttling of wings will indicate the presence of a covey of hjerpe, or hazel grouse, the smallest and perhaps the handsomest of the grouse tribe, and, as some think, the best eating. They only fly up into the adjoining spruce, where the brown bars of the breast, so conspicuous when the bird is handled, harmonise perfectly with the twigs."

This writer, though he gives a capital picture of a covey of hazel grouse, is writing of elk-shooting primarily, so it may be advisable to produce further testimony. Sir Henry Pottinger, in an article on "The Shot Gun in Norway," must, I think, be 
allowed by all to be an authority. This is what he has to tell us (after saying of the black-game that they haunt the margins of the open morasses where they can run out of the wood to feed or bask among the patches of heather or willow) :- "In similar localities, but rarely given to quitting the shelter of the trees, we find the beautiful little hjerpe (hazel hen, gelinotte), the smallest of the grouse tribe, with flesh as white as that of a partridge. Singularly cunning or lucky must he indeed be who finds a covey of these birds out in the open. Directly they are flushed they take to the trees, and there sit motionless, uttering at times a faint shrill whistle, which often betrays them. For unpractised eyes they are not too easy to see. I recommend the sportsman to put old-fashioned scruples 
into his pocket, and shoot these birds sitting, whenever he gets the chance. They have a habit of darting from the trees on his approach, and luring him into the wood by the sound of their repeated flight; for they seldom fly a hundred yards before they perch again, escaping just out of shot as the too eager pursuer comes noisily up. On the wing they are extraordinarily fast, and he who managed to kill a right and left at hazel hens, going like bullets through the trees, may fairly congratulate himself on having performed a pretty, and not too common feat with the gun. The birds are delicious eating, but their flesh is too delicate to bear well the freezing necessary for export."

With all that these two writers say my experience (gained elsewhere than in 


\section{8

Scandinavia) coincides, except, indeed, that I am inclined to consider the lesser Indian sand-grouse, rather than the gelinotte, "the smallest of the grouse tribe." But very likely Sir Henry had the European grouse in his mind-possibly, indeed, has no Asiatic sporting experience. ${ }^{1}$ It is also worthy of remark that one of our authors speaks of spruce and the other of willow trees. I have invariably found the bird in beechwoods-the commonest kind of covert on the Continent. I think I am warranted, therefore, in saying that the name hazel grouse is a misnomer. Be this as it may, there is no doubt that the bird is nowhere found on open moorland, and therefore could not ever "rival" the red

${ }^{1}$ Sand-grouse are, by some authorities, not classed among true grouse. 
grouse of Scotland. Even black-cock ground is not suited to its habits; and it would be far more likely to be at home in pheasant coverts, which are found throughout the British Isles.

Noteworthy it is, too, that both of our writers speak of its great table qualities. I do not agree with Mr. Burton's friends, who call the hjerpe the best eating of the grouse tribe. I have always held that a cold Scottish grouse and a bottle of Burgundy is a lunch for the gods, and this toothsome stranger shall not oust our older friend from my gastronomic affections. But the hazel grouse, as I have shot him, in wintry woodlands, is excellent eating, and, according to Sir Henry Pottinger, the plentiful diet of wild berries to be obtained in a Norwegian autumn gives an exceptional 
flavour to all kinds of game. The hazel grouse is also a peculiarly handsome bird. I know no wing more effective in a lady's travelling hat than his, save, and except, that of the painted snipe. The colouring of the breast and sides is very beautiful and would make lovely trimming, and even the loose feathers thereof make a collar or boa much handsomer, to my mind, than the dyed things sold in shops. But now it is time to look at the other side of the picture. I have found the hazel grouse exactly as described by Sir Henry Pottinger. Rarely, indeed, does he rise at one's feet, and if he does, he is off through the thick branches like the proverbial "shot out of a shovel." A woodcock in covert is a fool to him. But follow him up noiselessly, and presently you will become aware of your game, un- 
mistakable by its triangular head (the crest gives it this appearance), quietly seated, though with every sense alert, on the limb of some tree. Then if the pot is empty, or the camp menu requires variety, you will "down" him ruthlessly, as Sir Henry advises. Being, however, as you may be, a beginner at the game, you endeavour to approach nearer. All at once the bird is gone! You heard the whirr of his wings, but you saw nothing, for he kept the big beech tree between you and him. With beaters it is another matter. If the guns are posted in the wood itself, and that wood be fairly opena beech wood, for instance-you will get shooting, and every bird killed will send a virtuous glow down your back. But I venture to prophesy that there will be a 6 
great many more empty cartridge cases than birds.

Now we can cast up the merits of the bird, and weigh the pros and cons of the matter. In favour of acclimatisation we have-(I) That the bird is calculated to thrive in British woodlands; (2) that he is excellent eating; ( 3 ) that he can afford good sport if he alone is the object sought for; (4) that he will never stray from the woodlands; (5) that he will never do any damage to crops.

Against him we must urge-(I) That in covert shooting, as now arranged, not one of these birds would ever come to the gun; (2) that where they were systematically shot, as I have above indicated, the pheasants would be greatly disturbed and driven off. 
From this we may sum up that the hazel grouse is very suitable to certain landowners and shooting tenants, and specifically to those $(a)$ who have coverts given up to rabbits and occasional cock, but free of vermin; (b) who cannot preserve pheasants because the covert is on the boundary, and the birds are led away by corn crops, etc.; and (c) those who find the big stupid pheasants impossible to preserve if they are ever to be at peace with their neighbours. Those living near collieries, mines, or factories will know what I mean. The pheasant is certainly a great temptation, but the hazel hen, active and woodloving, will, I think, prove a difficult nut for the night poacher to crack. Day poaching with the gun can easily be kept down. 


\section{4}

THE HAZEL GROUSE

Lastly, how to get the birds? Well, any continental game-dealer should be able to supply, or some of those agents who advertise Norwegian shootings.

I only hope that this article will induce some landowners and shooting tenants to try the experiment. I, for one, intend to do so as soon as I have the opportunity. It is, however, only right to add, that all my attempts to purchase a few couples of live hazel grouse have hitherto failed. I have, however, not had any opportunity to try Scandinavian dealers. 


\section{SPORT IN SHAKESPEARE}

THE allusions to the pastimes of his day 1 in Shakespeare's plays are so endless that I propose to avoid them altogether, and to confine myself to those which refer to our most prominent field sports. Hawking, of course, was the principal one of that day, but I do not propose to enter into that either, because so few of us know anything about it nowadays.

Shakespeare certainly was a sportsman, or he could not have written as he did; and it 
is a pleasure to think that his boyish raid on Sir Thomas Lucy's deer at Charlecote was inspired, not by any desire for filthy lucre, but by the feeling so well expressed in the old song-

"For it's my delight on a shiny night

In the season of the year."

Probably the best known allusion to hunting in Shakespeare is that in the Micsummer Night's Dream, where Theseus describes his pack thus-

"My hounds are bred out of the Spartan kind, So flew'd, so sanded; and their heads are hung With ears that sweep away the morning dew;

Crook-knee'd and dew-lapp'd like Thessalian bulls, Slow in pursuit, but match'd in mouth like bells Each under each. A cry more tuneable Was never holla'd to, nor cheer'd with horn."

An irreverent modern sportsman might say that there was probably more cry than 


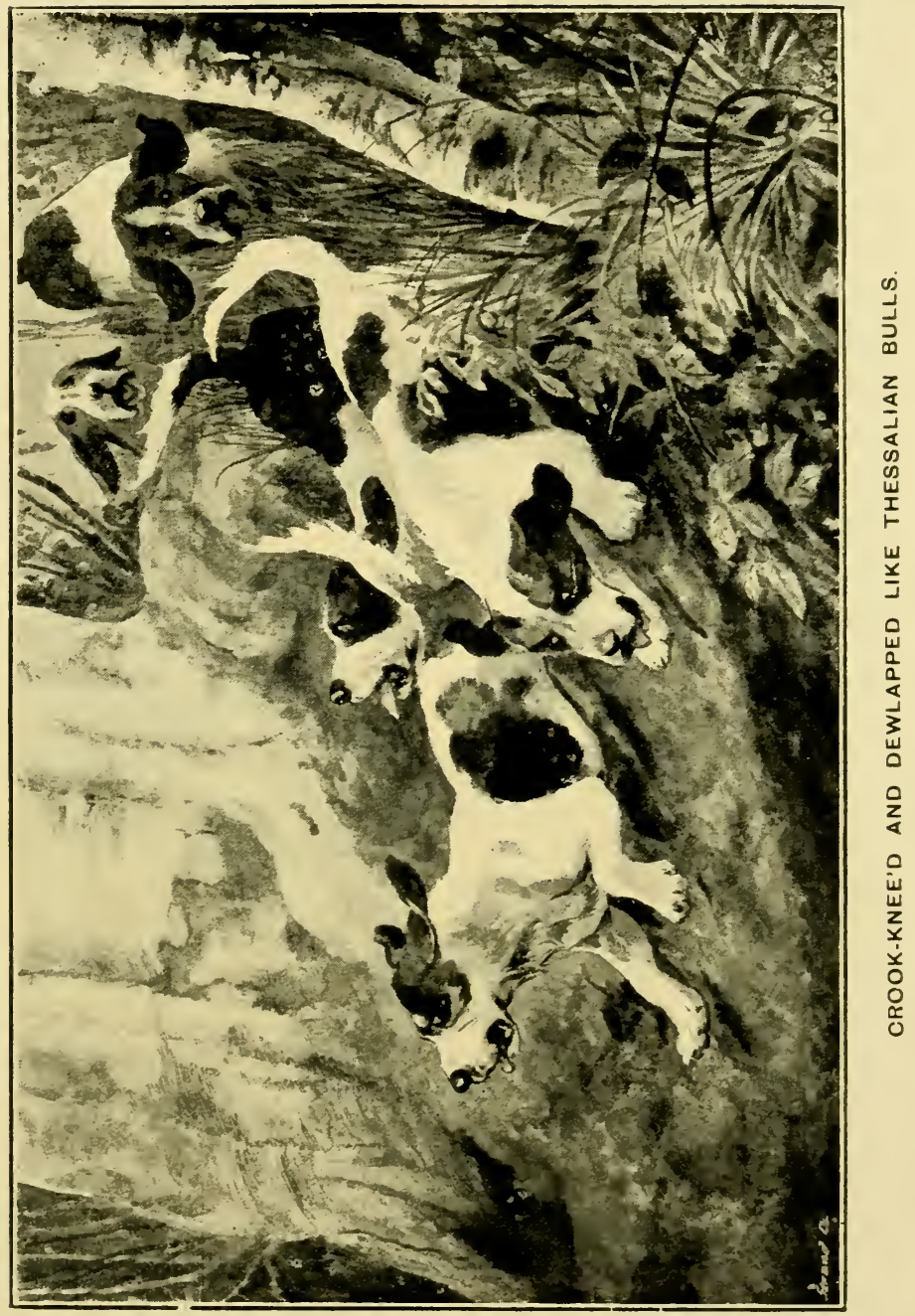




\section{SPORT IN SHAKESPEARE 87}

wool_or rather fur-with such a pack. I confess I have often puzzled over this passage, and wondered what kind of hound the writer could possibly have had in his mind's eye when he penned it. Had the quotation been a modern one, I should have said that it was a perfect description of a pack of French bassets-à-jambes-torses, such as I once had the pleasure to be a master of ; but we know that this is a modern breed, being the result of a cross of the dachshund with the long-eared French breeds, such as the Arras. It is said, indeed, to date no further back than the Restoration of ' 15 , and to be due to the emigrés, who brought back the crook-kneed breed from Germany. Be this as it may, I do not believe the basset existed in the days of Queen Bess. I know it has been said that the old English bloodhound 
was a crook-kneed animal, but I do not believe this either. The idea possibly arose from the representation of some animal deformed by "rickets," for that this can occur with stray specimens of any breed is to my mind as certain as that the dachshund's formation is not so produced. This is one of the original varieties of the genus canis, in proof of which statement, Assyrian sculptures and Egyptian paintings can be adduced.

'The passage which to my mind proves that Shakespeare knew a good deal about hunting is the following one from the Taming of the Shrew, which could undeniably only have been written by a hunting man and a "houndman "-

"Lord. Saw'st thou not, boy, how Silver made it good At the hedge corner in the coldest fault? 
Huntsman. Why, Bellman is as good as he, my lord, He cried upon it at the merest loss, And twice to-day pick'd out the dullest scent.

Lord. Thou art a fool; if Echo were as fleet, I would esteem him worth a dozen such."

Here we see nose and pace valued just as much as we value the union of those qualities now; and it is worth observing that these lines occur in a play of no assigned period, whereas we can easily understand the writer putting into the mouth of Theseus such ideas as he might conceive to have been entertained by a sportsman of ancient Greece, however far removed from his own.

To coursing there are fewer allusions in our author, though greyhounds are referred to several times. In The Merry Wives of Windsor, Slender asks Page, "How does your fallow greyhound, sir? I heard say he was outrun on Cotsall." Page's answer is : 


\section{SPORT IN SHAKESPEARE}

"It could not be judged," which I take to mean that the fallow dog had run an undecided course.

Of shooting, both with the long and crossbow, we have, of course, plenty. In Love's Labour Lost we have an accurate description of deer shooting as it was practised, amongst others, by Queen Elizabeth, but we are not told if the deer killed by the Princess was driven past her by dogs or beaters. There is also an amusing dispute between Sir Nathaniel and Holofernes as to whether it was "a pricket," i.e. a three-year-old, or "a buck of the first head," that is, a five-year old, or, as we say nowadays, in the New Forest, "a warrantable deer."

In that woodland drama As You Like it we have, of course, a good deal about deer shooting, but nothing especially worth 


\section{SPORT IN SHAKESPEARE 91}

quotation. Looking up the play in question in Knight's Pictorial Shakespeare, I find the "sequester'd stag" represented as a fallow buck, and one of "the careless herd," resembling more than anything else an American black-tailed deer - two singular inaccuracies in one engraving. But all the drawings of deer given in this play are open to criticism. The description of the conduct of the herd of red deer towards a wounded companion may be true to nature, but most animals show considerable consideration to a wounded nember, and generally wait and look back for him after the first rush a rifle report produces. 


\section{VII}

\section{WHICH THE YOUNG SPORTSMAN MAY READ WITH ADVANTAGE}

WHEN I was a bit of a boy I read somewhere that "to get the best results with a cartridge the shot should be tightly packed with sand." I took the hint. "Shutin's a quare thing nowadays," said an old labourer of ours at the harvest-home supper not long afterwards; " $t$ 'other day I picked up one o' these yere cartridges some genelman had dropped, and, thinks I, I'll just see what's in this chap; so I cut 'un open with 
my knife, and, dang me, if he weren't half full of jackstones!" Let me now do what I did not do then, and confess that the cartridge was mine. The "jackstones" were the coarse sand I had packed my shot with. But it was a long time before I got to see the real cream of the joke. The "cartridges" to which the sporting writer referred were wire cartridges for wildfowling!-not, of course, the ordinary "shells," to use the Yankee term. The only result of my loading could be to reduce the shot charge, and perhaps scratch the barrel of the gun. "A little knowledge is a dangerous thing." . . . I had intended to multiply examples of this sort of thing, but as I cannot possibly beat the above I think I will leave it "to point a moral and adorn a tale." 


\section{VIII}

\section{ON DACHSHUNDS}

" B Y this decision," I read in the Shooting Times report on the Leicester Dog Show, "it is apparent that a dachshund, however great a cripple he may be, is not disqualified from winning prizes."

It is not my object in this paper to discuss the points of dachshunds, so I will briefly say that with me it is a sine qua non that a dachshund's foreleg in profile should be as straight as a foxhound's. The peculiar curved shape should only be visible from the 
front, and I do not believe that any dog so built can ever be a cripple-I mean from causes of formation. But my object does remotely bear on this point, because it is to try and convince a few English sportsmen that the dachshund is a sporting dog. If he is, as I think I shall presently very clearly show, it is obvious that he cannot belong to that class of $\operatorname{dog}$ in which it is not any drawback to be a cripple. But the ideas of English people on the subject are really very funny. The other day I saw a dachshund advertised in the Field by a sporting publican. "Can go a good bat when roused," it ran, as if the owner was really quite surprised it could do more than waddle.

I should be sorry to be (foot) huntsman to a pack of dachshunds. When I was Master of a pack of basset hounds, I for 
some time ran a dachshund of mine with them, but found him too fast for them. This is no criterion of speed, I grant, and a dachshund is not, and should not be, a fast dog; but he should be a quick, active dog, and go along on a scent at the rate, at least, of a twelve-inch beagle.

Now let us analyse the dachshund's claim to be considered a sporting dog. I base that claim on three grounds-(I) His position in his native country, (2) his uses in this country, and (3) my own personal experience of him in many countries.

And first as to his position in his native country, by which I mean Germany and Austria, where he has so long been naturalised, for the real land of his origin has long been lost to human knowledge, even if he is not, as I said in a previous chapter, one of 


\section{ON DACHSHUNDS}

the original breeds of dog. At all events, as there stated, we find the dachshund in Babylonian sculpture and Egyptian frescoes. In Germany and German-speaking Austria, the dachshund is the keeper's dog par excellence, and one seldom meets a förster or waldhiiter who has not one trotting at his heels. This alone should prove him a sportsman's dog, for a keeper is not a likely man to keep cats that cannot catch mice. Well, what does he use him for? First and foremost, he uses him for the destruction of vermin. In autumn, when the badgers are fat, he expects him to lie up in the badger's earth till both are dug out. He also uses him to bolt the fox, for which he waits with ready gun outside the earth. Or he will slip a couple of dachshunds into a small close covert while he covers the most likely place 
for the fox to break. Secondly, he uses him as we do beagles in Scotland, to drive roe to the guns; but this is not done everywhere, as harrying with dogs is apt to make roe shift their quarters. Red and fallow deer are also thus killed; or wounded, when the dachshund, on a line, is used to track the stricken beast to his last lair. In wild boar shooting, again, the dachshund is used in two ways. If a single dog is used, the boar will stand to bay, and the dog's bark directs the sportsmen where to steal in and get a shot. Two sportsmen approaching from opposite sides have a still better chance. Or, if two or three dachshunds are used, they will drive a boar to the guns previously posted every whit as well as larger dogs. To show that the dachshund is looked upon only as a sporting dog in Germany, it is only necessary to 


\section{ON DACHSHUNDS}

mention the field trials held in many places, where prizes are given to the best dachshunds (in various classes) at bolting foxes and badgers from scientifically laid-out earths.

I now come to his uses in this country. First and foremost, dachshunds entered young make a pretty, handy, and smart pack of beagles. The only difficulty, to my mind, is to get them musical enough, but they can be found so in Germany, and, for aught I know, in England. English dachshunds will do very well for this purpose, for the bassetcross which must have been used to get the position of the ear. our judges go for (and which also brought the prominent shape of the back of the skull, the weak, snipy jaw, and the want of pluck generally found in English dachshunds) is no drawback here. 
Secondly, they can be used in England as in Germany for badger digging, and in Scotland and other non-hunting countries for bolting foxes to the gun. But their more general use will be rabbiting and covert shooting, where there is not much game-rough shooting, in fact. I habitually use them so, and it is not necessary to say more than that they must be taught to go with the keeper, or beaters, whereas they prefer to accompany their master with the gun. German authorities insist that the dachshund must be trained to come to whistle, even if on a hot scent. Mine, I fear, are not broken to this canon, and I admit that it is rather trying to hear an old cock pheasant go sailing away far out of shot after five minutes' full cry. This drawback, however, applies equally to covert shooting with beagles, and sometimes 
the same thing happens with cocker spaniels. It is, after all, a mere question of training. I have often shot partridges over dachshunds, and had some dogs that would road a covey steadily a field or two. In roots they are capital when kept in close, and will find and put up every bird of a scattered covey. They could certainly be taught to retrieve. I have a bitch now that finds and stays beside every lost bird, but is too old to learn to fetch them. My German friends, who are great sticklers for the traditions of sport, tried to make me see that it was not "correct" to shoot partridges over dachshunds. One of them asked, at the very moment I had a couple busy in the beetroot field we were crossing, "What would you do if a hare got up?" "Why, that," I answered, rolling one over which the dogs put up. 
The answer came pat ; but it must be admitted that if she had gone away, several coveys might have been flushed. The proper answer is, "Break them to come to call, whether on a scent or not." I do not do this for a specific reason, which is that my dogs are expected to go with me to certain happy hunting-grounds I wot of, where the roe-deer lie in great woodlands; and experience has shown me that, in order to get them to draw wide, and hunt till they bring their deer to the gun, they must be trained as hounds, that is, entered to game, but not broken.

As to my third head, I have, I fear, encroached on it already in the last one. Suffice it to say, that in England I have shot over dachshunds all our native game except grouse; and abroad, chamois, roe, 
foxes, jackals, wild boar, and many kinds of winged game. To show what a dachshund will do, I may mention a little bitch I took with me on the trip to Albania, described in another chapter. She had only one evening to make the acquaintance of our skipper, but nevertheless when told went readily with him and the huge Albanian dogs. All day she hunted roe, pig, and jackal till, in the evening, she could hardly crawl, and her ears were perfectly hairless. (Those who have been to Albania know what the thorns are there.) Next day we left her on the yacht, and on the third day she was as ready as ever, and worked all day. Ground and beaters were quite strange to her, and she had never hunted any furred game but hares, and those more than a year before this. Was this not a 


\section{O4 \\ ON DACHSHUNDS}

sporting $\operatorname{dog}$ ? and what use would a cripple have been in such a country? I have known my dachshunds follow chamois along paths on the face of sheer rock many hundred feet high. Could a cripple do that ?

As for the non-sporting side of the question, the suitability of dachshunds as companions, I think there can be only one opinion, but that it is entirely beyond the scope of this paper, which I will close with a story told by Herr Corneli, a name familiar to many Englishmen. He lost his two dachshunds in the woods one day when out fox-shooting. Five days after, a woodman came, and said he had seen one crying at the mouth of a fox-earth. Going to the spot, he found one dog, and digging into the earth the other, safe and sound. This dog had followed the fox in, but a falling rock had 


\section{ON DACHSHUNDS}

barred his exit, so, after killing the fox, he had lived on him, having eaten all but the head and the brush. Meanwhile, his companion had stuck by him, fasting five days in order to do so. One hardly knows which to admire most-the pluck of the one dog, or the fidelity of the other one to him. 


\section{A RECORD}

\} { } ^ { \mathrm { E } } \text { were a small but cheery party } staying at the White Horse, at

Exford, ten years ago, for stag hunting. The off-days were rather tedious, and the youngsters of the party fell back on whipping the Exe and Barle for trout. One Sunday morning a little knot of us were hanging about on the bridge, when the conversation turned not unnaturally on a fish that for days had been persistently lying just above the arch.

"I think I could get that fellow," I 



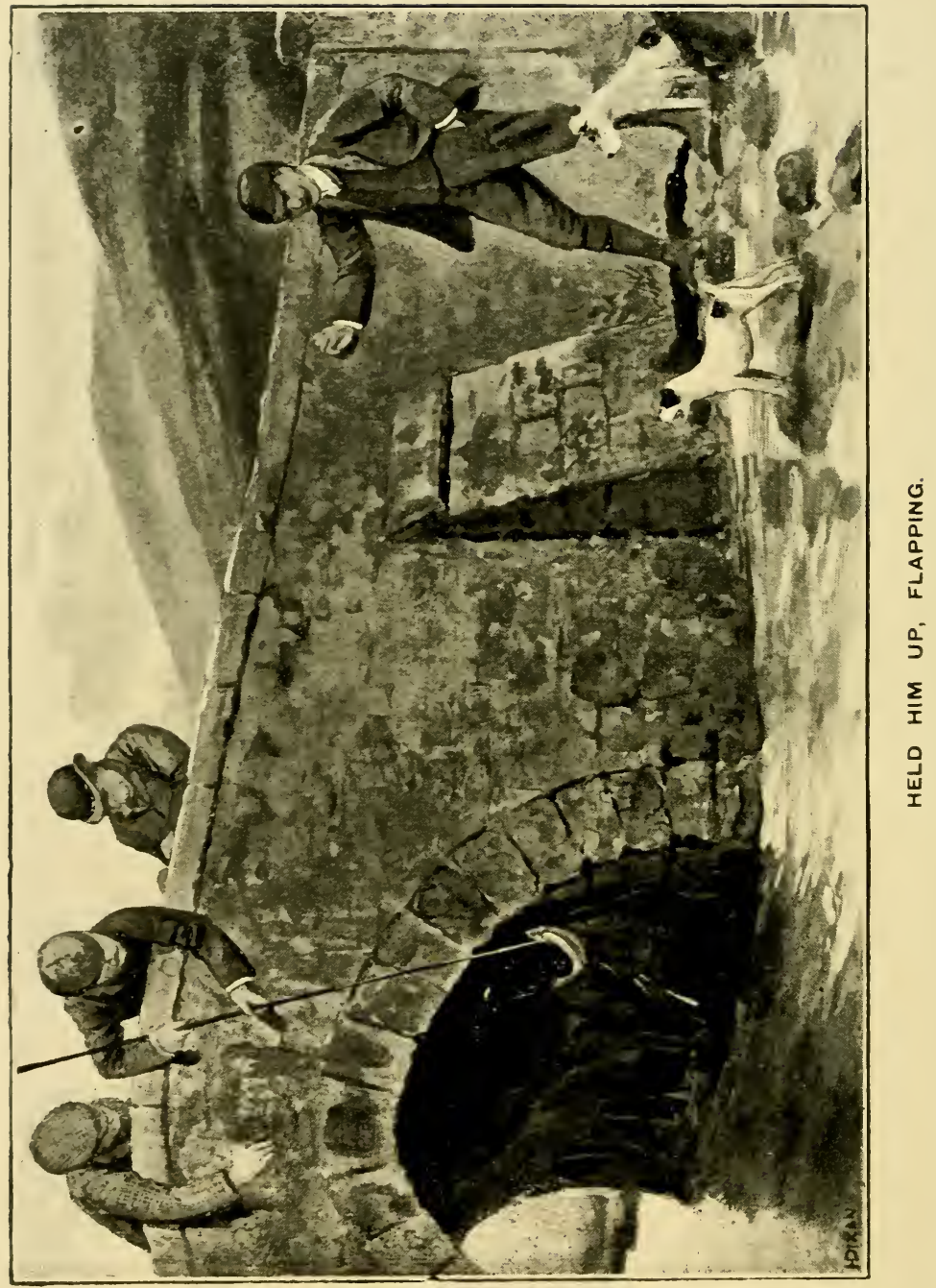




\section{A RECORD}

remarked. Being challenged to do so, I borrowed a rod, and, removing the top, tied a hook about two and a half inches long to the end of the next joint. I am not an angler, but, schoolboy recollections helping me, at the second attempt I neatly "snatched" the fish, and held him up, flapping, in triumph. Oh, horror! it was not a trout at all, buta salmon pink!

"Well, for a county magistrate I think that's a record," quoth the late Colonel —. himself the Chairman of a Bench, when the laughter occasioned by my exploit had somewhat subsided. "Let's see how it would work out on a charge-sheet :--

“( I) Taking salmon in close time (Sunday).

“(2) Taking salmon pink.

“(3) Taking salmon without a licence.

“(4) Taking salmon with an illegal engine. 
“(5) Fishing in the Exe without a ticket."

Unfortunately the unhappy salmlet was not in a condition to be returned to the water, but the lesson-not to meddle in sports one does not understand-was not wasted on me. I have never caught a fish since, though I once did (in France) shoot a carp with a rook rifle.

Fortunately my case never came before any Bench, but I remember one which did, and which ran it pretty close. It was that of a youth who shot a swan on the Lower Wye. He was charged with

(I) Carrying a gun without a licence ;

(2) Infringement of the Wild Birds Protection Act ; and

(3) Trespass in pursuit.

Moreover, when he had finished at the Police Court, he was summoned in the 
County Court for the value of the bird, by the Corporation to which it belonged.

I should say next time he wants a swan he will go to Leadenhall Market. 


\section{$\mathrm{X}$ \\ "TRADE BULLETS"}

M $\begin{array}{r}\text { OST sportsmen who do any amount } \\ \text { of big game shooting must have }\end{array}$ experienced some unaccountable results in the getting away of game where they have felt sure of their shot, and even where fairly extensive bloodmarks show that the aim was not to blame. It was such results as these which made me fly to big bore rifles, and so sacrifice range and trajectory rather than smashing power. Some years ago a re- 
viewer took me to task for speaking of a .500 Express as a pop-gun, but when I explained that I meant with a hollow fronted bullet, he expressed himself satisfied-which he ought not to have been. Since those days I have made a series of searching inquiries into rifles, and especially ammunition, and I believe that I have at last got to the root of the matter. At all events, except for elephants (and perhaps bison) in jungle, I am willing to renounce the $4, S$, I 2 , and 16 bores for the future. The .577 Magnum, which is 20 bore at the breech and practically 24 in the bore, is big enough for anything else-perhaps even for these. I speak of the "bottle" case, but the $3 \frac{1}{4}$ in. straight is, of course, equally effective. But such weapons are hardly those which are in use by the ordinary game shot, and I 
refer to those which might be required in Scotland.

The reason, I believe, that there are so many of these unaccountable failures to bag with the rifles in common use is simply want of "drive." What is the secret of the tremendous outcry made (mostly in South Africa) in favour of the .303 as a sporting weapon? Not, I think, as much low trajectory or high velocity as the fact that with these weapons either a solid (compound) bullet is used, or, at all events, one with a long solid base.

Now let us look at the ordinary, or " trade" bullet supplied by gunmakers. We will take the .500 as being perhaps the most useful all-round rifle, and certainly that in most general use. If we examine the 340grain bullet, as generally sold, in section, 
we find that it has a hollow, $\frac{1}{8}$ in. in diameter, in the centre, the walls of which hollow are but $\frac{3}{8}$ in. thick at their broadest, and consequently expand or fly to pieces directly they strike a bone. Then what is left to penetrate the animal is a wad-shaped piece of lead $\frac{1}{4} \mathrm{in}$. thick. Examine the shoulder of a dead tiger, and then ask yourself what this is to penetrate that mass of sinew, muscle, and bone. This is the secret of these failures, and it applies chiefly to the bores most in use-the .500 and the .450, the "trade" bullet, of which latter is only 270 grains. The 400 is a little better, as its bullets are 230 grains, with a seven-sixteenths inch base; but I propose to return to this bore presently.

Of late years some gunmakers have awaked to these facts, and supply a 325 8 
grain hollow front bullet for the .450 and a 440-grain hollow front bullet for the .500 . Now, it seems to me that they thus avoid the Scylla of bullets with too light a base, only to fall into the Charybdis of getting a bullet too heavy for the powder, or, in other words, a high trajectory. I say "it seems to me," because I have not been able to make the necessary experiments to prove or disprove my idea. I imagine that for these heavier-based bullets it is better to adopt the so-called Magnum chambering, having 140 grains of powder in .450 and 160 in the .500 ; but I leave it to gunmakers to consider whether they cannot give us the lighter bullets in a different shape, so that we may have a heavier base and yet the same weights of powder and lead respectively. Meanwhile, sportsmen are warned that all 


$$
\text { "TRADE BULLETS" }
$$

ordinary ammunition made by the larger firms of ammunition makers for use in .450 and .500 bore Express rifles contains these "trade" or, in plain English, ineffective bullets.

I said before that I would return to the subject of the .400 bore Express-my latest love in rifles. In this bore the "trade bullet" is 225 grains, with a base seven. sixteenths of an inch thick. Behind this is So grains of powder, or in a Magnum i Io. A better cartridge is the American Winchester express, also made by Eley, with IIO grains powder and a 260-grain hollow-fronted bullet.

An English firm has recently attempted to get better results in this bore in what they call the $.400-400$ rifle, the first number referring to the calibre, and the second to 


\section{16}

"TRADE BULLETS"

the weight of the solid bullet used therewith. They also supply two hollow-fronted bullets weighing 340 and 370 grains respectively. In this latter the hollow is only five-twelfths of an inch deep, leaving a solid base over an inch long. This is no cloubt a splendid projectile, but it has unfortunately the great drawback that an enormous charge of powder $^{1}$ is necessary to give it a satisfactorily flat trajectory. The .450 Magnum, of which the bullet weighs only 325 grains, is found to require 140 grains of powder, so that a 370 grain bullet would require about I 60 grains, which the 400 case will not hold.

1 Black powder, of course, is referred to throughout this article. I have no doubt the $.400-400$ rifle with a charge of 42 grains of smokeless powder would give excellent results. But, as all sportsmen know, there are objections to the use of nitro-compounds in wild countries, to go into which would, however, be beyond the scope of these remarks. 
But taking even the lightest bullet of this make-340 grains. From practical experience I know that the trajectory of the Winchester .400- I I C-260 is only moderately flat. What sort of a trajectory can we then expect with a bullet $\& \circ$ grains heavier, the powder charge being constant? Moreover, so heavy a bullet would increase recoil, and together with the use of the bottleshaped cartridge case, for which these rifles are made, be very trying to any ordinary rifle action.

Being thus dissatisfied with every .400 cartridge made, I turned my attention to the possibility of devising one which should, as far as possible, combine the advantages and avoid the defects of all. Preferring, as I (and most practical sportsmen) do, a tapered case to a bottle-shaped one, because it throws so 
much less strain on breech and action, I was restricted to the Eley (or Winchester) $3 \frac{1}{4}$ in. case, which is the only tapered .400 case made, so far as I know. This case is usually loaded with I IO grains powder, and the Winchester 260 grain bullet with a half inch hollow at the point. Now what are the faults of this cartridge? I consicler them three - First, the proportion of lead to powder is excessive, giving comparatively high trajectory; second, the bullet (260 grains) is fully light for the larger deer, etc., and consequently deficient in shock; and, third, the hollow at the point of the bullet is too deep, and is filled by a copper tube, which I know from practical experience impairs its expanding qualities, causing it to go right through an animal, making a clean wound and little blood, 


\section{"TRADE BULLETS"}

In my cartridge (which I have ventured to call the "Snaffle" cartridge) I have combated these faults as follows:- The first by increasing the powder charge by oneeleventh and the lead by one-thirteenth, thus lowering the proportion of the latter to the former; the second, by increasing not only the weight of the bullet, but the length of its solid base; and the third, by leaving the hollow at the point, now reduced to a quarter of an inch, quite empty. The "Snaffle" cartridge can thus be best described as a .400-I 20-280, whose bullet has a hollow a quarter of an inch in depth at the point, with a tapered case. Its advantages seemed to me so evident that I had some loaded at once, and am more than satisfied with the result. Before coming to this I will tabulate the loads, etc., of all the .400 bore rifle 
cartridges made in England, with my own, so that the reader may see at a glance the merits and defects of each.

\begin{tabular}{|c|c|c|c|c|}
\hline $\begin{array}{l}\text { Name of } \\
\text { Cartridge }\end{array}$ & $\begin{array}{l}\text { e of } \\
\text { idge }\end{array}$ & $\begin{array}{l}\text { ler Charge } \\
\text { Grains }\end{array}$ & $\begin{array}{l}\text { Bullet } \\
\text { Grains }\end{array}$ & $\begin{array}{c}\text { Cartridge } \\
\text { Case }\end{array}$ \\
\hline Eley & . & 80 & 225 & Bottle-shaped \\
\hline Eley & . & IIO & 225 & do \\
\hline \multicolumn{2}{|c|}{ Eley's Winchester } & I IO & 260 & Tapered \\
\hline \multirow{3}{*}{\multicolumn{2}{|c|}{ Jeffery's $\cdot 400-400$}} & I 10 & 340 & Bottle-shaped \\
\hline & & I IO & 370 & do \\
\hline & & 100 & 400 & do \\
\hline Snaff & . & $120^{1}$ & 280 & Tapered \\
\hline
\end{tabular}

From the above table it will be seen that in my cartridge there is the heaviest bullet with which the due proportion of powder to lead is at all observed; that the trajectory is low, that the shock is great, that the open hollow must expand on impact, leaving a

${ }^{1}$ If preferred, to give still flatter trajectory, the loader may be told to fill the case, which, leaving room for the bullet, holds 123 to 125 grains. 
heavy base to drive it home; and that the case is tapered, not of the objectionable bottle shape. Given all these advantages it must, I think, be conceded that it is the best all-round cartridge yet designed for all ordinary game.

After all, "the proof of the pudding is in the eating," and here is a representation of the first "Snaffle" bullet ever fired at game.

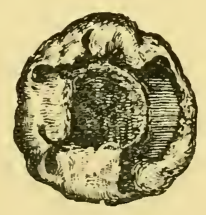

It was fired at a chamois, moving away at about I 30 yards distance. The tremendous shock fairly knocked the animal forwards, and after going a few yards it died. The bullet struck between the ribs and hindleg, and was found by me under the skin of 
the throat. As will be seen, it is nicely "mushroomed," with a good solid base to drive it through. I have not yet had a chance to use these cartridges at anything bigger than chamois, but it simply crumples them up with an absolutely flat trajectory to a hundred and fifty yards or so.

Since writing the foregoing I have made arrangements whereby the "Snaffle" cartridge (regd.) can be obtained solely from Mr. W. R. Leeson, the well-known gunmaker of Ashford and 29 Maddox Street, W., and as I have no pecuniary interest in its sale, I may say I hope some of my readers will give it a trial. 


\section{XI}

\section{OLD COACHING DAYS IN THE LAKE DISTRICT}

A RECENT reference in a sporting District, brings vividly back to my mind the many jolly days I spent on the road thereabouts during the seven years I passed at Windermere College.

What a dear old place it was! and how many pleasant memories of boating, bathing, birdnesting, skating, hunting (on foot), cricket, and mountaineering does the name 


\section{I24 OLD COACHING DAYS}

bring back? But it was principally the last two that were connected with coaching recollections. Cricket in those days was the only idol of a schoolboy's worship. There was no tennis then, and football, which we played in winter, of course, was not by any means the passion it has since become in the north. The school boasted six minor clubs, through which every boy had to work his way to his final promotion to "the Eleven." This was no mean one, for in those days it could hold its own in the north of England, and such clubs as the Walton and Sefton were glad to come from Liverpool, and try conclusions with "the boys," who, of course, except in school matches, played their professional.

It was to many of our "out" matches that our coaching trips were mạde. Burton-in- 
Kendal was one of these, and there we played in Mr. Hornby's park, and he mostly captained the Burton team. A still longer drive was to Kirkby Lonsdale, where Lord Bective was our host at Underley Park. A sad memory is connected in my mind with this, for about my last trip there, one of our non-playing comrades was drowned, while bathing in the Lune.

It was on these occasions I first had the chance of handling a team. One or two of our masters drove a bit, and we who were used "at home" (how the old schoolboy phrases crop up!) to handling a pair, generally got a chance of "tooling them." In fact, the driving was my inducement for going on these occasions, for my cricket was never up to "eleven" form. I generally managed to go, however, as scorer, umpire, 


\section{OLD COACHING DAYS}

or guest. These coaches were owned by John Rigg of the Windermere Hotel, who then had, and I believe still has, the contracts for the mail coaches - of which more anon. Our usual driver was an old professional called Bell, a fine whip, but, truth to tell, sadly intemperate, for which offence he had been many times discharged and afterwards forgiven by his master. I well remember the episode which led to his final discharge. A couple of coaches had been chartered to take a lot of us to Keswick for a climb up Skiddaw. At the last moment the accommodation proved insufficient to seat us all, and Rigg sent down a pair-horse brake to take the rest. Bell was the driver of this. While we were climbing he was drinking. Coming home he could hardly sit on the box without help, 
but he obstinately refused to give up the ribbons. The lamps had been lit at Rydal. I was on the second coach, the brake bringing up the rear. Not half a mile from Ambleside we passed a waggonette returning to Grasmere empty. Bell was on the wrong side of the road; and, looking back, I saw by his lamps that he was not pulling across, in spite of the other driver's shouts. The result was a smash, but, strange to say, the two pole-heads met fair. Bell's shivered, but no other harm was done. Of course, we had pulled up, and, by the way, it was Bell's son that was with us-one of the masters driving at the time. The old man was forcibly removed from the box and shut up inside the son's coach. Finally they drove off, leaving me to drive the brake home, for which purpose they promised to send me a 


\section{I2S OLD COACHING DAYS}

pole from Ambleside. Some time elapsed before it arrived, and though I sent the old post-horses along, all I knew, they were too tired to make much of a pace up the Troutbeck Hill. When we reached home the coaches were gone, and an ostler was waiting for the brake. As luck would have it, Mr. Rigg had noticed the long interval between the two arrivals, and came out to question Bell. Of course, he noticed the lad who was driving, and further investigation-discovering the strange pole, and lastly Bell himself, still snoring inside the coach -resulted in prompt and final dismissal. Otherwise, the matter would probably have been hushed up, as the old man was a general favourite, and his son, who I believe is still driving, a steady fellow and a smart whip. 
In relating this episode I have rather mixed mountaineering with cricket. As has been seen, several coaches used to take us to the beginning of our climb-say Coniston for the "Old Man," and await our return to take us back, after a substantial tea. My favourite trip was Helvellyn, for there the coaches used to drive us to the Patterdale side; and, while we went over the Striding Edge and down by Thirlmere, they used to drive round by Ambleside to meet us at Grasmere. My proceeding on these occasions was to "stow away" and then, reappearing on Bell's coach, drive all the rest of the way to Grasmere. I have a vivid recollection of one day's drive. It was to Dungeon Ghyll-the mountains to be tackled being the Langdale Pikes. Before we reached Troutbeck, Bell had 9 


\section{OLD COACHING DAYS}

given me the ribbons of his (the leading) coach, and taken the brake seat.

Just before we reached Lowood Hotel, a blind turn showed a wood-waggon half across the road. The driver was away, probably nutting, and the road on the lake side was unfenced. We were coming smartly down hill. "Take his wheel off, sir," quoth Bell coolly, at the same time taking off the brake. W'ith a shout at the leaders, I double-thonged the wheelers, and, probably more by luck than anything else, took his near hind-wheel just inside the felloe with my off one. The shock was scarcely perceptible to me, but, as Bell had calculated, it was too great for the rusty old linch-pin, and the wheel actually followed us some way down the hill. The cart-horses only gave one frightened movement, so I was 


\section{IN THE LAKE DISTRICT}

told. Of course, these pleasure coaches, like the mail ones, were old-fashioned, and very strong and heavy. I shouldn't care to make the experiment with a drag.

To return to our drive. After leaving Waterhead, one of the masters, a young fellow with spectacles, took the ribbons. He succeeded in jamming his near-side wheels against a stone dyke, which cleared the coach-roof, sending most of us over the wall into the field beyond. However, no harm was done. I will say for the driver, that a nastier road than this same Dungeon Ghyll one was then hard to find. Our troubles were not over yet. At the bottom of this hill, the near-leader, a grey mare, who was in use, started kicking, and somehow broke the main splinter-bar. We carried no spare ones, so all we could do 


\section{${ }^{132}$ OLD COACHING DAYS}

was to take her out and send her on by a yokel, and finally I drove up to the Dungeon Ghyll Hotel with a pick-axe team. But even this was not all. All we could borrow to replace the broken bar was a plough one, of course, without spring-catch. The opening of this was secured with stout string; and so we started for home. Going down a celebrated nasty hill, the name of which I forget, the hook came out, and down dropped the bars right under the wheelers' feet. Bell was fortunately driving, and completed the descent without stopping, keeping his leaders away in the most wonderful manner. This was our last accident that day.

My experience of the road coaches was more limited. As far as I can recollect, there were originally three, all annual and 


\section{IN THE LAKE DISTRICT I33}

all hailing from the Windermere Hotel. The first ran to Ambleside, Rydal, and Grasmere to Keswick, an easy road. The second ran by "the highest inhabited house" down Kirkstone Pass, a nasty dangerous hill, to Ullswater and Patterdale. These two still run-at least, I drove the latter during a flying visit to the old place (no longer a school) in the Jubilee year. The third, which may be run now, but was, I fancy, at one time taken off, ran by Bowness and, crossing Windermere Lake by the ferry-boat, reached Coniston through Hawkshead. This road presented no difficulties, but the ferry required a steady team. It was not a steam affair in those days.

I have already described the coaches. The horses were the pick of Rigg's posters, 


\section{I34 OLD COACHING DAYS}

heavy on hand, not too fast, or, perhaps, too sound, but capital practice to drive. Did I drive, or only hear of, one celebrated team there that had only three eyes amongst them? I forget.

What I do recollect was working the Keswick return coach into Grasmere one day in time to hear the news of the Tichborne claimant's conviction, over a score of years ago. 


\section{II}

\section{THE FINEST SPORT}

QUESTION that has been put to me A more than once is the following:"You have a good deal of all-round experience, what do you consider the finest sport?" And a very difficult question it is to answer. In the smoking-room, of an evening, the finest sport is generally that which we have that day been enjoying, whether it happens to have been a quick thing with the Blankshire, a big day at the rocketers, "as high as they make them," a productive tramp through 


\section{I36 THE FINEST SPORT}

the heather, a long and tiring grind after a "warrantable stag" across the hills and combes of Exmoor, hours spent, tiller in hand, with one eye, so to say, on the mark boat and the other on the leash of the straining mainsail, or, no doubt, half an hour's struggle with a $20 \mathrm{lb}$. salmon, though of this last only I cannot speak from experience.

Some sports seem to single themselves out for comparison,-_for instance, pig-sticking and fox-hunting, - a comparison which I, personally, would never make, having a perhaps weak-minded way of attaching myself to my horses; and though, no doubt, it is a fact that we do risk our favourites a score of times in a quick run, even over a moderate country, still the risk is not so obvious as that from the grey boar's tusks, and it was one that I could never bring 
myself to run for the flat and shapely legs of my beloved Arabs.

The essence of sport is to pit one's self against those powers of defence with which nature has endeavoured to protect the particular animal which we are endeavouring to lay low. Thus, when we approach the monarchs of the jungle, pachydermatous or carnivorous as the case may be, within a few yards, with only our trusty rifle in our hands, -and grand sport that is too, I warrant you,-we pit ourselves against their strength and natural weapons, just as when we slip our greyhounds at the flying hare, we pit ourselves against her speed.

Now, at one period of my life I should have had no hesitation in giving the sporting palm to fox-hunting, and even now I have great hesitation in dispossessing it from its 


\section{38 THE FINEST SPORT}

pride of place, and if I do so it is, perhaps, really only because I have not tasted its delights for three whole seasons. I will, however, make it this amends, that I undoubtingly place it at the head of English sport.

Before proceeding to examine it by the canons I have already laid down I will add one to their number, and that is that a certain risk of life or limb is necessary to give flavour to sport; and that a certain risk, although if we are guided by averages it is an infinitesimal one, we have in fox-hunting. ${ }^{1}$ But does it fulfil the others? In its original

1 Assuming that there are 160 packs of foxhounds in England, that an average "field" with each pack is 40, and that the average number of hunting days is 50 (all low enough surely), we get 320,000 people fox-hunting during the season. What is the proportion of fatal fox-hunting accidents, and that of other accidents to this undeniable underestimate? 


\section{THE FINEST SPORT}

form, the peep-of-day meet, the drag up to the find, and the long slow pursuit, it did perhaps do so, but nowadays we are rather inclined to sacrifice everything to " a gallop." No doubt a good fast run is the acme of foxhunting; but at the moment at which hounds are really brought to their noses, and the cream of the thing for the houndman is about to begin, how often nowadays are his delights marred by a "halloa!" Of course, there are many occasions when this is right and proper, such as when the pack is not quite a first-rate one or in proper condition ; or again, when a long-continued series of bad scenting days has made the obtaining of blood desirable, although I am much inclined to doubt if the best hounds are not those which don't require blooding at all.

But apart from the bad effect on hounds 


\section{40 THE FINEST SPORT}

of so often getting their heads up, I doubt very much if this hunting a fox by the assistance of halloas can be considered sport at all. The presence of the halloaer is an adventitious circumstance, on which the huntsman has no right to reckon. What should we think of a master who planned an elaborate system of vedettes, so that his indifferent-nosed towlers should be sure of assistance when they required it? Yet this would be only carrying the system of going to halloas to its legitimate conclusion. Which of us has not seen some pack or other where all day long the huntsman is assailed by such cries as "There's a halloa on, Jones," "There's a halloa back, Jones," "There's a man halloaing by Thicket Spinny, Jones," or "There's a chap wavinghis hat on Tump Hill, Jones." When we do 



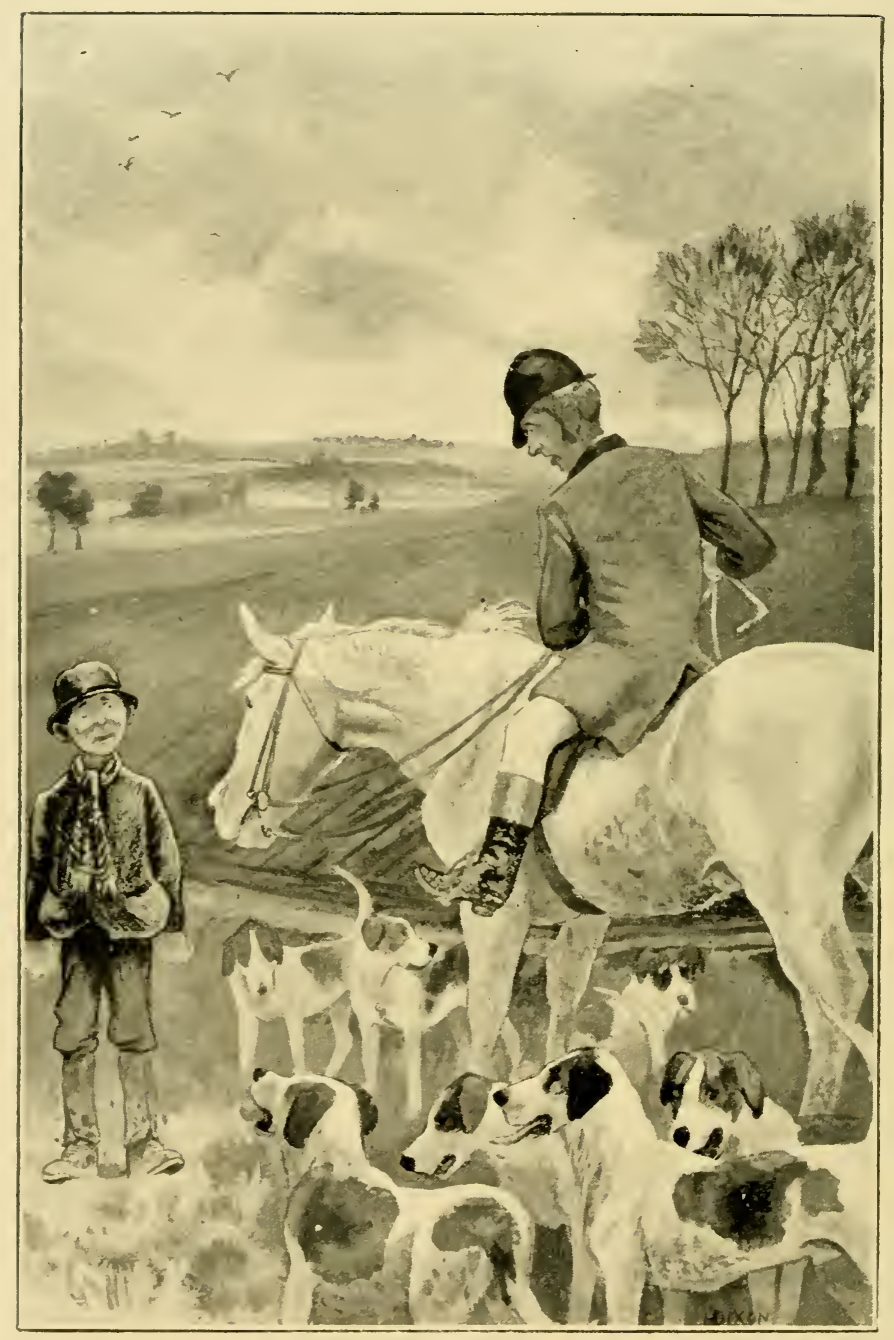

"WHAT THE DEVIL DID YOU 'ALLOA FOR?"

"COS I'SE PAID TO." 


\section{THE FINEST SPORT}

hear this sort of thing we need not pity Jones, the huntsman, for we may be sure it is his usual practice to out horn and gallop off to the distant bawler, regardless of what his hounds may be doing at the moment. The climax is reached when the following dialogue ensues.

Huntsman: "Where did you see 'im, boy?"

Boy (after a long stare) : "Zee wha-a-at ?"

H. : "The fox, of course."

B. (after thinking it out carefully): "Ain't seen narrun."

H. : "Then what the devil did you 'alloa for?"

B.: "Cos I'se paid to. I'se flaying rewks."

\section{(Tableau.)}

The real huntsman, who merely acknow- 


\section{2

ledges such information with a quick "Thankye, sir," ${ }^{1}$ will soon find that he gets less and less of it ; in. fact, if anybody offers it, it will be some old sportsman who knows as well as himself that if the run is to end with blood, they must be lifted now.

Of course there is the other extreme; the pack which no noise affects in any way, and very exasperating they can be on occasion also. But these are very rare, being in fact limited to a few out-of-the-way Welsh packs, of one of which the story has been told that after a kill they would cast themselves round, hit off the heelway, and run the line back again to the covert they originally found in.

Still, no doubt, fox-hunting is facile princeps of English sports. But there is

${ }^{3}$ Pytchley men will know who was in my mind when I penned this. Poor Goodall : 


\section{THE FINEST SPORT}

another sport which I am inclined to think very nearly equals it in every respect, save only that we neither have the music of the hounds nor the delightful feeling of having a well-bred horse under us-I allude to chamois stalking. But for me it must not be such chamois shooting as a good many Englishmen are familiar with, as, indeed, a well-known firm of tourist agrents were advertising the other day-I mean that in which the Herr is put under charge of a forester, who takes his rifle and leads the way for some hours, till at last, after peering over a ridge, he beckons his panting, perspiring "Master," and says, "The third from the snow-patch is the buck; shoot quick, or they'll be off."

No; if I am to have a companion, let it be a four-legged one-a dog who will lie 
down for hours where I tell him. Even he will probably be a hindrance to me during the day. Let the first glow of sunrise find me lying with ready telescope, on some rocky grat, in some recess of which I have passed the night as best I may, rolled in a blanket which the keeper brought up yesterday, and which he will take away to-day, together with the etna which made the cocoa, which has just warmed my stiffened limbs.

There they are! One, two, six, eight of them. I needn't watch these, for it is too early in the year for a good buck to be with a herd. Presently the glass falls on a second herd, then on two darker coloured beasts,_bucks, no doubt,_-but we will wait

${ }^{1}$ It is only fair to Mr. Carl Zeiss to say, that since I became acquainted with his prismatic glasses I have almost abandoned my telescope for them. 


\section{THE FINEST SPORT}

a little, although keeping an eye on them. Ten minutes later I catch sight of another, and this time a short inspection satisfies me that he would rank as a Bartgäms (an old buck chamois, the hair on whose withers is sufficiently long to make the much coveted trophy for hats) two months hence. I watch him carefully till at last he lies down. His position is carefully chosen, for his back is to a ridge of rocks hundreds of feet high, and sheer; and his eyes command the rock and snow slopes before him. But there is a blot on his plan of defence. To his right rear the high rocks are broken down in one place, and below this there is a gulf, the couloir at one side of which is just accessible. Once I am up that, I am above and within a hundred yards of my artful friend. Is it necessary to explain that on such ground the 10 


\section{I46 THE FINEST SPORT}

direction of the wind in the forenoon is usually, if not invariably, upwards? All depends on his not moving, for if he goes even a little higher he will see and hear me climbing up.

The next step is to climb down the grat I am perched on, and then I strike a long valley, mostly snow-covered. Two hours' walk and climb, mostly over snow and shaly slopes, brings me to the bottom of my couloir. Then I take the climbing-irons out of my ruck-sack, buckle them on, and commence the ascent. It has to be done carefully; and the best part of a third hour has passed before I crawl out on a flat rock at the top, pushing my rifle before me. My alpen-stock, ruck-sack, and climbing-irons I left ten yards back, together with my nailed shoes. 


\section{THE FINEST SPORT}

The first careful reconnaissance produces no result; but just as I am beginning to fear my solitary friend has shifted his position, I see a movement which proves to be that of his head, everything else being hidden by the rocks. As I have no intention of lying here till he rises, which will probably not be till the sun is sinking, I reach out for a loose piece of rock and place it cautiously near my right foot. Then I get myself into position, and push it over the edge of my rock. Down it clatters.

"Whew!" As I calculated, the buck springs to his feet with a whistle of alarm, and then stands like a statue, his head turned in my direction. He probably cannot distinguish my recumbent and motionless figure, but this is not a question that I await for time to decide. The bead covers the 


\section{I48 THE FINEST SPORT}

fatal spot where the lines of the fore-leg and belly meet; and I press the trigger. What a bound! But his legs fail him as he alights, and he rolls over and over down a snowslope. Nu fear of his rising again.

As soon as I have recovered my shoes and other impedimenta I follow him, and put the tape on his horns. Ten inches and an eighth! Well worth the trouble they cost to get. I should not care to eat him, but the foresters do, so I gralloch him, and mark the spot as best I can for the man whom I shall send for him this evening.

This is the baldest description of a stalk, and one, too, of the simplest and safest kind. I have not dwelt on the natural beauties of the ground we encounter in this sport, although it is not too much to say that if from our hill-top we fail to find our game, 


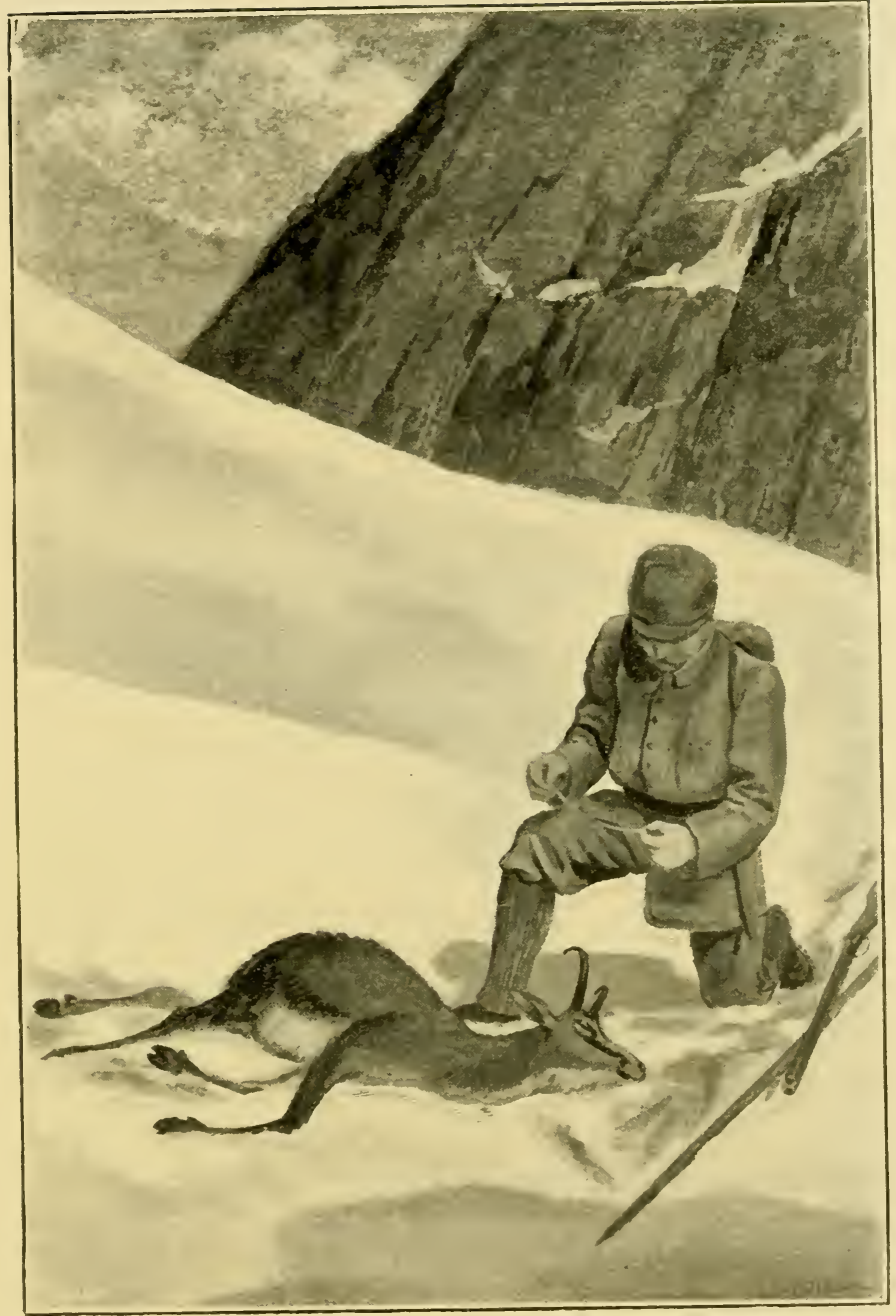

PUT THE TAPE ON HIS HORNS. 



\section{THE FINEST SPORT}

the view alone will repay us for our climb. Then there are the hairbreadth escapes from dangers caused in a hundred ways, but, above all, by fog; the disappointments, and even the misses which give variety to the sport. One last thing, the author of Short Stalks says he never recollects having a totally blank day's chamois shooting, i.e. without his seeing game, and my limited experience confirms his extensive one. We both shot, be it remembered, on unpreserved ground. 


\section{XIII}

\section{ROUND THE BOUNDARIES}

GOOD many owners and tenants of 1 shootings are, it must be confessed, bond slaves to their gamekeepers. But even amongst those of us that are not, there must exist some natural sympathy for the feelings of "Velveteens." I take it that there is no way more calculated to outrage these than by disturbing the coverts between the end, say, of October and the first "shoot" of the season. Keepers are not, though they are so often depicted, men whose only idea is 


\section{ROUND THE BOUNDARIES I5I}

the "tip" which they look to receiving after a successful day's sport. Generally speaking; they take a proper and honest pride in showing a good head of game, furred and feathered, to their master and his guests.

What can be more disheartening to a man who feels like this, than to be obliged to run spaniels through his coverts and disturb some scores of pheasants, for one or two guns who cannot possibly get shots at one-half of them, and who very likely don't bag one-fifth? $\mathrm{No}$; the coverts par cxcellence should be a sanctuary until that winter morning, when, with his guns scientifically posted, and his stops at their places, the keeper enters them with his smock-frocked myrmidons, to send the feathered citizens exactly where they ought to go.

But we can't be always hunting (don't 


\section{I52 ROUND THE BOUNDARIES}

hunt, indeed, some of us), or golfing, or even smoking. Some days there are when we feel we must "go and kill something."

Then we wander out to the gun-room after breakfast, and tell the keeper we will "just take a turn round the boundaries." Whereby we get him on the soft place. The boundaries, especially in a small shooting, are ever a sore point with him. He has a deadly hatred (veiled in a thoroughly Christian but somewhat patronising manner) and contempt for the keeper adjoining. He even suspects him of that exceedingly unsportsmanlike device, putting down a "cage" in a boundary woodland. He knows him to be guilty of raisins, and he even resents the (quite legal) appearance of the other's spaniels on his side of the boundary fence. He believes the other 


\section{ROUND THE BOUNDARIES 153}

keeper incites yokels to purloin his pheasants' eggs, and even his ant-hills. He openly accuses him to his own master of vulpicide, thereby it may be veiling his own delinquencies. Apart from this, he knows, of course, that the game on the boundaries is no man's game. He cannot be sure of leading those plaguy old cock pheasants, which are foolish enough to prefer hips and haws and grubs to his corn, back home; therefore master had better have them than anybody else. So without a grumble he goes to the rack and takes down a gun.

"No; the twenty," says the master; and down comes the little favourite-than which there can be no better weapon when there is much walking to not very much shooting. Then the keeper fills a cartridge-bag, which he balances with a game-bag on the other 
I54 ROUND THE BOUNDARIES

shoulder, takes his stick, and is ready.

$\mathrm{His}$ three-score years sit lightly enough upon him, for he is, indeed, a man with "life experience"; and, truth to tell, he can walk down some younger men in a long day in a rough country. Meanwhile the master has gone for his hat, and they meet at a side door of the house. The master is accompanied by a couple of favourite dachshunds. The keeper used to turn up his nose at these at first, but now he admits them to be useful though "desperate hard-mouthed." A quarter of an hour sees them clear of the lodge gates, and down a hill through some cottages; but, though they are past the boundary, they trudge on, and turn off up a right of way through some fields on an adjoining property. But this path touches the extreme corner of the shooting, and it is 


\section{ROUND THE BOUNDARIES I55}

with the object of circumventing an outlying covey, which frequents that corner, that this roundabout route has been taken. Once over the wall, the master takes the gun and a handful of cartridges, and loads. Then a quiet advance is made; the dogs, though eager, obedient to the signalling hand. Not half-way up the field, in which the brown bracken grows freely, whirr! up gets the covey. A brace fall; and at the double report a hen pheasant rises fifty yards on and tops the boundary fence. But our sportsmen are following the covey with their eyes, till it drops in a high gorse cover above. That gorse is full of pheasants, as both know, so the partridges are left in peace; the fallen birds are gathered, and on they go. The field holds nothing more but an outlying rabbit, which is not wanted. 
I56 ROUND THE BOUNDARIES

Meanwhile the sportsmen have crossed the fence into an open oak grove. By jumping the ditch they disturb something. Flap! flap!--Down! The first cock of the season. One must look at it. It is still alive. The beautiful eye is fortunately quite inexpressive; there is nothing to show agony, though pain there must be. The head droops; it is over. The ground runs to a point here, and at the very end up gets a cock pheasant; and gets away safely, too. Well, one must miss sometimes. But that was a bad one. The rest of the northern boundary is blank, save of rabbits, which are not shot at.

Before going on, our pair turn back through some fields, to where a little covert lies between an orchard and a meadow. It is not near the boundary, but it has been 


\section{ROUND THE BOUNDARIES 157}

planted for days like this, and runs out at right angles to the big wood. Master stands out in the meadow, and keeper, rattling his stick on the fence, runs the dogs through the covert. A brace of young pheasants rise simultaneously, and flop! flop! they fall on the grass. Truth to tell, it was rather an easy double shot.

From here their way runs up a disused hollow lane, but though the dogs find several birds, they run into their own or the neighbour's coverts and give no chances. At the top is a mere strip of woodland against a large wood- "Another's," as the despairing lover says in melodrama. Master gets on to the end, and keeper and dogs work it through. Up get two cock birds. One goes down, and the other is not shot at. Keeper gathers the bird, with a broad 


\section{${ }_{15} 8$ ROUND THE BOUNDARIES}

grin, which becomes broader than ever when at the next turn they meet the other keeper peering out to see "who's arter his birds." The politeness of his "Goodmorning" is most crushing. A couple more birds are seen as they coast the southern boundary; but nothing is done till they reach the edge of a bit of low cut cover. Through this the dogs are run. A dozen pheasants rise and go on unfired at ; but one, who is audacious enough to rise high and try to sail back towards a wood over the march, is collapsed with a broken wing. Marked down he is, of course, missing, but the dogs draw up the line. Keeper follows, and two hundred yards up the cover he finds the dead bird.

"I feel I could do some lunch," says master, and off they go homewards. 


\section{ROUND THE BOUNDARIES 159}

An hour or so later they start again. The shooting this time is in the opposite direction. Master presently disappears towards a railway visible below. A little covert lies between a turnpike road and a deep cutting. Keeper and dogs enter this with the result of sending a brace "very high" over master standing on the line. One falls with a crash on the very bank of the river which adjoins the line, and as the sportsman goes to get him, a hen rises from some brambles, and starts off to cross, too, but death meets her in the air. Into the water she goes splash. Fortunately, a boat is moored just below, and before the keeper can get down the hill both birds are laid together, and his master is looking for a possible duck in a bushy backwater. Duck there is none; but keeper kicks out a hare 
160 ROUND THE BOUNDARIES

in the rushy field, and off go the dogs in pursuit. As master scrambles up the bank he meets puss almost face to face, turning her sideways, when she gives a safe shot and rolls over.

Then for a long time nothing is done, conscientiously, as a series of gorsy grass fields, bordering a huge wood, are worked out. They hold nothing but rabbits. The sportsmen pass between two well-stocked coverts (of the keeper's own) and strike the high road. Here the shooting is only a strip of grass, but the dogs feather and scramble through the hedge. Forty yards on they put up a cock pheasant, who, rising and gathering height and way, comes best speed for his sanctuary - the covert. A sporting shot, and well killed, as the thump on the ground attests. 


\section{ROUND THE BOUNDARIES I6I}

"Try the long hedge, sir?" asks the keeper.

Receiving affirmative answer, they go, one on each side, down a thick fence all the way to the river. A little brook skirts it, now one side and then the other. Two pheasants are added to the bag, and at the very bottom, where the meadow is marshy. scape! scape! up gets a snipe, and is neatly grassed.

Then they go home through the gathering gloom. 


\section{XIV \\ COACHING IN CEYLON}

Ye gentlemen of England, who sit at home at ease, How little do ye think upon the perils of the seas -

wrote one of the gallants of Charles the Second's court when tumbling about in Monk's squadron off the Doggerbank. I might paraphrase him, and say, how little the British coaching man, comfortably ensconced on box or brake-seat of the "Old Times" or "Comet," thinks upon the miseries which the so-called coaches in many of our colonies inflict upon their unwilling 


\section{COACHING IN CEYLON}

163

passengers. From time to time one sees accounts in the papers of coaches and coaching in America or Australasia, but I do not think that I have ever seen Ceylon coaches referred to. As, from a long and regrettable acquaintance with these vehicles, I have acquired some right to speak of them, I propose to try and give the reader some idea of the way in which coaching is carried out in the land of spicy breezes.

At the time I write of there were in Ceylon six regular lines of coach traffic. Firstly, came the Galle and Kalutara coach, which for many years was the most important of all, connecting, as it did, the mail port with the railway to the capital. Since the new breakwater has enabled the great steamship companies to call direct at the 


\section{I64 COACHING IN CEYLON}

capital, it has lost all its importance, and very likely has ceased to exist. In connection with this coach there was a short line from Galle to Matara, a journey of about two dozen miles. From the capital, Colombo, there was one coach only, which ran to Ratnapura, and had an unenviable reputation for accidents. Much of this road was under water after heavy rain. From Gampolla Station a coach ran up the tremendous Ramboda Pass to Newera Elliya, the sanatorium, which is seven thousand feet above the sea. The iron horse has now run this off the road; and the same remark applies to the Kandy and Matale coach, which ceased to exist in I880. Finally, there was a coach from Polgawhela Station to Kurnegalla, the capital of the North-Western Province. All I know about this coach is that a friend of mine 
travelled by it and was upset twice, down two separate embankments, in one morning.

The main roads in Ceylon are probably unequalled in any country in the world, and are, I believe, kept up by forced labourthat is to say, every able-bodied male inhabitant has either to do so many days' work on the roads, or to pay a substitute. Near the sea-coast the roads are repaired with cabook, a disintegrated coral, and are practically all dead level. The inland roads ascend terrific hills, but the gradients are as scientifically arranged as possible. The old Kandy and Colombo road, which has long ceased to be a coach road, even goes through a tunnel. Anent this I may be allowed an anecdote. There was an old prophecy about a certain hill near Kandy, 


\section{I66 COACHING IN CEYLON}

that "when a bullock cart was driven through the hill, the Kandyan kingdom would come to an end." After the final capture of Kandy by the British, the road was made and the hill in question tumnelled, thus singularly fulfilling the prophecy to the letter.

The Ceylon coaches are of uniform pattern, and very unlike our idea of a coach. The main body consists of a very broad "coach-inside" to accommodate three on each seat. In front is a low driving-seat, which affords room for one passenger, or sometimes two. Behind, facing to the rear, is another seat, which is very uncomfortable, and always occupied by natives. On the footboard of this the guard squats. The roof is merely supported on iron stanchions. Curtains of American cloth hang from this, 


\section{COACHING IN CEYLON 167}

and they can be lowered to exclude the sun, or raised to admit fresh air.

Now I come to the horses, and here I am fairly nonplussed as to what to say. Perhaps I can best give an idea of them by saying that the price paid for them, in a country where good horses cost more than in England, was, as a rule, fifty rupeesthen worth is. 8d. each. Seventy rupees (under $£ 6$ ) was quite a top price. As very small horses, or cripples, were no use, it followed that a great percentage of the horses used were incurably vicious. Two horses only were harnessed to the coaches, which were heavy enough when loaded with a dozen people, and luggage on top as well as some swinging underneath. The horses were invariably stallions, except in the rare cases when a "Waler" was 
condemned to the coach for incurable buckjumping.

Perhaps I can best give an idea of the way the Ceylon coaches are worked by describing a drive I once had from Kalutara to Galle. It was neither my first nor my last, but has, nevertheless, remained in my memory. When we arrived in the train from Colombo we found the Galle coach waiting at Kalutara Station. Amongst the inside passengers were a couple of English ladies. I had the box seat to myself. At this time I was new to Ceylon coaching, and examined all I saw with curiosity. The horses, two grey Indian country-breds, each held by a native, were simply harnessed with collar and traces only, like London 'bus horses. No doubt to protect us from kicks, the leather dashboard was supplemented 
with a stout wooden one, and the space between the two was filled with rolls of stout coir rope as thick as one's finger. The use of this I was yet to learn.

At last the luggage and passengers were "all aboard." The driver, a native of course, dressed in dark-blue serge, gathered up his reins, while the guard, who was similarly dressed, except that in his case knickerbockers and bare legs took the place of trousers and boots, blew the bugle strung from his shoulders, and we were off. The starting teams are always the best; but on this occasion we had not gone far when the horses caught sight of each other. Forthwith they neglected their business of pulling the coach, and began a regular fight. The guard rushed to the rescue, and they were induced to give up their amusement. Mean- 


\section{COACHING IN CEYLON}

while the driver, a man of resource, handed me the reins, and, taking one of the rolls of coir rope, got down. In a couple of minutes he had extemporised two stout side reins. These prevented the brutes from seeing or biting each other, and they finished the stage well enough. The stages were short ones; about seven miles is the average.

After the greys had been taken out, the near horse was harnessed, but there seemed to be some delay about the other. At last he appeared. Directly he saw the coach he stopped, and nothing, as far as I could see, would induce him to move. I was not then acquainted with the resources of Ceylon horse-keepers. First a twitch went on his nose, then one on each ear. A rope was even passed round his fetlock. These inducements, together with a volley of kicks 
and blows, brought him at last to his place, and he was harnessed. Then he refused to start. After various modes of persuasion had been attempted in vain, a local genius (there are always half a dozen natives assisting on these occasions) slipped a piece of coir rope under his fore-arm. This rope is very rough, and he sawed it backwards and forwards. Flesh and blood could not stand this; the brute plunged into his collar. The near horse had been pulling for some time. The horn sounded, and that stage was soon left behind.

The next change introduced us to another variation. The near horse was harnessed as before. They generally pair them so-one quiet horse, one brute. The other was got to the pole-head, but obstinately declined to approach nearer. There he stood, facing us. 


\section{I72 COACHING IN CEYLON}

The pole-chain was connected, also his inside trace, while the guard held the outer one. Then the driver whipped up the near horse, three or four natives manned the wheels, and the coach started. We "overtook" the off horse; he swung round into his place, and was galloping by the other long before the guard had secured his off trace and regained his own seat.

Whilst our coach is rapidly rolling over the next stage or two, let us take a glance at a Ceylon low-country road and its surroundings. For the most part these roads are, as I have said, dead level, and rarely out of sight of the white breakers tumbling incessantly on the coral reefs which fringe the coast. For nearly the whole distance, too, they run under overhanging cocoa-nut palms, the great leaves of which clash and 
hiss as the damp, warm wind sways them. Frequently we pass native huts built of mudlike conglomerate, and roofed with thatch made of palm leaves. These are generally surrounded with the bright green foliage of the plantain or banana. The natives one sees at work are either engaged in fishing with long seine nets or employed in some of the hundreds of forms in which the cocoa-nut is useful to man. Here and there a bullock is slowly revolving round a stone-crushing mill, in which the kernels are being crushed to yield their oil. Again a dozen natives are splashing about in the filthy tanks, where the husks are being rotted to facilitate the removal of the fibre, or women are collecting it, drying it, or making it into matting or rope. Lastly, here and there natives can be seen in the tree-tops, plucking the nuts, or 


\section{I74 COACHING IN CEYLON}

removing the pots of intoxicating "toddy," which have filled during the night.

Of tropical animal life we see little, unless it be a troop of monkeys among the trees. When we pass the open rice fields, or thick pieces of jungle, barbets, golden orioles, kingfishers, and other bright-coloured birds are to be seen. Again, at times huge iguanas, as big as small alligators, shuffle off the road, hissing angrily.

A stage or two further on we made the acquaintance of a typical Ceylon coach horse. There appeared, squealing at the sight of the coach, about the most repulsive-looking specimen of the equine race $I$ have ever set eyes on. In colour it was a pale dun, with white main and tail, its nose and underparts pinkish, and the eyes distinctly green. I will pass over struggles lasting nearly half 
an hour, and suppose it harnessed. The wheels were manned, the other horse pulling; but the dun hung back so from his collar that his hind-quarters began to slip under his outer trace. I stopped this by standing on the trace, and then he tried the other side, and actually got partly under the pole. The jabber of the natives, the shrieks of the ladies, and the curses of the driver can be imagined. At last the latter ordered the horse to be removed and sent back to Kalutara. Another horse, probably one of those which had just done a stage, was fetched, and we were at last under way.

Always being anxious to learn, and thinking they probably had some local means of "Rarefying" such brutes at the terminus, I asked the driver what would be done with the dun on his arrival 


\section{I76 COACHING IN CEYLON}

there. "Now good shoot," was the laconic reply.

The rest of our journey was marked by no greater excitement than a pair of horses which reared and then dashed so violently into their collars as to smash the traces. Although this happened twice during the stage, we still had plenty of coir rope left, but at the end of our journey we had used the entire supply.

At last we rolled round the green esplanade and through the old Dutch gate, and pulled up at the Oriental Hotel, then in the zenith of its prosperity.

I am afraid the vice displayed by Ceylon coach horses is not at all due to "original sin." Natives are horribly cruel to animals. I do not say it is the case in the mail coaches, but in some of the others it is simply 
physical pain which causes them to jib. On one occasion I missed the mail, and travelled from Matara to Galle in a so-called "coolie coach," a long waggonette full of natives, and drawn by two wretched cobs. I got down at a halting place and was horrified to see the off horse was raze from shoulder to shoulder. A dozen miles from anywhere, I could do nothing. I fear that, even in the mail coaches, sore shoulders are the rule rather than the exception.

It was on one of these "coolie coaches" I saw the most amusing change of horses I ever heard of. E--, who at that time was "Grain Commissioner" for the island, heard I was going from Galle to Colombo on a certain day, and kindly offered me a seat in his dog-cart, to save me the coach drive. He had his own horses stationed at intervals 


\section{I78 COACHING IN CEYLON}

on the road. I gladly accepted. His plan was to sleep at Bentota-as famous in Ceylon for its oysters as Whitstable is in England-and drive the same horse on in the morning to Kalutara railway station. As far as Bentota all went well; but, unfortunately, during the night there our steed was badly griped, and quite unfit to proceed next day. We were, however, able to fall back on a " coolie coach," a waggonette full of natives, of which we had the box seat. As the ponies were very small, I could not help asking the driver when we had got halfway to Kalutara if he were not going to change horses. He replied that he was, about a mile further on.

Accordingly, in about twenty minutes' time the coach stopped. I saw no fresh horses nor stabling, not even a native hut 


\section{COACHING IN CEYLON}

by the roadside. However, the driver and guard got down and unharnessed their nags. At the end of two or three minutes the unfortunate animals were again brought up to the vehicle and "inspanned," the only change being that the previous off horse was now the near one, and vice versâ. Before E- and I had finished laughing at this most original change we were off again, and duly caught our train at Kalutara.

Coaching accidents are almost unknown in Ceylon, except perhaps on the Ratnapura and Kurnegalla coaches. The low-country mails owe their immunity from accident to the fact that, as before said, the roads run through dead-level country - on a level, moreover, with the road, which is not ditched. So if the coach does leave the 


\section{COACHING IN CEYLON}

road no harm is done. Up-country coaches are better horsed and driven. I recollect a curious accident happening to one of these. The place selected for change of horses was on a slight hill. One day the old team had been taken out, and all the passengers had got down. The horse-keepers, however, had entirely neglected to scotch the wheels in any way. Presently the abandoned coach started slowly backwards, and before anyone could intervene, its rapidly increasing momentum carried it over the edge on the other side of the road, down into the coffee plantation fifty feet below. There I saw it some time after, and I daresay it lies there still, for the work of extrication promised great difficulties.

It will be seen from what I have already said that "coaching," as we understand the 


\section{COACHING IN CEYLON I8I}

term - that is, driving four horses - is unknown in Ceylon. Tandem-meets, on the principle of "you've got a horse and I've got a horse, and Smith's got a pair of long traces," were common enough in my day, and I daresay they are still, though I doubt if anybody has since then driven a tandem of ponies ten hands and a half, as I did one year.

There was once, however, a drag in Ceylon, and the story will perhaps bear repeating. Wild horses shall not drag from me the name of the owner of that coach. Suffice it to say he is my very good friend, and an influential member of the Badminton Club Committee. Well, he imported a drag from England, horsed it, and drove it. The drives, however, were of a secret nature, a mere rehearsal of what was to be the crown- 
ing glory-its appearance at the Colombo Race Meeting.

The first day of the races came. Expectation was on tiptoe. The drag arrived. The proud owner, with elbows squared, and whip scientifically caught, pulled up and deposited his load of "fair women and brave men" at the entrance to the stand. In fact, the drag was quite the feature of the meeting, and all agreed that Sandown or Ascot could not have seen the thing better done.

On the second day the coach created less attention, although everything went as well as ever. Scarcely, however, had the horses been removed when the notes of a second "yard of tin" drew everybody's eyes towards the road once more. This is what they saw.

A "palanquin carriage" (the ordinary cab 


\section{COACHING IN CEYLON I $8_{3}$}

of the place, resembling a demoralised growler, with venetians instead of glass) had been aptly fitted with an extemporised dickey and coach-seat facing it. Between these was an enormous lunch hamper. On top of this "coach" were a wild crew of the most notorious practical jokers of the community. In smartness of get-up, frock-coats, white hats, and blue veils; they were in no way inferior to the load on the drag which had preceded them. The imitation article was, however, "horsed" with a team of the big grey bullocks which come from Southern India ; and these, stimulated by the whacks and shouts of their drivers who ran beside them, rapidly approached the stand amidst the yells of the natives and the roars of laughter of the European population of Colombo, Lest the laughter should not 


\section{84 COACHING IN CEYLON}

have been sufficiently Homeric, the whole incident was cleverly sketched by a young civil servant, and the sketch being photographed brought the laugh home to every bungalow in the island.

But we were to have another laugh over that drag yet. Not very long afterwards the owner decided to send it home. But, mindful of the fact that freight is charged by bulk, he decided to economise part of the expense by packing it full of other luggage. Unfortunately, this is probably the one strain no coach-builder has ever contemplated. The result was that, as it was being swung from lighter to steamer, the bottom of the drag fell out!

Here it is surely best to draw a veil. 


\section{XV}

\section{POOR PUSSY!}

THERE are few more painful spectacles than the British public in one of its periodical fits of wrong-headedness. It must be admitted that it was during one of these that the Ground Game Act was placed on the Statute Book.

When we consider this Act, not for the moment by the light of its working, but calmly and dispassionately by its contents alone, nothing, I think, strikes us so forcibly as its utter tyranny. As a rule, a landowner 
knows what he is about, and certainly a farmer does. But the law, forsooth, steps in and says to those two men, "You are neither more nor less than children, and incapable of managing your own affairs. You (to the landowner) are such an ass that you keep up such an absurd head of game that no farmer will take, or stay on, your farms; and you (to the farmer) are such a fool that you will actually rent, or remain on a farm on which the stork of ground game is so excessive as to eat up all your profits. Therefore it is necessary for me to step in and put matters right." Will anybody maintain that if a circular to this effect had been sent to all the landowners and farmers in England they would not have resented it? Now we can only resent the effects of the Act, and this we 
do-nearly all the landlords and the best class of farmers too.

'The fact is ( $\mathrm{I}$ am really ashamed to put so obvious a set of facts before sensible readers) this was exactly one of the things which correct themselves. The only estate where it was ever brought to my knowledge that an excessive head of game was kept up was one in Shropshire, belonging-I write under correction on this point-to the late Lord Forrester. I speak of the early seventies. Well, what was the resilt? The result was that, as my informant put it, "they can't keep a tenant." An uncle of mine had an estate in Galloway. "Look at this cornfield," he said to me one day. It was indeed a sorry sight. "I believe the infernal fellow does it on purpose," he continued. "You notice it is surrounded by coverts on three 
sides. The result is that I have to pay him for a top number of bushels per acre, and straw; and he saves the costs of harvesting:" It was on this estate that a deputation of tenant farmers once appeared in the laird's room. "What is it?" he asked. "Weel, laird, it's just this. Yon rabbit-catchers fra' Leeverpool pay you twa houndred pounds the year for the right to kill and take the rabbits. Now, as it's we that feed the rabbits, we jalouse that it's we that ought to have the benefit." "Oh, is that it?" quoth my uncle; "there certainly seems reason in what you say. The rabbit-catcher's agreement is, as you may have heard, a yearly one; and so I shall not renew it. After this year the rabbits are yours." Exit deputation wreathed in smiles. 
Not two years had elapsed when pretty much the same party appeared once more in my uncle's study.

"What can I do for you now?" he asked. "Weel, laird," was the spokesman's answer, "it's this way. We're just fair eaten up wi' the rabbits." "The rabbits? But you've got the remedy in your own hands. Why don't you kill them down?" "We canna. What wi' one that hasna time, and another that doesna ken how, they're eating us up." "Well, what can I do? I've been sparing them, thinking you wanted them; but I'll have a shoot or two, if you like." "It isna that, but-but, laird, if ye wad be so guid as to send for those men to Leeverpool, and just tak' them into your own hands again."

This was ultimately done. I need hardly 
say this was years before the passing of the Ground Game Act.

But so far I have spoken principally of rabbits; and bunny can look after himself. Except in a few odd places, he is neither exterminated, nor likely to be. I plead for the hare, which is fast disappearing in many places. The recent Act forbidding the sale in summer months may do something, but I have only heard it spoken of, as a rule, as "the thin end of the wedge." This is a mistake. We must not think we shall get half the Ground Game Act repealed. That question has unfortunately been made too much a party question. Nor, I think, shall we, without a lot of trouble and without causing much ill-feeling, get a proper close time for hares such as pheasants have. The spirit of to-day is towards decentralisation, 



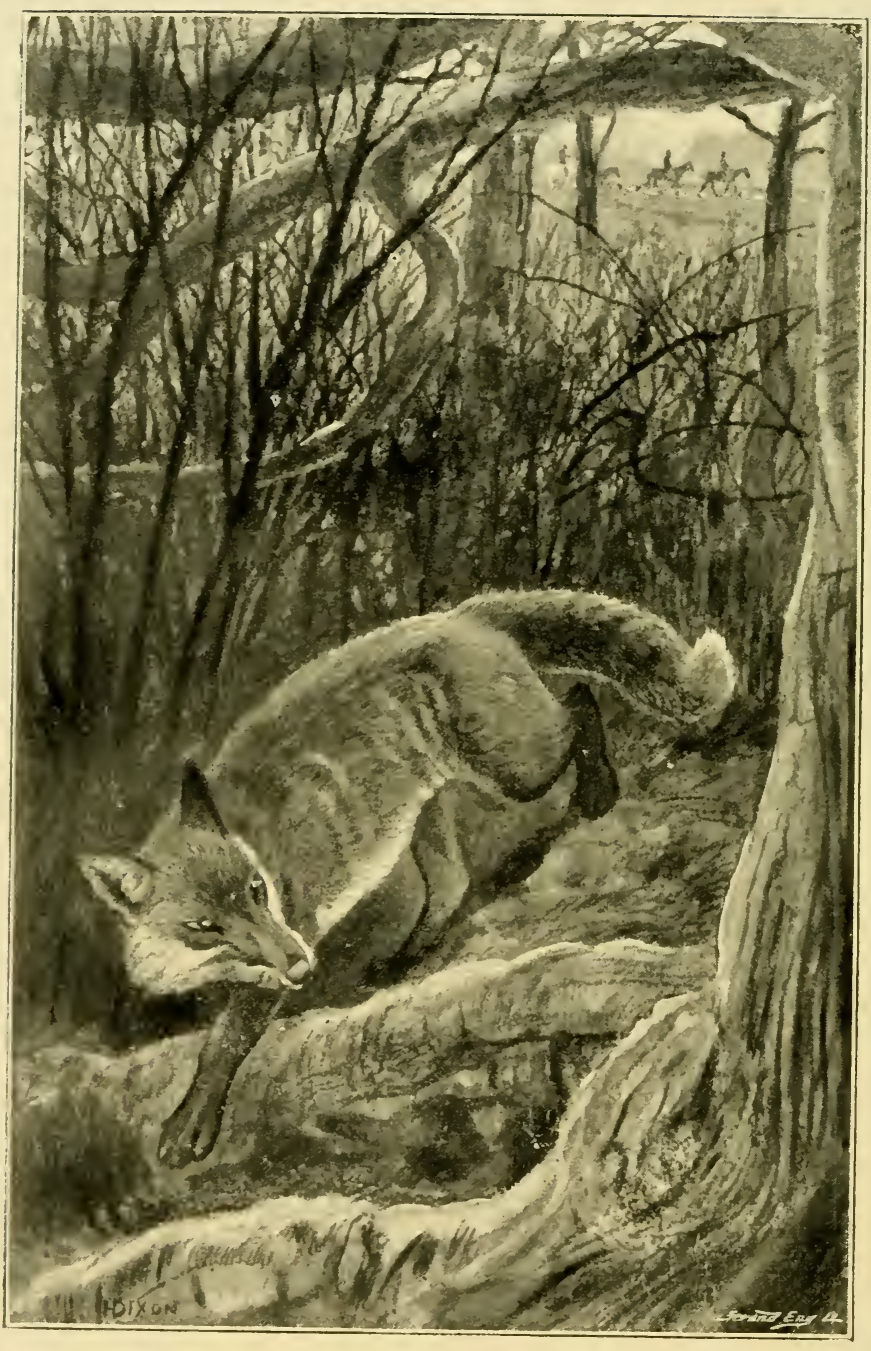

THE FOX IS SAFE ENOUCH. 


\section{POOR PUSSY!}

and the present working of the Wild Birds Act must serve as our model. I want sportsmen throughout England to consider the advisability of a Wild Animals Act-a permissive Act giving County Councils the power to legislate for a close time for any animal that is good for food. The fox is safe enough, and the otter is getting more protected daily. Nor do I think the badger is in any need of protection. Anyhow, it would be absurd to try for a law to protect noxious animals, though not so long ago, in an Austrian sporting paper, I saw an enthusiast clamouring for a close time for bears, which, by the way, make a very good one for themselves by disappearing into their gauras from October to April. County Councils, presumably, know their own business; and I have little doubt 


\section{2 POOR PUSSY!}

that most, if not all, of them would within a very few months fix a close time for hares-a thing I have so often urged-not because of the threatened extinction of the animal, not because a breeding hare is worthless for food, but from common humanity, to stop the too-frequent practice of to-day, of shooting the doe and leaving the helpless leveret to die of starvation.

Next in order among animals which would be affected by such a law come our native British deer-the red-deer and the roe-deer. Here it is desirable that the power of Councils should extend not only to species, but also to sex. With hares, of course, this is impossible; but in Germany and Austria the stag and roe-buck get (very properly) quite a different close time to that of the hind and the doe, which last, in nearly all 


\section{POOR PUSSY!}

English counties, would want a year long close time for the next half a dozen years, at least.

Lastly, the Act should empower Councils to protect useful animals, not actually British, such as the fallow-deer (which is so common now that it will almost surprise some to hear that it is not a native deer), and the Japanese deer (Cerous sika), also to be found in many parks nowadays. I have a great affection for this latter little animal. It is very handsome, and its antlers, if small, are at any rate a good deal more of a trophy than those of the roe-buck. Also, like that animal, it is essentially a woodland deer, and would never be likely to lead to an outcry among the farmers. As to the roe, I had better refer the interested to my chapter on " Roe-shooting," which appeared 


\section{I94 POOR PUSSY!}

in Gun, Rifle, and Hound. The red-deer, on the other hand, is a destructive brute, and will soon play "old gooseberry" with standing corn or potatoes. But the mere fact that it would be the County Council who would lengthen or shorten his days of grace is a sufficient guarantee to the farmer. 


\section{XVI}

\section{A DILIGENCE DRIVE IN AUSTRIAN TURKEY}

"A USTRIAN TURKEY" is, I venture of designating the two provinces officially known as "Bosnia-Herzegovina," since, as a matter of right, they belong to Turkey, and as a matter of fact to Austria; and it was in these provinces the drive I am about to describe took place. The point of departure was the pretty little Government hotel $\underset{195}{\text { at }}$ Jablanića, in the 


\section{A DILIGENCE DRIVE}

Herzegovina. At this point the gorge of the Lower Narenta is at its grandest, and the bare and towering mountains surround the beautiful gardens of the hotel on every side. No district in the Herzegovina contains so many chamois as this, which for years has been a sanctuary, but is now to be divided up into rented shootings. The week after I left there were two unsuccessful bear-drives in the Prenj district on the opposite bank of the river, from which came sad complaints of slaughtered beeves.

At eight o'clock, on a fine summer morning, I found my diligence drawn up at the hotel gates. I may say "my diligence," as I was the only passenger, and had my choice of four seats-rather straight-backed-in a roomy landau, or of two in a coupé, stuck up in front behind 


\section{IN AUSTRIAN TURKEY}

the driver's seat. This last was so low that it seemed inconceivable a team could be driven from it, and the length of the driver's whip made it appear incredible that he could possibly hit the leaders, which, like the wheelers, were somewhat leggy but well-bred-looking Croatians. The immensely high boots, shiny hats, and curly horns one naturally associates with a diligence were conspicuous by their absence, driver and guard being dressed in a simple uniform far more suggestive of a steamboat than a coach.

The stationmaster bowed, the gendarme saluted, I took off my hat in reply, and we were off. The pace at first was decidedly moderate, as numerous wooden bridges over affluent streams had to be crossed, and this must be done at a walk. 
IgS A DILIGENCE DRIVE

Our way ran up stream, generally between railroad and river, but we crossed the former once or twice. At last we reached the spot where the Rama enters the Narenta. This spot is memorable as the place where lived the last Bogumilesthat strange sect which opened the way to these provinces for the Turk. Here we parted company with the railway line.

The traveller who is not familiar with some of the less accessible beauties of these provinces, the Sujeska Valley, the Drina, or the Upper Narenta, may well doubt if they can show anything to surpass the Rama Valley, along which our road now lay. At the end of an hour or so we stopped at a wayside trough to water the cattle. This was done by first letting the leaders drink, and then taking 
them out while the wheelers took their turn. A bucket would have saved five minutes at least, but time is not of much value in these provinces. It must be said, however, that the diligences and post-carts show a rate of speed infinitely superior relatively to the disgraceful performances of the local railways. In fact, they go about half as fast as the latter. Presently we passed a new church of large size-not yet finished indeed; and picked up a passenger, whom two jolly friars had come to see off. He did not go far, though, for he left us about half an hour later at a han, where we stopped for ten minutes. The staff consumed beer; and I had one of the excellent pots of black coffee one gets everywhere in this country for a penny. Then we went on again, 


\section{0

and at last we left the Rama Valley, and entered upon an almost endless winding road, which led up to the ruined watchtower which gives its name to the village of Prozor (Look Out). As we were coming up it seemed the end of everything, but as we entered the village we caught sight of further heights above it.

At Prozor we stopped an hour, and I had an excellent lunch, with a bottle of sound wine, and coffee after, for a shilling -a pretty clear proof of being a long way off the ordinary tourists' track. Then I lit my pipe and walked out to find a fresh team waiting, and a fresh passenger in the shape of a young priest, who, however, preferred the coupé. We crossed a plain and began another series of serpentine 


\section{IN AUSTRIAN TURKEY 20 I}

windings which, for the first time, brought us from a trot to a walk. The whole hillside was scored with old roads, and one could plainly distinguish, first, the old native track; secondly, a rough Turkish paved track; then a steepish military road; and, lastly, the one we were on, visible for miles above and below us. At last we reached the pass-a signboard in it showing an elevation higher than any mountain in England - and plunged merrily down into a narrow and wooded glen, succeeded in its turn by a fertile plain all the way to our journey's end. In a largish village we rested and drank coffee. The old woman who kept the han spotted my nationality at once, and asked me if I were not the son of General B. I regretted I was not, but was able to tell 
her that General B. (who is unmarried, by the way) was at that moment in the Pyrenees. Although I never met the gentleman in question, he seems, like myself, to have a fancy for travelling off the beaten tracks; and I seldom go anywhere without being asked, "Do you know General B.?" We now followed the Vrbas stream (which I was destined to see again, almost a river, and receiving the magnificent Falls of the Pliva), and it finally led us to Bugoijno. Our eight hours' drive was over.

Next morning at five o'clock I heard the horn. Yes, a yard of tin this time, but curled round and round, and slung round the neck of a guard. My conveyance this time was officially styled a postwagen, not a diligence, and therefore 


\section{IN AUSTRIAN TURKEY 203}

we were only treated to a pair of horses. The conveyance consisted of a sort of char-à-banc. On the first of its seats sat the driver and guard, the second was available for passengers, and on the third (back to back with the latter) was seated the escort, an infantryman armed with rifle and bayonet. Considering that, besides his curly horn, our guard was armed with a short sword and a revolver, and that the country is as absolutely safe as Middlesex, it occurred to me that the "Tommy" might have been dispensed with, which would enable four passengers instead of two to be carried. But on this occasion it was immaterial; I was the only candidate for a seat.

For a while our road lay along the 


\section{A DILIGENCE DRIVE}

level, and very cold I found it; for I was but lightly dressed, and the canvas walls and roof of the concern provided but little shelter against the nipping air. As a rule I daresay the road we were following is as lonesome as most others in Bosnia, but it was quite otherwise this morning, and every few minutes our sober vehicle had to pull into the ditch in obedience to the frantic shouts of the Turkish driver of some ramshackle conveyance taking a cargo of sportsmen to Kupreš races. Before long they had all left us behind, and the ascent of a steep pass brought our team to a walk. I jumped out and walked on a bit till I had set my blood in circulation once more; and, alternately trotting and walking up the serpentine curves, we reached the top of the pass 


\section{IN AUSTRIAN TURKEY 205}

at last. Kupreš lies high though, and descent there was but little till we reached the town, which presented an air of unusual gaiety. It is little more than a village, and this is the day of the year here. With difficulty I resisted pressing and hospitable invitations to stop, contenting myself with inspection of the elaborately decorated schoolroom, in which, after the races, it was proposed to dance through a long and hot afternoon and evening. On the wall was the programme of the day containing such items as "Czardas" and "Kolo." Somehow the latter evoked irrelevant memories of $\mathrm{J}$. L. Toole. "You should see me dance the Kolo"; nor was it till long after I remember that "Bolo" was his little game. 


\section{A DILIGENCE DRIVE}

By this time fresh team, driver, and escort were ready, and we continued our drive. Crossing the Kupreš tableland we caught sight of the bright-coloured crowd waiting for the races to commence, and then plunged into an ever-winding descent, depending, of course, solely on the screw-brake. At Suića we changed horses again, and down, down, down we went to the great plain of Livno, and drew rein at the post-office of that town. Here my kit-bag was weighed and charged for, and then I was free to seek out the not altogether uncomfortable hotel.

From Livno two lines of post-carts run, one into Dalmatia, connecting as far as Spalatro, and the other to Glamoć. This latter was my goal; but, as a matter of 


\section{IN AUSTRIAN TURKEY 207}

fact, I chartered a ladder-waggon to get there, and thence plunged into wilds where nothing but a Bosnian saddle-horse will go. 


\section{XVII}

\section{MY MOOR}

W $\begin{aligned} & \mathrm{Y} \text { moor is not in Scotland, nor yet in } \\ & \text { Yorkshire, nor even in Wales. Nor }\end{aligned}$ is it a "Tommiebeg"--much rent and little game-for, as a matter of fact, I don't pay any rent at all for it. I wish I did, as will appear hereafter. Nor is it a grouse moor, though it may once have been. There are not even black game on it, though old men have told me they shot them there in their youth, say seventy or eighty years ago, for I speak of men who were old when I was a 203 
boy, and who have long since been laid in the village churchyard. It lies some three miles from, and perhaps six hundred feet above, my old home, and forms part of the glebe of the adjoining parish, by the permission of whose rector I shoot over it. I wish I were the only one to do so, but the same privilege is extended to others, and that is the reason I cannot rent it. I daresay I am the most zealous of those who may go there, for I think I get the most of the shooting. It is not all, strictly speaking, moor, for a good bit at its south-west corner is woodland, -stunted oak cover, with some fir and larch, and much birch,- - but the rest is not by any means all heather, for there is much gorse - too much, indeed, for dogs to work it fairly. Lastly, there is a bit of some fifty or sixty acres which fire has destroyed within I 4 
the last year or two, and which is only bare black soil, with twisted gorse stems and a few dead trees. All, or nearly all of it, is let, though I never dared to ask the parson how much, or rather how little, a man could afford to pay for such stuff. Still, a few halfstarved cows and ponies are sometimes to be seen there. In old days they dug out stone for millstones there, and left a number of nasty holes, which are apt to bring one to grief among the high heather, gorse, and fern. As it is no one man's shoot, it is left, of course, to stock itself, and produces every year two or three nides of pheasants, as many coveys of partridges, and a fair number of stout moorland hares and rabbits. But it is the visitors I value most highly. Woodcock seem to affect it particularly, and although there are not so many snipe as one 


\section{MY MOOR}

would expect from the nature of the ground, they are sometimes to be found there. On such ground, of course, a bag is not to be expected; half a dozen head is a good day's work, even in September, for the partridges often go out of bounds, being mostly bred on the northern edge of the moor, where it adjoins cultivated land.

One bright morning, not long ago, R. and I, with a beater and two dachshunds, arrived at the corner of the ground about ten o'clock. The first bit to be beaten is the edge nearest us-oak covert. I take the outside, and $\mathrm{R}$. a ride in the wood, the beater and dogs working between. Before long there is a yap! yap! Three pheasants rise right in the fence, and I bring one down with a shap-shot as he swings round a young tree. R.'s gun is silent; they have passed him out 
of range. The rest of the wood is blank. At its end is a dismal-looking alder-grown swamp, which holds two woodcock. Both go away wild, and $\mathrm{R}$. gives them the customary salute. Now comes another bit of oak cover. I am on the high road outside, when a hen pheasant sails over and goes away untouched. As I reload my two barrels, a jolly farmer's wife drives past me in a gig.

"Saved his life this time, sir!" she says; and I feel scored off.

That is the only pheasant there, but at the edge where the covert is lower $R$. secures a hare. We now turn to the moor itself. For some time we see nothing, till at last we approach a boggy stream and change our cartridges.

Scape! scape !-Bang !-and R. has him, the only snipe there to-day. A little further 
on, and the dogs get very busy. Whirr! Up gets a covey. Alas! I have still a snipe cartridge in the right barrel, but can and do bag one with the left. The covey goes out of bounds. In the next bottom we cross, R. gets another hare, and as we go on we see a covey of partridges come over and settle in a high gorse right before us. We had a dead mark, but can do nothing. The dogs work about, and presently give tongue, but continuously. For twenty minutes they push their quarry through gorse nearly three feet high and very strong, till at last it (a rabbit) breaks cover across the high road and gives an easy shot to me, who am standing on the bank. By rolling bunny over I much startle a couple of lovers, who are strolling arm in arm along the road a score of yards on, wrapt in one another, and who 
consequently had not noticed us. This is the end of the moor, so we turn back on a parallel higher beat. Presently, R. walks right into the remains of a covey-three birds-and neatly grasses two. The third goes on, and we find him in the next little valley, but too wild to do anything with, as he is off as we appear over the ridge. Well, we are not going in pursuit of a solitary partridge, so we sit down to lunch by a purling moor-rill. Never does ten-year-old whisky taste better than mixed with the moor water, does it?

Lunch despatched, and the post-prandial pipe smoked, we walk on over the burnt ground, and work a lot of oak scrub; but, as we all have to go in, all we do is to hear an occasional yapping, and the rise of several pheasants. I see one of the dachshunds 
work about and push out a woodcock almost with his nose. But, though it is not six yards from me, I only hear the flap! flap! and see nothing. I know what it is, though, and if I didn't the dog would tell me; for these dogs, though clamorous on pheasants, are mute on cock. A little further on, another, or perhaps the same one, rises in a clearer spot, and I pocket him with much satisfaction.

At last only a little piece of covert is left, so we two go on quietly to the end and have it brought up to us. It is blank, though, for these wild pheasants are bad to drive. When the dogs reach us, they become very busy, however, and presently up jumps a fine hare between us, and I miss her, or perhaps not quite, which is worse, for she gets away. Then we turn to our right, and 
go down a swampy dell with birch covertjust the place for a blackcock, if blackcock there were. 'There are none (alas!), but as I go along the far side a fine old cock pheasant rises wild before me and goes rocketting across the glen. I follow him with my eye, till all at once he collapses and falls heavily on the other side. Well done, R.! Towards the bottom the dogs bustle out a rabbit, which I secure, and then we knock off. A brace of pheasants, a leash of partridges, a couple of hares, a couple of rabbits, a woodcock, and a snipe-eleven head-is a red-letter day for my moor, and the variety is charming, making up, to my mind, for much.

All days on the moor are not so good, but we generally get a few head. This was my worst day this season: Began by shooting 
a hawk (I should have said I was alone); then dropped a pheasant with a very long shot, and lost her in thick gorse; another got up in oak scrub, and I missed it with both barrels; flushed four woodcock without getting a shot; then put up a hare in low covert, and, just as I pulled at her, my favourite dog jumped out of the scrub right in line, and got about two dozen shot in her. Then I thought it was time to leave off. Result: No bag (for I forgot to tell the keeper to pick up the hare), and eight and sixpence to pay the vet. However, the dog got over it, so I suppose "it's all in the day's work." 


\section{ON THE EDGE OF THE DESERT}

THE edge of the Great Indian Desert does not hold out any great inducement to the lover of the shot-gun. I mean that no one would think of visiting it with a view to shooting, unless it were for the excellent wild-fowling its tanks provide in winter. But those, whose duties call them there, can sometimes amuse themselves on an off-day nevertheless. A few years ago I was one of these; and in this paper I propose to describe such a day. "Half218 


\section{EDGE OF THE DESERT}

day" would, perhaps, be a more correct expression ; for a cloudy late autumn day had more than half passed before my tonga came to the door. (A tonga, I should perhaps explain, is a low two-wheeled dogcart drawn by a pair of ponies, and capable of traversing the roughest of ground.) My wife took the ribbons, I sitting next her with the twelve-bore between my knees, and off we rolled. For about three miles we stuck to an excellent road, and then turned off to bump across the plain for two more. These plains are mostly sandy and undulating, the higher ground being rocky. The principal vegetation consists of thorn bushes, and cactus. Here and there, surrounding a well from which they are irrigated, are clumps of cultivation, mostly cotton or maize. On our way we passed several great flocks of blue rock- 
pigeons, feeding unconcernedly at a few yards distance. I resisted the temptation to "brown" these, even though one contained what I had never noticed before-an albino bird. These pigeons roost in the wells, where they are easily caught by the natives, who, having quietly thrown a net over the mouth, make a noise, whereat the birds fly into the meshes. In this way the regimental pigeon-shooting club is easily and cheaply supplied. We also saw a couple of the little desert foxes trotting unconcernedly along. Although they are little bigger than rabbits, they afford rare sport with greyhounds, and are consequently sacred from the gun.

At last we reached the appointed place, where my shikari and a coolie were awaiting us. Posting them and the pony-boy in an 


\section{OF THE DESERT}

extended line, of which the tonga was the centre, we proceeded to beat the ground before us. Before long a signal was made from our flank. I got out and walked to the man, but only to have a cobra pointed out to me, lying on the sand with half-erected head. I know no more devilish-looking brute than a black cobra. This one was dark as jet, and a good six foot long. I promptly blew his head off, and returned to the trap.

The next signal was from the shikari, who pointed out several partridges running before him. I followed quietly till they went to the right of a large clump of cactus, when I sent him after them, taking the left myself. By walking smartly I met them face to face at the end, just as I had calculated; and they rose, enabling me to get an easy right and left. The grey partridge is said to be a 
scavenger, but some people eat them nevertheless.

The next shot, some time afterwards, was out of the trap, the ponies being used to this. A covey of sand-grouse got up just before us; and one of my two shots was a kill. The plumage of these birds matches so exactly with the colour of the sand they sit on that it is practically impossible to see them on the ground. Except for their feathered legs they look more like a pigeon than a grouse.

The next proceeding was to beat a cotton patch that lay in the line, for which purpose I got out, and we walked through it. It only held a hare, which jumped up a yard in front of me and dashed back. I let her go far enough and then rolled her over.

So the afternoon wore away. I had more shots, successful and otherwise, at 
partridge, hare, and sand-grouse. The prettiest of these was one at a sand-grouse, which, put up at the end of the line, came straight over my head, high and fast, but did not save himself on that occasion.

We beat one or two maize fields. Some yielded a hare; some only a jackal; at which nobody, I should think, would shoot. The men were beating one of these fields towards me, when, almost on its near edge, a large bird got up with a bustle, and came dow $n$ with a thump. It was a florican, not uncommon in the rains, but a prize so late in the year. The great bustard, which is also excellent eating, is found in these parts, but must be stalked with a rifle. So must the huge sarus crane, of which, by the way, we saw a few solemnly walking about this afternoon. Of "small deer" we 
also saw a mongoose, a Manis or scaly ant-eater, a tortoise, and some huge lizards, -all common objects of these plains. The uninitiated would not believe what a noise a small tortoise makes. When driving big game in this part of the world I have been deceived into expecting deer by a tortoise coming along. Pig, which we did not see, as they spend the day in the thickest covert on the low hills, are also common, and do much damage at night.

Just as we were beginning to think of knocking off, I espied three chinkara (gazelles) some way ahead, and determined to try a drive. For this purpose I crept along a nullah, and reached a cactus patch beyond them and skirting a depression along which I thought they would come. When they had given me sufficient 



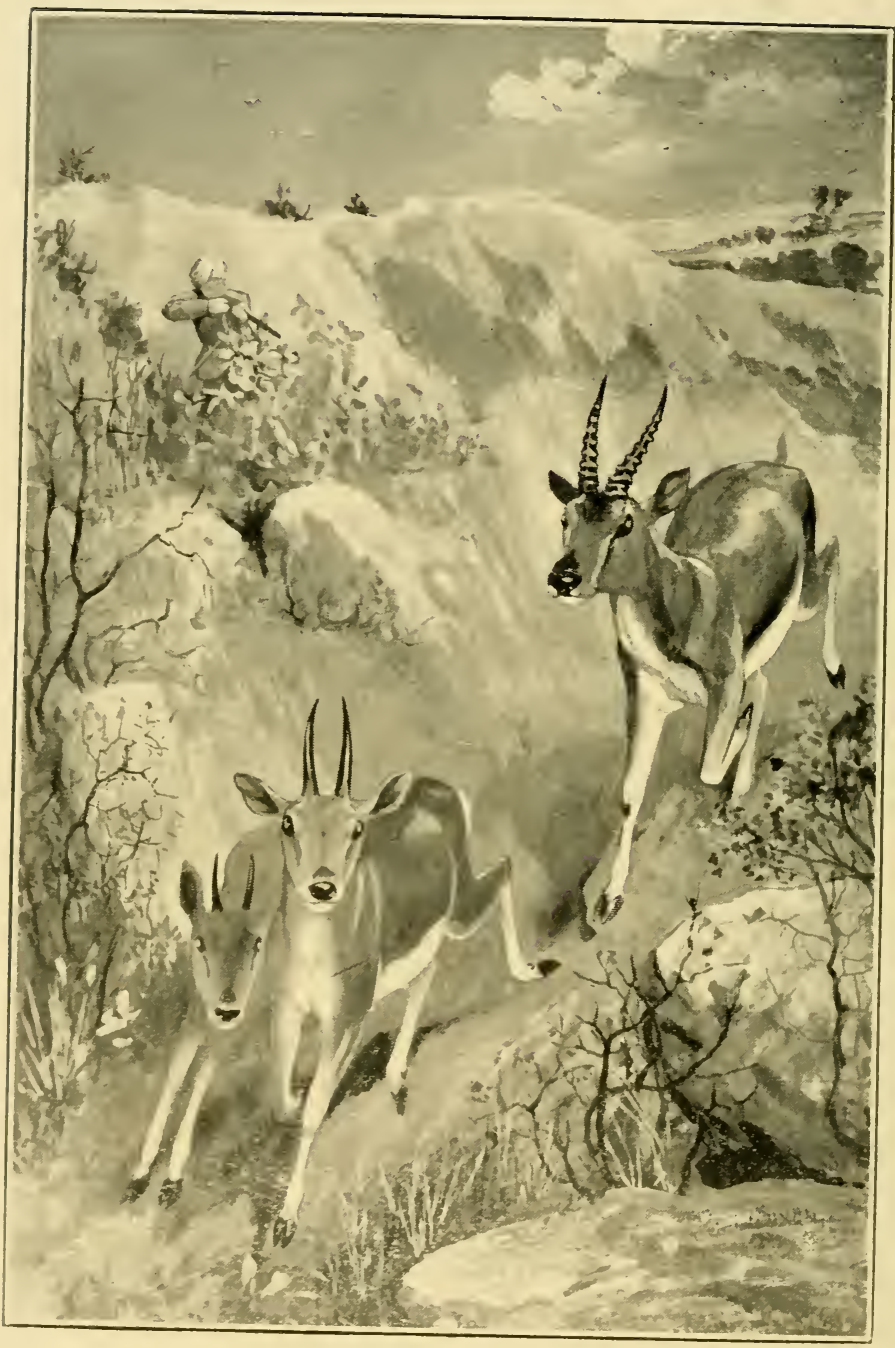

MAKING SURE OF HIM 


\section{OF THE DESERT}

time the beating line with the cart moved carelessly on, not towards the animals, but diagonally across them. This sent them off; and by degrees they worked towards my ambush.

I, of course, could form no idea of what was going on; and had very nearly concluded that the bundobust had failed, when I heard the rattling of stones, and the animals filed past, the buck bringing up the rear. I kept very quiet till he was close; and then, making sure of him with my only No. 2 cartridge, I had a snap-shot at the doe with my right (cylinder) barrel, which was loaded with ball. She turned a complete somersault to the shot, but before I could get to her, was up and off like the wind, after her offspring, which I ought to have said before, was nearly as I 5 
big as herself. Otherwise I should not have fired at her.

On examining the spot I found no blood; but, some twenty feet on, I found a horn, cut off nearly at the base, which accounted for the performance, and proved what a remarkably bad shot mine had been. Still, it should take a pretty "tall" performer to put a bullet in the right place on a galloping chinkara with a smooth bore!

However, the buck was all right, and was soon gralloched and secured to the trap.

This ended the day's shooting, and we drove on to an old tower, erected once in order that the then lords of the soil might shoot tigers in safety from its top. There are as many tigers in Epping Forest now as there are in that district. Here 


\section{OF THE DESERT}

our Arabs were waiting; and, mounting, we cantered off homewards. Before we reached the cantonment we heard "Retreat" blare out. The sun had disappeared behind the purple western hills, which divided us from the desert. 


\section{I X}

\section{ENGLISH AND GERMAN SPORTSMEN}

SOME half a dozen years ago I wrote an $\checkmark$ article with this title for the Field, which I do not reproduce bodily here for two reasons. The first is that then I only knew North German sportsmen, whereas I have since then become acquainted with those of Southern Germany and Austria. The second, which is even more important, is that during these latter years I have become sensible of a rapprochement in their methods towards ours in several ways, and in ours 
towards theirs in at least one, and this I look upon as too important a matter to pass over in silence.

In that article I remarked, and truly, that " the days of curly horns and hunting-knives in Germany are gone" ; and went on to say that "in his dress the German sportsman would hardly be remarked at an English shoot, except perhaps for the cut of his gaiters." Now this is true of North Germany; but in the South and in Austria it is not so. There the sportsman sticks to a sort of grey-green tunic with horn buttons, bright green facings, and a stand-up collar, and never fails to ornament his puddingdish-shaped hat with a bunch of blackcock's feathers, or a tuft of hair from the chamois' withers. Very often a brooch set with fox's or stag's teeth secures this. 
This dress is not confined to any rank or class, like the German Emperor's hunting uniform. Emperors and kings wear it, it is true, but so do the humblest sportsmen.

The next few paragraphs of the article referred to seem also of universal application, so I quote them in extenso. "The German sportsman's gun, however, would at once single him out by the sling. Here I am inclined to think he has the pull over us. Having tried it, I may say I consider it is never a drawback, while it has many advantages. Unless his gun is at the ready, or over his arm, he always carries it slung on his shoulder, nearly always the right one. Should he want to fire, he seizes it with the left hand, and it at once falls into what the drill books call 'the ready position.' When 
there is no chance of a shot, he sometimes slings it on the left shoulder, or even muzzle downwards. As a result, I do not think I have ever seen, at a German shoot, a gun pointing at another sportsman. When slung, it either points straight into the air, or down to the ground. I cannot say that all my English reminiscences recall equal freedom from danger.

"Again, every German sportsman, except at very big shoots, carries a game-bag. This is a more or less gorgeous affair, generally fringed with string lace, and of considerable dimensions. Well, there is a reason for this too. It is not the custom of the country to give shooting lunches, consequently each sportsman carries his own. The bags are generally divided, so that a bird can be put in separate from either lunch 
or cartridges. Then there is a pocket for game licence and any small articles.

"In the matter of cartridges, there is also a great difference between English and German sportsmen. An Englishman put his cartridges into his bag indiscriminately, and they are all generally one size shot, probably No. 5. A German, on the other hand, has to provide for various contingencies; I am now alluding to covert shooting. He can never tell that he will not see a boar or a roe-deer, and in some parts a stag too. His principal game is hare, but he may meet with woodcocks or hazel-hens. Consequently, he is generally provided with half a dozen kinds of cartridges, ball and buckshot for pig or stag, Nos. 2 (or 3), and 4 for hare, fox, and roe-deer, and 6 for woodcock. The usual charge is 4 in the right barrel, and 2 


\section{GERMAN SPORTSMEN}

(or 3) in the left. Should there be any pig about, he at once reloads with buckshot in the right, and ball in the left; and if a cock is flushed and marked down, in goes No. 6."

Most of the rest of the article relates to roe-deer shooting with beagles, and I omit it because I have so often and often had my say in print on this matter. Moreover, an excellent account of the sport as practised in Scotland appeared last year in the Badminton Magazine, from the facile pen of the Hon. A. E. Gathorne Hardy (who, by the way, writes me, "I have been shooting and watching roe for the last thirty-five years"), and also, anent an old favourite idea of mine, a Roe-deer Preservation Association. " "I shall be

${ }^{1}$ An association of landowners and sportsmen interested in the preservation of roe-deer. Landowners to undertake to turn down and preserve roe, others to promote legislation, etc., etc., for their preservation. Whilst quite agreeing with 
very pleased to join such an association as you suggest, but my experience as a legislator suggests a doubt whether it will be easy to pass a measure for the protection of roe through the House of Commons."

But to return to our sportsmen, and specifically to the points in which we are drawing together. Well, of course, one point is the very heavy drafts the Germans have, in these later years, made upon our pointer blood. We, on our side, have made great advances in the matter of retrieving pointers and setters, and surely this is adopting the German idea, that to keep a pointer or

Mr. Gathorne Hardy's anticipations of legislative difficulty, I think I have to a certain extent met the case in my paper, "Poor Pussy," in which it is suggested that Parliament be only asked for a Wild Animals Act, giving County Councils similar powers as they now have in the case of wild birds. 


\section{GERMAN SPORTSMEN}

setter, and a retriever, is to keep two dogs to do the work of one.

Several things that seem ancient history to us are making their way but slowly into Germany. Such are the hammerless gun, nitro-powders, and shot-and-ball guns. On the other hand, some deer-forest owners here are beginning to see that to systematically shoot as many of your big stags as you can, and the biggest for choice, before the rutling stason, is to certainly deteriorate your stock of deer. 'The German shoots his stags in the rutting season, and consequently many do not die till they have left their mark among future generations. Many Scottish forests are let with the reservation: "No stalking after October 15," whereas in my opinion, "No stalking before October I," would really profit the owner more, and 
perhaps not hurt the tenant, who certainly would get no heads partly in velvet. The present system makes for meat, no doubt, but what stalker would not rather kill a royal than a six-pointer twice the weight. Perhaps some day Highland landowners will see this, and also see how the stock of black game benefits by the spring shooting of cocks only in Germany.

Here again is a great difference between us. The German's gun and rifle are hardly ever idle, and yet he shoots essentially as a sportsman, i.e., for the good of his game. In autumn and winter he shoots as we do. In spring he shoots woodcock, as they pass northward, blackcock, and cock capercailzie. May only sees him idle; in June the roebuck's horns are "clean," and he begins stalking them. In July his flappers (earlier than 
ours) afford him amusement, and in August the quail, and in the south the partridge.

The most astonishing conversion to English ideas is perhaps contained in a letter I received the other day from an Austrian friend, who says, "Everybody here is giving up their I6-bores for 12's. I am going to myself."

My original article contained a comparison of the position of the fox in England and Germany. But in these last half-dozen years it has become manifest that in many English counties Reynard is tottering on his throne. Still we are a long way from German methods with him yet. The remarks with which I ended it are as true in my experience then as now, so here they are.

"In conclusion, there is one point which I must not omit, even though it tells against 


\section{GERMAN SPORTSMEN}

us. Even nowadays, an Englishman has only to live in a country neighbourhood in Germany for a few weeks to get as much shooting as he wants. Not only will he be readily asked everywhere by all classes of sportsmen; but a place of honour in the beats, on a favourite game pass, will be assigned to him, and all will express regret if he does not get a shot. If he does, he is, of course, expected to hold straight. The conditions of English country life are different, but certainly a German might live long in an English country town before anyone would offer him a day's shooting, unless he had introductions. It is true he would be free and welcome to hunt with the local hounds now and again, after which the secretary would probably be down upon him for a subscription." 


\section{XX}

\section{IN ALBANIA}

" RE you game for a couple of days at the pig, next week?" asked $H$. of me one January afternoon, when we happened to meet on one of the muddy Corfiote roads.

"Why, certainly," I answered; and accordingly we made preparation. There was considerable difficulty that winter about shooting permits for Albania; but this was then mostly at an end. The weatherincessantly wet since the middle of November 
- was as favourable as could be, as the marshes were bank full, and the pig consequently driven to the hills. The only thing against us was the fact that an American had been harassing the game pretty continuously for the past two months or more, not only by fair driving (to which nobody could object), but by serving out a number of pistols to his beaters. The row they made with these, no doubt, gave him every chance of a shot, but also inspired the average pig with a strong desire to shift his quarters, especially when it had been pretty frequently repeated. In countries where shooting is free, and many men shoot, especial consideration should be bestowed on other sportsmen, and one should be guided by the unwritten laws of sport, in default of enacted game laws, as I think I may say all those who shoot in 
Ladakh or Baltistan are. I have drawn attention to this point for the benefit of those who may take an Albanian trip in the future; and will now return to my subject.

All arrangements being made, the Olive, the crack ship of the well-known Woodley fleet of yachts, cast off her moorings about three o'clock one Wednesday afternoon, having for passengers, H., myself, and wife. Wind there was little or none, and dinner was over long ere the anchor was let go in the little roadstead of Tre Scoglie-so called, for no very clear reason, because there are really five islets.

Next morning, H. and I, with Lorenzo, the skipper of the boat, who was also to captain the beaters, landed in the dinghy about nine, and half an hour's walk brought us to our 
stands, which were pointed out by old Kollio, the Albanian, so well known to all who have shot here. The beat was a short one. For a moment we had hopes, but the shouts were only due to the successful attempts of a deer to break back, and all that passed the guns was a fox, whom $\mathrm{H}$. very properly spared. We now started back towards our landing place, and in a bottom Kollio posted us again, H. in a thicket, and myself in an open glade beyond.

By this time I had seen a good deal of the ground, and practically made up my mind we were on a wild-goose chase. It was not without some experience of the matter that I thus expressed myself in a recent work : ${ }^{1}$ "The boar loves quiet, and is assuredly not ${ }^{1}$ In the Land of the Bora, p. 370. 
to be found where flocks and herds wander." But true as this is of the boar of Northern Europe, local conditions have quite altered the habits of the animal on the Albanian coast. Throughout the day we were surrounded by live stock: the infernal din of their bells spoilt all my pleasure in most of the beats, and yet seven or eight pig were forthcoming. But I anticipate. This time, finding my glade gradually filled with horses, donkeys, sheep, a man talking with a boy, and an enormous white dog of sinister appearance, I gave it up, and, as the beaters were still out of earshot, I went back to $H$. and Kollio, which latter posted me in a glade, not very open, on the other flank of H.'s position. The beat was long, and appeared somewhat stragglingly performed. First a spaniel came to me, but I stoned 
him back into covert. Then came a hare, and then a roe. I walked quietly to the left when this appeared, but could not get a clear shot, and withheld my fire. Herein I was right, for very soon after the shouts of a shepherd on the hill drew my attention to a stumpy black body going best pace outside the upper edge of the cover. I ran on to meet the pig, but, unfortunately, I did not know the ground. All I saw was a black shadow through the thorn bushes, when five yards further would have given me a certain shot. By this time it was pouring, and I was glad to get into my cape and make my way back to H.'s stand to lunch. Here I heard that several pig had broken back, and also that the beaters had come on a fine dead boar, shot about a fort- 


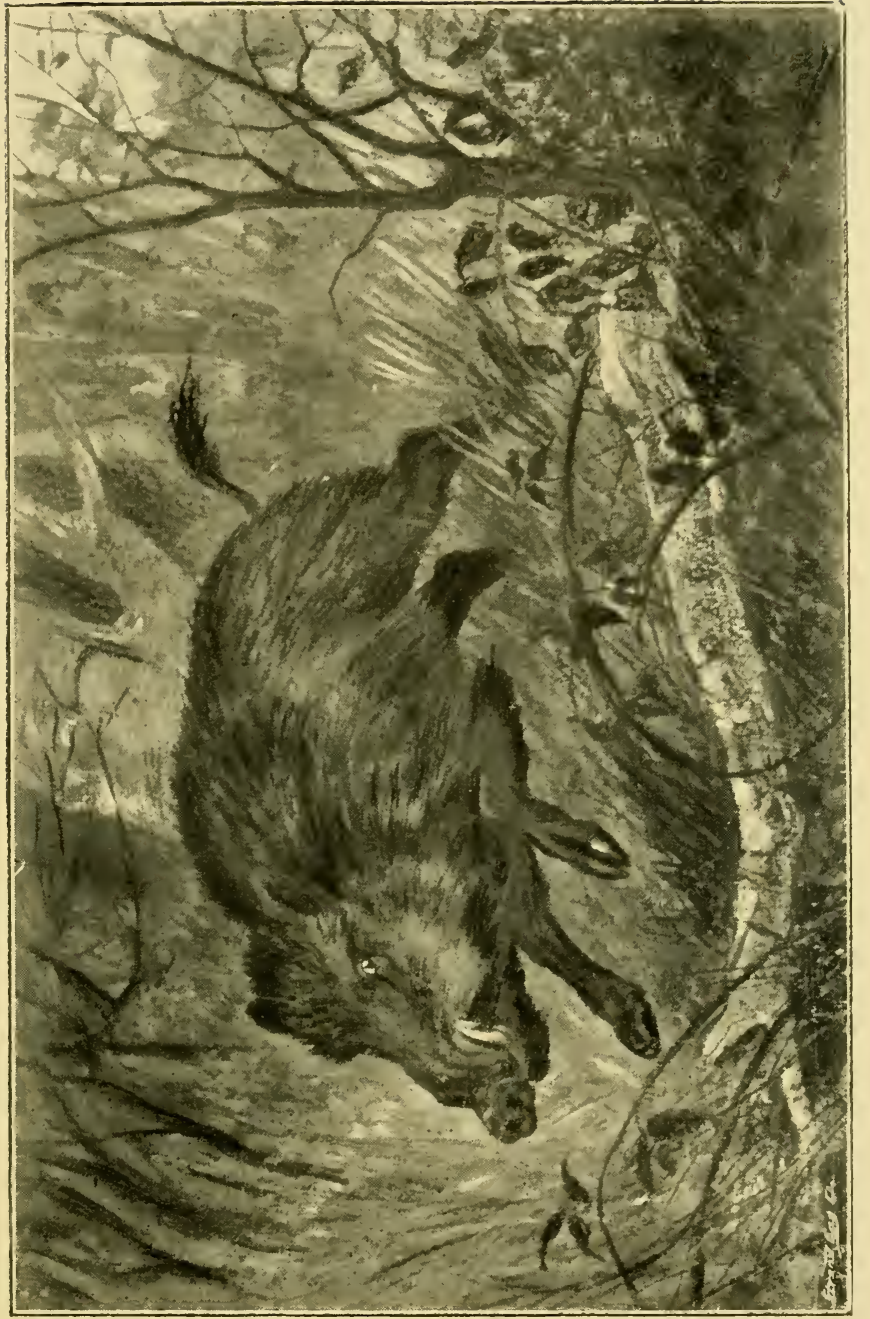

$w$
$u$
0
1
0
4
0
0
2
0
0 
night before, of which the tusks were produced.

Our first after-lunch beat resulted in a comical error. I quite misconceived the position, being in a narrow ride between two patches of thick covert. I faced to windward, of course, and, in fact, was smoking, when suddenly the beaters opened behind me, and at once their yells and the dogs' notes announced "pig on foot." Of course, they (there were two). broke back; and I am convinced that this was only one of many times on which Kollio's dispositions failed, from his neglecting to consider the wind. However, we were both posted in a hollow road so narrow that it would have taken a first-class rifle shot to make sure of a pig. For the rest of the short beat, woodcock kept flap- 


\section{IN ALBANIA}

ping over my head in a lazy and tempting manner.

After lunch, we had to walk some little way to our positions, which, being on an open hillside, would have been excellent for shooting, but, unfortunately, the beat was entirely blank. After this we did little more than turn round whilst the men beat a belt of thick covert running down to a lakelet with marshy banks. Unfortunately, this side of the hill was much more covered with thorn bushes. The beat was approaching its end when I caught sight of a boar passing some hundred yards below me. I could see little more than the withers, but there was little chance of a better view, so I took a snap-shot, the only effect of which was, as the tracks subsequently proved, to increase his pace; but the shot was followed by ear- 
piercing shrieks from three girls gathering brushwood three hundred yards away. As one of them was on the ground I naturally was much alarmed; but when they had scored off me sufficiently they gathered their bundles and walked off.

Shooting here requires great care. I subsequently discovered three horses in the direct line in which I had fired. The next, a short beat, blank of all but woodcock, brought us back to our landing place, and then we proceeded to beat the covert that ran down to our posts in the first after-lunch beat. Dogs and beaters were soon in full cry, and by the sound of the former, the pig must have crossed within fifty yards of me.

Directly after I heard a shot from $\mathrm{H}$. The beaters were silent, and, thinking the beat was over, I walked down to the sea. 
A minute after, the dogs we had brought on the yacht opened, and as I turned to the covert a roebuck broke. Forgetting that my right barrel was loaded with slugs (in which I have at any time little faith), and consequently useless at a range of nearly a hundred yards, I fired it. The deer changed his course, giving me a broadside shot for the bullet, and then disappeared in the thicket. Presently I caught sight of him going up the wooded hillock, and, detecting an abnormal movement, I ran after him and found him lying dead. The 20-bore shotand-ball gun had done its work well, the wound was just behind the shoulder. $\mathrm{H}$. now joined me. He had run on to where I was originally placed in the second beat, and the pig had crossed the open glade but one hundred and fifty yards from him, and 
at that range his smooth-bore was naturally ineffective. My roebuck - a small onewas, of course, in velvet.

Next morning we started for a long pull in the gig through cold driving rain and over a rough sea. H., who is a first-rate swimmer, kept explaining what he would do if we were swamped. As I am better on land than in water, I felt this conversation the reverse of cheering, especially as I could not light a pipe. Fortunately, we landed safely below the monastery which gives the point its name, and climbed the hill to the shore of the great Butrinto Lake. The day was too thick for the scenery to be at its best; but every now and then we caught sight of snow-clad mountains and of masonrytopped hills; but which of these latter was the "lofty Buthroton" of Homer, I canno 
venture to say. The first beat only produced a roe, which broke up over the ridge unshot at, passing right through a line of woodcarrying women. The lake was covered with duck, who well know they are safe there. For the next beat we crossed over to the sea, and came on the same roe in doing so. I snapped at him, but fruitlessly, at about one hundred and fifty yards; and nothing but this roe was found in the beat, when, needless to say, he broke back. All that passed me was a wild cat, at which, of course, I did not fire. Then followed a small and unpromising beat, which was quite blank. During this our party was reinforced by a sulky-looking zaptieh, who had not even a good-day for us Christian dogs, whose two francs he would, however, have pocketed at the end of the day had we not 
got rid of him by a stratagem. For the fourth beat we had a long and rough walk along the lake, but, not long after we were posted, shouts were heard, and we were requested to move towards the sea, an enormous solitaire having been seen that way. He had moved off, however, and we ate a somewhat depressed lunch. For the last beat we had a long walk on the rocky shore and then across to the lake again. In this beat there were nine pig, but all broke back; and we went to our floating home disgusted.

Saturday was as unpromising a day as any other. E. accompanied us, and we landed at the nearest point and walked off to the lake again, the first beat being a continuation, so to say, of the last of the night before. A fine fox came down to the 
rocks by me, and I let him go, but my forbearance was not rewarded. The only pig in the beat, as usual, broke back. Most of this beat took place in driving hail, and it was bitterly cold. The next beat up to the ridge was quite blank; all I had to look at being a swan flying over the lake. The third was the same as the fourth on the first day. Hardly were we posted than two jackals passed me. I was bloodthirsty by this time, but missed one at short range, and, rightly or wrongly, put it on the slugs - seven of which form a charge, and consequently cannot be expected to do much in the way of a pattern. In the next beat there was again a jackal, at which E. snapped with her Derringer. I had heard much of Albanian "jacks," and their large size, but these were no bigger than our 
Indian friend, but more yellow. The fifth and sixth beat we had already taken the first day, and both were blank, save of woodcock.

Next day's daylight saw us under way for Corfu, unanimously agreed that we had had the worst of luck, but congratulating ourselves at having, at least, no discreditable misses to own to.

Now, at the risk of being told that every fool is born a critic, may I be allowed to point out the reason why we failed, and why everyone is likely to fail who goes to Albania boar-shooting, and puts himself unreservedly in the hands of the natives. First, it is almost unnecessary to say (as I have said it in print before) that, with the sole exception of the wolf, the boar is the most difficult animal to drive; and yet there 


\section{4

is hardly any other method of bringing him to the gun. The best of all, the baying him with a dachshund, and creeping in for a shot, however successful in German forests, would not ever succeed in Albanian thickets; although that development of it, when one sportsman posts himself on the opposite side to that on which another tries to steal in, possibly might. Given, then, that driving is a necessity, how should it be conducted? First, and perhaps most important of all, the greatest attention should be paid to the wind in posting the guns. Secondly, there should be no admixture of dogs and men; the former, perhaps, running a hare or fox half a mile ahead, and actually turning back pig that the beaters have started in the right direction. Of the two, and only consulting my own taste, I would prefer working the 
coverts with two couple of slow musical hounds (such as bassets ì jambes droites, with one man to hunt them) to any number of beaters. Thirdly, if beaters are to be used (and few will have hounds with them in Albania to avoid this necessity), let them leave their dogs at home and go silently. The occasional tap of a stick or a whistle will move the pig fast enough. In urging this, I am only repeating a sportsman's axiom which applies to all sorts of game, but the result of its application in Albania should be phenomenal. I firmly believe that every pig along its seaboard knows that fiendish yells, shouts of Darramos, and yelping of curs, simply mean danger in front, and breaks back if he can. Lastly, of course, a sufficient number of guns to cover the ground should form the party, the nature 
256 IN ALBANIA

of the ground often preventing one from covering fifty yards. By only being two, we lost three distinct chances the first day; in fact, all the pig that came forward at all. 


\section{XXI}

\section{SHOOTING-LADIES}

I F I am old-fashioned enough to think

1 the fair sex much more in their place by the fireside on our return from hunting, than scratching their faces, spoiling their complexions, and risking limb, if not life, by our sides in the field, I am just enough to admit that there is something to be said on each side in that case. Fishing, again, is a sport, against the participation in which by women it is difficult to say more than that they might 


\section{8 SHOOTING-LADIES}

be better employed. When we come to the gun, however, I must say I cannot be so moderate. Of course there are positions which, with some guns, do away with the idea of "killing" and suffering. We all know men who stand out on the covert side and kill their pheasants bird after bird dead, so that the animals meet an instantaneous, and, as far as we know, painless death in the air. We are not all like that, and sometimes we must own to a bird off "with a leg down," or a "runner." Now, we men don't trouble to devote much thought to the feelings of that "runner," as, having gained some hedgerow or similar shelter, he watches the retriever approaching him with his unerring nose on the line; or that of the other bird, which has cowered when he 


\section{SHOOTING-LADIES}

alighted with one or both legs broken throughout the long winter night till the next noon, when the keeper comes round with his dog to look for "lost birds." Nobody expects a shooting-man to make a fuss about the hare he was a "little behind" on, and when he picks up the squealing animal his only idea is to put her out of her pain without unnecessary delay. We have a comforting theory, which may be right or may be wrong, that "the lower animals don't feel like we do." I hope we are right, but anyhow man's primeval occupation was the chase, and I don't think anyone will be likely to couch lance against us sportsmen if we follow our sport in a sportsmanlike manner - as old Bishop Sinesius said, "because it gives us endurance, prompt. 
ness, courage, self-control, as well as health and cheerfulness."

Now, some of the above-named qualities are no doubt most desirable in women, but I venture to think they are to be obtained otherwise than with the gun. Endurance and courage (other than moral) we don't expect in our wives and daughters. Self-controlled, healthy, and cheerful women we meet daily, who neither hunt nor shoot.

But if I don't like shooting for women, there is one form of it which especially raises my bile. I refer to deer-stalking. Every autumn we read in the papers how Lady A., Mrs B., or Miss C. has "bagged a royal," or "grassed a nine-pointer."

Now, I consider a man but half a sportsman whose joy is not tempered with 


\section{SHOOTING-LADIES}

regret as he leans on his rifle beside the monarch of the glen; and it seems to me, a feminine (as distinguished from a female) mind should feel the regret but not the joy. And then the butcherly details. I suppose the "fair riflewoman" does not assist in the gralloch; but are there no such things as the life-blood running from the wounds caused both by bullet and stalker's knife - the painful last contractions, the dying limbs, the glazing eye? I think such sights are not for women; and to show that I am not alone in my opinion, I will quote one scene from memory. It is nearly ten years ago, and the Devon and Somerset Staghounds have set up their stag in a small pond, traversed by a flight of rails, at Barnsworthy Farm, near Faịfield, on the Quantock 


\section{SHOOTING-LADIES}

Hills. A rope is quickly thrown over the animal's horns, with which he is drawn up to the rails, and Arthur's ready knife is thrust into his broad chest. The blood rushes out in a great stream, but the poor stag makes no sign but a moaning bellow of pain. Silently most of the sportsmen turn their horses round in the lane, and move off to empty flasks and light cigars farther off. For several minutes, I am told, the poor beast stood so, his legs gradually beginning to shake, till he fell down with a crash. Throughout this time a young woman remained quietly sitting on her horse, and looking on, within five yards of the animal.

"Did you ever see anything so sickening as that girl's conduct?" said one sportsman to another in my hearing. 


\section{SHOOTING-LADIES $\quad 263$}

"Never in my life," replied No. 2.

And every man present agreed with him.

Women of England, think of this before you submit yourself to like criticism. 


\section{XXII}

\section{SHOOTING-RIGHTS OF SMALL FREEHOLDERS}

THE question, from a sportsman's point of view, of the shooting-rights of small freeholders is not equally burning in all parts of England. In my old westcountry home it is, and I believe it is so in Wales, while in the eastern counties it hardly enters into the list of game preserver's unpleasantnesses. Still, I take it, it would be difficult to find many parishes in England and Wales where there are not 


\section{SMALL FREEHOLDERS 265}

one or two cottager freeholders, so I may fairly consider it a matter of general interest.

Now, I should like to begin by saying that I am the last man in the world to attack any vested interest, or to make what may be called a class distinction between landowners. Therefore I maintain that unless I can show that the sportingrights of small freeholders are (I) prejudicial to the community in which they live, (2) honestly useless and even injurious to themselves, and (3) contrary to the wisdom of other countries, gained by experience, I am not justified in raising, as I did in the Field a couple of years ago, and as I do here to-day, an outcry for the legal abolition of those rights. I will now take these heads in order, but before doing so I 


\section{SHOOTING-RIGHTS OF}

will just glance at the position and the line of conduct of a good many small freeholders-those, in fact, whose action has served to point out the objectionableness of their existence as owners of sportingrights. A. B. owns rather under one acre of land, inclusive of that on which his cottage and pigstye stand. It is, of course, garden ground. One side of it skirts a road, but everywhere else it is surrounded by Mr. C.'s pheasant covert. Now, gardens contain many things dear to a pheasant's palate, not to speak of the little patch of buckwheat we so often see in such places, which tells so plain a tale. Now, by the law of England, A. B. has exactly the same rights as the squire. He can, provided he take out a game certificate, shoot, wire, or otherwise take every pheasant he may 


\section{SMALL FREEHOLDERS}

see in his little garden, however unfairly (mark this) he may have attracted them there; and even if each bird has a wire ring on its leg to show that it was bred and brought up at great expense by Squire C. and his keepers, for the pheasant is ferce nature. Well, this is his right, and we must respect it. But who does not know the oft-repeated story? A market is found at the village pothouse for an illegally wired bird, illegally, because A. B., of course, never takes out a game certificate.

"Cawn't ye get us a few more?" says the game receiver. "'Ere, I got summat in the cawrt." And he hands over to A. B. a quart or two of damaged raisins. "Chuck a 'andful over the fence," he is told, "for a day or two, till the birds begin 
to find 'em. 'Then put the rest in your gawrden. Nex' day put down the wires, on your own land, mind, and look out nobody sees you take 'em up. I'll be 'ere agin Monday." Very likely the keeper fences in the covert; but the netting is always getting trodden down. "I dunno anythink about it," says A. B., who is fast becoming a professional poacher. Even if it isn't, I need not tell the reader pheasants will stray, even over netting. There is only one thing to be done. Every attempt is made to keep the birds away from that part of the wood. The keepers are always running dogs over it, or sending old women to gather dead wood. Perhaps the desired result is obtained; but Squire C. loses the shooting of a score of acres because A. B. has that of a half one. What does the 


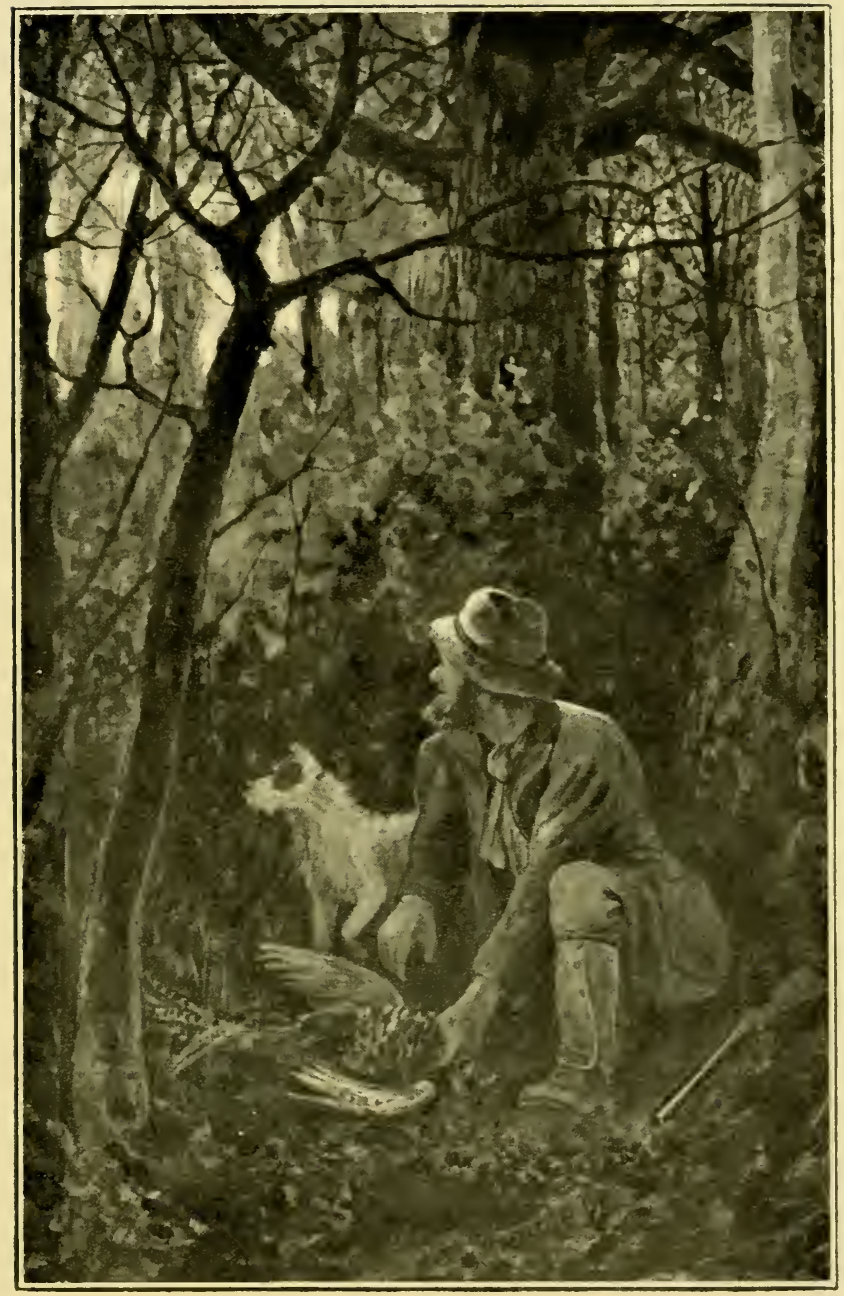

FAST BECOMING A PROFESSIONAL POACHER. 



\section{SMALL FREEHOLDERS}

latter do then? Perhaps he gives it up. Generally, though, he has got a taste for easily earned shillings, and follows the pheasants. He is caught at last-again and again. The option of a fine is at last not given, or he is caught at night. Imprisonment follows-the community is put to expense. He comes out worse than he went in; ready for any crime. "A dangerous fellow!" says the squire, and he is right.

The keeper has another case-almost worse, he thinks. D. E. owns an acre or so right in the heart of another covert, and has a right of way thereto. He takes out a ten-shilling gun licence, and, gun in hand, walks down through the wood under the keeper's nose every morning. Within ten minutes a shot is fired. The keeper hurries 


\section{0 SHOOTING-RIGHTS OF}

down, and finds D. E. beginning solemnly to "get up 'taters."

"Yes, I shut," he replies. "Quest ${ }^{1}$ it was. I missed un, though." Now what is the keeper to do? He is pretty certain the man's quick eye caught sight of a pheasant running out of the potato patch, and that this bird now lies dead amongst the potato haulms, probably with a shovelful of earth over him. Killing game without a licence, no doubt. But a search would be fruitless, as would be an examination of the first basket of potatoes taken up. If he waits, the bird will remain till it rots, if necessary. Besides, how can he wait? If he goes, it will go up to the cottage, perhaps by the wife who brings the dinner. Besides, he may be all wrong. D. E. 
would certainly shoot at a pigeon if it crossed his potato patch. The keeper has a shrewd idea that the bird, besides being one of his own rearing, was shot on the squire's ground as D. E. came down the path. What can he do? He cannot devote his whole time to one man, nor escort D. E. every time he passes through the wood. Only one remedy; drive away the birds, and here, the wood being all round the garden, a good deal more must be sacrificed than in the previous case. These two are authenticated cases within the writer's experience. Now let me go back to my premises. I maintain that the existence of such a state of things is prejudicial to the community, not to speak of the cost of law proceedings, the expense of poachers' imprisonments, the moral de- 


\section{SHOOTING-RIGHTS OF}

terioration of the rising generation. I know places where the existence of scores of such landowners (save the mark!) makes preserving impossible. The gentlemen's houses stand empty,-for those who want a country house like some shooting, - and does this mean nothing prejudicial to the community? Ask the butcher, the baker, and the farmer. Ask the poor!

That such rights are honestly useless to the freeholder himself no one can deny. What head of game can a man have on an acre, two acres, five acres, ten acres? Will it ever be worth his while to pay three guineas for a grame certificate to legally take his own? Answer: No; not even including other people's, which will fairly (i.e. without feeding) stray through the fence. That this right is injurious to 


\section{SMALL FREEHOLDERS}

such men, the career of A. B., as above sketched, proves. But even say the man does not turn poacher, that at the most he only illegally takes a pheasant or two in the year, and pops them in the pot for his own supper, how much better the feeling, as he "shoo's" them out of the garden, "I needn't feed ye, anyway, though I do get paid for ye. There's a tidy few birds about. Shouldn't wonder if we got two shilling an acre next letting, let alone the money for beating."

At this point I can fancy the reader putting down this book with the remark, "The man must be mad. Who on earth would pay two shillings an acre for cottage garden shooting, which proverbially holds nothing?" The figure is high, I admit, but the shooting is good when every I 8 
freeholder is a gamekeeper. "What the d-1?"

Let me explain. England is practically the only European country where the small freeholder has any sporting rights. In Germany no owner of less than two hundred acres has; in Austria it is one hundred and fifteen acres; in France, eighty acres. France is a bad country to imitate in other respects, as far as game laws are concerned. Let us take Austria, with the proviso that as far as the general law goes that of Germany is similar. Here the land must be in one parish (gemeinde), or, if in two, then contiguous. If divided by a highway or river, the divided halves must in some degree face one another, so that a man could not say, "I've got thirty acres here, and the rest five miles down 


\section{SMALL FREEHOLDERS}

the river, but only the river divides them."

All lesser properties are lumped with the communal (i.e. common) lands, and the shooting over all these is let by auction every five or seven years. The money obtained therefor is taken by the commune, i.e. goes to reduce the local taxation. Therefore, every taxpayer (not only every freeholder) has a direct interest in the game preserving, because the more game killed the higher price the shoot will fetch next time, and the lower will be the local taxes.

Now, this is the system I want to see introduced in England with certain modifications. I would bring under this system all land (other than garden or ornamental grounds) possessed by any person whose 


\section{SHOOTING-RIGHTS OF}

property in that parish, or in an adjoining one (the land being conterminous in this case), did not exceed one hundred acres. The right to shoot over all these small freeholds and copy-holds should be vested in the parish council (or meeting). It should be put up to auction every five years, and sold to the highest bidder, who would bind himself to leave a reasonable head of game on the land, and to submit to arbitration the question of damages to crops from the keeping of an excessive head of game. It would, I think, be too radical a measure to make such a system compulsory at once, but I think local option might be given in this matter to parish councils. The good such a system would work in many parishes is incalculable. The result of the communal system abroad is that the casual poacher has ceased to exist. There is no 


\section{SMALL FREEHOLDERS}

chance for him where every peasant proprietor is an amateur gamekeeper, as this system makes him. Some years ago the writer had brought to his knowledge the case of a peasant in Germany who had shot a hare on a communal shooting. Although the rent received by this commune was only something like three pounds, which went into the parish funds, there was not the slightest sympathy shown with the poacher, who, by the way, was reported to the authorities by a neighbour. In suggesting a limit of a hundred acres, I should point out that it might be permissible for any landowner to hand over shooting in the parish to the council to any extent, and no doubt many would avail themselves of such a permissive clause. One hundred acres seems to me a good minimum, but on this point I am open to 


\section{SHOOTING-RIGHTS OF}

conviction. The money received may be applied to reduce the parish rate, but I suggest that it be paid to the freeholders direct, and, moreover, that the auction should be at per acre, purchaser to pay the cost of the distribution, advertising, etc., so that every cottager who has two acres would know, if the shooting let at a shilling, he would have to receive two shillings, free of any deduction whatever. He would have something, however little, tangible and honestly come by, to show for his right. This, if it went into parish funds, he might not realise.

Lastly, let us remember, if we are inclined to deal too tenderly with the small freeholder, that he is generally a representative of thieves or receivers. Either he is descended from those who in past days "squatted" on other people's land, 


\section{SMALL FREEHOLDERS}

or from those who bought it from such squatters. His right is good in law, but he never paid for it, like others, by "yeoman service in the wars," or in hard cash. 


\section{XXIII}

\section{DEAD WEIGHT}

F OR years the question of reducing the weight the sportsman, and especially the stalker, has to carry, has been one which I have been trying practically to solve. This is the result of my experiments :- $\mathrm{He}$ must carry in the pockets-handkerchief, knife (with cartridge extractor on it), money, shooting permit or licence, and, in my own case, spectacles. (A watch is only necessary to those who cannot judge the time roughly without, but it is indispensable in driving, 
when it should be compared with the head beater's, or with one lent to him.) On the belt, leather pouch holding ten cartridges and hunting-knife. In a small waterproof rucksack on the back, packet of ten cartridges, rifle-wiper, food (I recommend hard-boiled eggs, cheese, apples, and, of course, bread and salt), spirit flask (or, if in a waterless country, a bottle of cold tea). To these add, in a country where rain is possible, a thin waterproof cape; in a rocky country, a pair of jute-soled shoes for the actual stalk; in a strange country, a compass; if you smoke, your pipe, tobacco, and matches (the last always useful); if you contemplate sleeping out, a spare pair of socks. It is almost impossible that you can want all these together, but even if you do, you should not feel the weight thus disposed 
of ; and how often does one have a native, to whose shoulders the rucksack can be transferred? Over the right shoulder is slung the indispensable telescope; and over the other the rifle. This leaves the hands free for the alpenstock. I am going to come back to the question of weight directly, but here I just wish to refer shortly to the question of dress. Harris tweed, or cord coat, showerproof; flannel shirt, and woollen waistcoat (all wool, back as well), which can be transferred to the rucksack on a warm morning, are items nobody will quarrel with, but when one comes to leg-covering, everyone has different ideas. I, personally, swear by the kilt. One never gets too warm in a kilt, yet it keeps you warm on a cold day if you tuck it tight round your thighs; most of the rain runs off it, too, and it soon dries. 
At night (and every real sportsman has experience of nights in very rough quarters) take it off, lay it lengthwise over your legs, tuck in well, and you have a warm blanket. Moreover, it forms a soft dry seat, and there is a lot of sitting about, sometimes very hard, and sometimes disagreeably soft, in stalking. Last, but not least, it practically never wears out. But whether kilt or comfortable breeches, which do not chafe or strain you anywhere, are preferred, I equally recommend as a leg-covering a footless stocking coming down two or three inches outside the top edge of the boot. With this a pair of socks makes a change; if you wear a long stocking, you must carry the whole thing twice, or be without a change. Besides, you must wear anklets or some form of leggings, or else earth, small 
stones, or sticks will get into your boots, and you will have to be continually taking them off. The Indian putties, or bandages, are good, but take time to put on, and must be removed to get the boot off. Whatever sort of hat or cap you affect, for comfort it should have a brim fore and aft.

Now, where can we reduce the weight? In the telescope it has been lessened of late years by substituting aluminum for brass. Nothing more can be done here. In the rifle? For a long time I could not see how. Hollow the stock? No, because that must spoil the balance. Reduce the thickness of metal in the barrel? Not to be thought of, as the only result would be to unduly weaken the barrel. Shorten the barrel? Yes; here, perhaps, something might be done. 


\section{DEAD WEIGHT}

Thirty inches is what we may call a standard length of barrel, in England at anyrate, though most modern rifles are made a bit shorter, say twenty-eight or even twentyseven inches. If six or eight inches could be taken off this standard length without impairing general sporting efficiency, much would be gained, namely-Firstly, the rifle would be lightened by the actual weight of the metal removed; secondly, there would be a corresponding lightening of the stock in making the weapon balance; thirdly, half a dozen inches of useless metal sticking out when the rifle is slung for a climb up a thicket-covered hill, and catching every branch which the head is bobbed under, would be dispensed with; and, lastly, the effort of steadying the weapon in standing and snap-shots would be greatly reduced. 
At the time I made the experiments necessary to my purpose I was greatly handicapped in various ways. In the first place, I was abroad, and in a place where I could neither consult any printed or living authority on rifles. Secondly, though I had a fair amount of experience with them, I had no practical knowledge concerning the making or altering of these weapons. But, as Surtees tells us, there are two kinds of knowledge, the one the knowledge that a man has, and the other that which he knows where to get. This last I had; and accordingly wrote a series of questions to the sporting papers. Among those who replied to my queries were a well-known firm of gunmakers, who said that in their opinion the practical sporting efficiency of a rifle would not be impaired by making the barrel 


\section{DEAD WEIGHT}

twenty-four or even twenty-two inches only, but that the sights would be so near together that an orthoptic behind the hammers would be necessary. Another correspondent sent a table of velocities of different length barrels, from which I extract the following, roughly converting centimetres in the length of barrel into inches, and metres in the muzzle velocity into feet :-

Length of Barrel $\left\{\begin{array}{lllll}\text { Centimetres } & 80 & 70 & 60 & 50 \\ \text { Inches } & 31 & 27.5 & 23.6 & 19.6\end{array}\right.$

Muzzle Velocity in Feet

(Approximate-slightly under)

$2145 \quad 2105 \quad 2046 \quad 1996$ (Approximate-slightly over)

The first thing I noticed about this table was that the velocities throughout were very high - in fact, about those of the United States army weapon-and certainly obtained with a nitro-compound powder. A table of velocities in these lengths of barrel in an 
ordinary sporting rifle would have been much more use to me, but still I thought that proportionately these would be similar, and that therefore I might take it that if the loss of velocity between a barrel of thirtyone inches and one under twenty was under one hundred and fifty feet-say one-fourteenth, it might also be taken as hardly worthy of consideration in a sporting rifle. Now, although I laboured under certain disadvantages, as I have already explained, I also had a considerable advantage, which was that I had to my hand a weapon on which I was prepared to experiment. This was a .400 express rifle of American make but stocked to my measure in England. The barrel of this was thirty inches long and perfectly cylindrical outside from breech to muzzle. The foresight was one inch from 


\section{DEAD WEIGHT}

the muzzle, and the backsight seven inches from the breech. They were thus twentytwo inches apart.

Being in Greece at the time, I enlisted the services of a military armourer, and told him to cut eight inches off the muzzle end of the barrel. When this was done-and by the way very well done-I made him replace the sights, foresight as before one inch from the muzzle, backsight two and a half inches from the breech. They were consequently eighteen and a half inches apart, and the backsight was four and a half inches nearer the eye than before. I had given the armourer half a dozen cartridges, with which he reported that the altered rifle shot well; but subsequent experience showed me that if he had tried it at all it must have been at an absurdly short range. I found some 
difficulty in procuring a suitable range myself, but at last picked out a pretty good hundred yards, though across a gully.

I may remark that I had already found out that the altered weapon handled and balanced beautifully, which with the long, heavy barrel it had been very far from doing previously. The target used throughout the trials measured twelve inches by seven. This first day I began at a hundred yards, but only hit the mark once in six shots. On going to examine, I found the other five could be covered with the hand, but these were quite eighteen inches below the bull. It was obvious then that my solitary hit was a "bob." I finished the packet of cartriclges at sixty yards, and here again all four struck close together-all just below the target. This trial conclusively proved that the rifle 


\section{DEAD WEIGHT}

was undersighted, or in other words that the result of my having altered the relative positions of the sights to one another, or to the eye, involved a considerable increase in elevation. This, of course, I had not the technical knowledge to foresee. The only thing to be done was to have the sights altered, and for this purpose I adjourned the trials. I decided to have the backsight raised, which, of course, was the easiest thing to do; but if I had it to do again, and were in England at the time, I think I would rather have the foresight lowered, for the reason that the higher the sights the greater the error if the weapon is inadvertently held in the least degree crooked.

The original vertical height of the backsight above the barrels was exactly a quarter of an inch; the new one was .325 inch. 
Therefore there was a difference of .075 inch only between the two, which, however, proved ample.

Unfortunately, when I arrived at my "range," I found the proprietor had dug up the vineyard on which I had originally lain, and, worse still, given it such a slope downhill that I could not cover the target. All I could do was to make a heap of vineclippings, which abraded my elbows, and formed but an unsteady rest. Added to this there was a bright sun glinting on the sights ; and, to crown all, I was conscious of a distinct "personal error" in the shooting. However, with it all, I managed to put on fifty per cent. of hits on the little target, and few, if any, of the shots would have missed a small deer.

Being, however, one of those not to be 
satisfied with a doubtful result, I had another trial two days later on a fresh piece of ground. Of my first six shots at a hundred yards, five struck the small target, and of these four were within six inches. As this would be a satisfactory result with any rifle fired (by me) without a rest, I did not consider it necessary to continue the experiment.

The following week I took the rifle on an ibex-shooting expedition, in which I had certainly more hits than misses, nor can I lay the blame of the latter on my weapon. Since then I have used it successfully for chamois, etc., at distances up to 130 yards, and also at the target.

At the longer ranges the results have been less satisfactory, but this I am satisfied is due to the sights being so near together, 
It has never been in England since, but I have now sent for it in order to have an orthoptic fitted, which I am convinced is all that is required. If I am right, it is clear that a great opening has been made for sportsmen and gunmakers to reduce the weight of rifles, and consequently the stalker's burden. Especially will this be the case with high velocity weapons burning smokeless powder.

How many chances have been lost to sportsmen by the rifle being, at the moment when an unexpected chance occurred, in the hands of a native? And why? Simply because it was so heavy. I, personally, never part with my rifle, and am sure mine is the best plan; but those who think with me are all the more interested in the question, 
I do not contend that short-barrelled rifles would be equally effective at, say, five hundred yards range. But in my experience more big game is killed at under a hundred yards than over. Two hundred yards is all the sportsman wants. Disregarding telescopic sights and similar dodges, I find that, at over that distance, it is not possible to lay the rifle on the proper spot, because the "bead" covers too much of the animal. Experience shows me that my gunmaker correspondent is right: except at short ranges, a hundred yards and under, an orthoptic is necessary with a short barrel. But this is no objection. They ${ }^{1}$ are almost universally used by American sportsmen, and said to be quick and handy, even for running shots. At all events, I am not too

${ }^{1}$ Lyman's Patent. 
dogmatic to try them; and if they make my shooting with the 22 -inch barrel as certain at two hundred yards as it is now at a hundred, I shall be more than satisfied. 



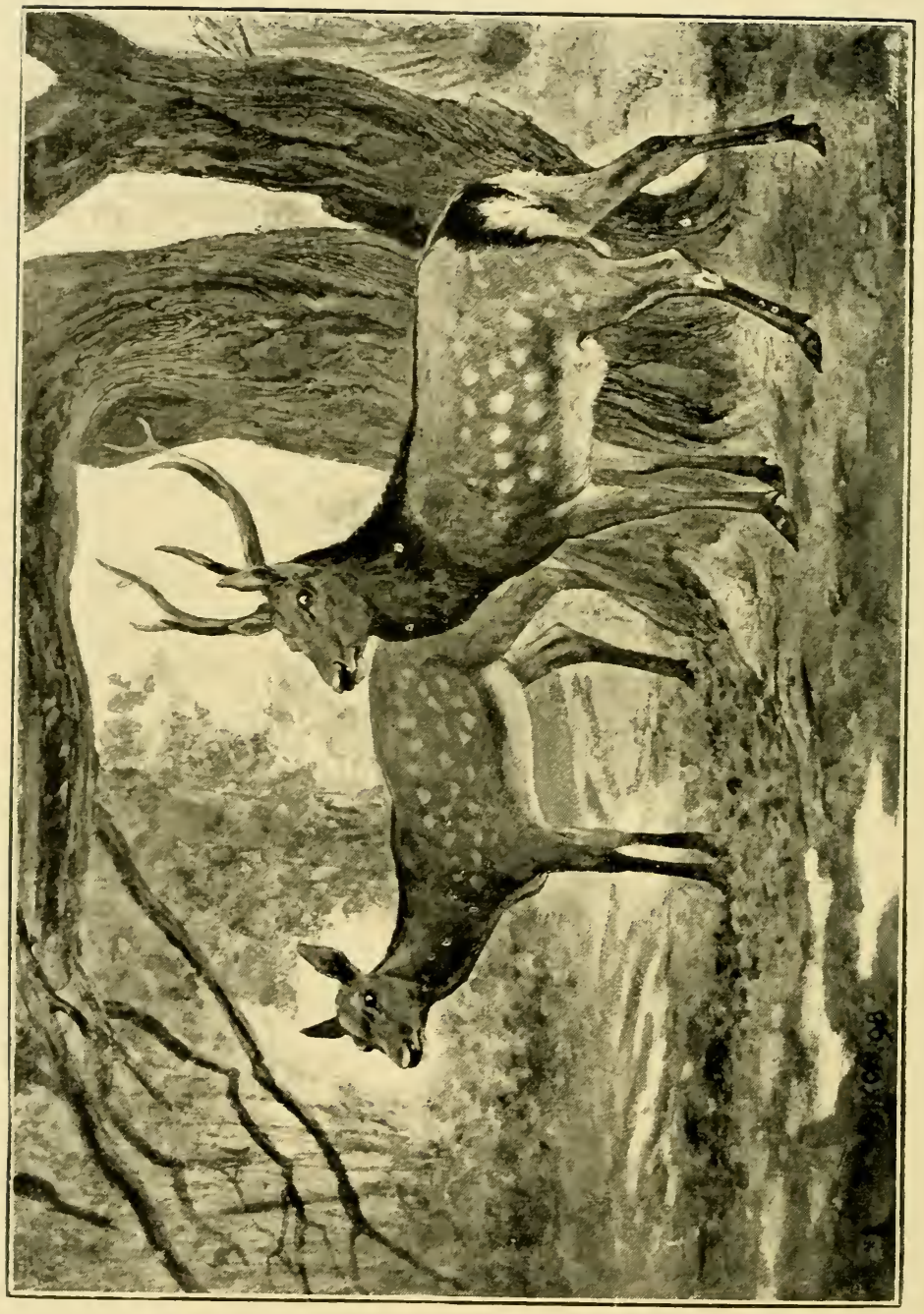

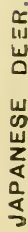




\section{XXIV}

\section{JAPANESE DEER}

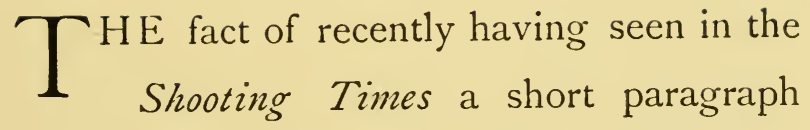
about that handsome little animal, the Japanese deer (Cerous Sica), has reminded me that this is an animal undeservedly neglected by British sportsmen, of whose attention it is, in my opinion, more worthy than the indigenous roe-deer, an animal, however, whose cause I am never tired of pleading. That the Japanese deer is eminently suited to acclimatisation in Great 
Britain has been triumphantly proved by Lord Powerscourt, who started at Powerscourt in 1860 with three does and a buck, and in 1884 had over a hundred, in addition to many which had been shot or given away. Writing under correction, I think the Shooting Times said that there were now no Japanese deer at Powerscourt, so that the herd must have recently been dispersed or sold. There is (or was when I was hunting with the Grafton a few years ago), however, a large herd at Whittlebury Park, Sir G. Loder's place near Towcester. But it is not as park deer that I wish to bring the animals to the notice of the English sportsmen.

The antlers of the Japanese deer have nominally eight points, viz., brow, tray, and two on top of each horn, but the anterior 


\section{JAPANESE DEER}

tine, or top, is considerably longer than the hinder one. In summer they are spotted with white, but the winter coat of the adult deer is dark brown, almost black. Lord Powerscourt writes: "The Japanese are a most satisfactory little deer; the venison, when dressed, is about the size of Welsh mutton, and very well flavoured. The little stags, with their black coats and thick necks, like miniature sambar, are very picturesque and ornamental, and I think they are a decided addition to our varieties of hardy park deer. Some of them are always to be seen in the Zoological Society's Gardens, but these give no idea of the beauty of the animals when in a wild state. They have also a most peculiar cry in the rutting season -a sort of whistle, varying sometimes into a scream." The Japanese deer has been 
300 JAPANESE DEER

almost, if not quite, exterminated on the larger island, but is pretty plentiful on the northern one. Unborn fawns are considered by the Japs an especial delicacy - a fact which accounts for such wanton destruction of does. They are also found in Northern China, and from the same country come the allied Manchurian deer, and Dybowski's deer. Another relative is the deer of Formosa; and lastly we have the Caspian deer, about which very little is yet known, which completes the group.

Japanese deer are always on sale at such places as Cross's and Jamrach's, but can probably be obtained cheaper by application to the head-keeper of such parks as they are kept in. The very qualities (i.e., their sticking to the woodlands) which cause them to give such poor sport in their națive countries 
make them invaluable to English shootingowners and tenants. Like the roe, they will rarely if ever stray beyond the covert, especially if a few bundles of hay are thrown down in the rides in very severe weather. Still, if possible, I would select a well-fenced covert with no root fields bordering it. They will, of course, do damage to young trees, but (alas!) timber is worth so little now in England, that this will be well compensated for by a close stalk on a late summer evening, or a day's driving later on. The best fun would be driving them to the gun with beagles, but this must only be practised on large estates, as the probable result will be a shift of quarters to the next covert; and for this reason a woodland where hounds often come should be avoided. A covert with open glades or with under- 


\section{JAPANESE DEER}

growth of different ages, of about a hundred acres and traversed by a brook, will be found the most suitable. Another reason for avoiding a hunting country, if possible, is that the foxes will have to be looked after pretty sharply at first. But if plenty of shot rabbits are left about, the fawns will be pretty safe.

I shall be much interested to hear of any sportsman's experience with either Japanese or roe-deer on these lines. 


\section{XXV \\ ROBERT S. SURTEES-AN APPRECIATION}

SEVEN or eight years ago a reviewer (who I venture to suppose was then but young at his work), having to notice a new edition of Handley Cross, contemptuously remarked that this class of work had had a certain vogue a score of years before, but might now be considered as quite out of date, so that the object of reprinting them was difficult to understand. This dictum caused quite a stir in the sporting 


\section{ROBERT S. SURTEES}

world. An old sportsman said to the writer, "They'll be saying the same of the Bible next"; and I believe the remark was made in all seriousness.

"Jorrocks" was, however, soon vindicated. From all parts of the kingdom, indeed I believe from all parts of the world, came letters to the editor which conclusively proved that the "vogue" of Surtees' works was perhaps greater than ever. I propose in the following article to inquire into the causes of that lasting popularity, although I am considerably handicapped by writing at a time and place at which I am unable to refer to any of the works in question.

One reason which might occur to the most casual observer is that, in those books which are most generally before the public, Surtees had the immense advantage of co-operating 


\section{AN APPRECIATION}

with no less an artist than John Leech. Indeed, it may be said that in some cases the letterpress was written up to the illustrations. In one edition of Handley Cross, not illustrated, and which I believe to be the original one, there are many variations from the wellknown text. For instance, the horse which declines to be led over on Mr. Jorrocks' first day is Xerxes, and here it is obvious the later text was altered to suit Leech's famous picture (perhaps the most famous of all), "Come hup, you hugly brute." Again, only a few lines of "diary" are devoted to the "Cat and Custard Pot Day," but it is not clear whether we really have to thank Leech's drawings for the existence of what is probably the very best account of an average run with foxhounds that was ever written. Certain it is that the five books to which Leech 20 


\section{ROBERT S. SURTEES}

furnished illustrations are far the best known of Surtees' works. Hawbuck Grange, which Browne ("Phiz") illustrated, though published in the same series, is far less well-known, but it is only just to say that it is probably the least amusing of Surtees' works. Not long ago I saw it appreciatively quoted by the late Lord Suffolk, who, like many another sporting writer, often and often made reference to Handley Cross and others of our author's books. Hillingdon Hall, which was republished some years back, is far less wellknown than it deserves to be. Jorrocks' Jaunts and Jollities, as far as I know, has never been illustrated, and a new edition is badly wanted. It is very unequally written, but parts of it are inimitably funny. The humour of the trip to Paris, at the commencement of which Jorrocks, wishing to "sink 


\section{AN APPRECIATION}

the shop," describes himself as "Chasseur," but ultimately signs the procès-verbal of his abortive duel as "John Jorrocks, Grocer (and Colonel in the Army when I'm in France)," will not be soon forgotten by those who have read it. The descriptions of sport with fox and stag in Surrey, again, are quite first-rate; but the accounts of the Cockney humours of Margate are really only interesting to the students of life in the early Victorian days. To some editions of this work a life of the author has been affixed, but it is a very jejune one, possibly for the reason that little or nothing was really known of the man--as distinguished from the writer. One fact of some importance, however, it does contain, and that is a statement that he never revealed the original from which he drew the portrait of the inimitable sporting grocer-indeed 


\section{OS ROBERT S. SURTEES}

denied that there was any prototype. If this is so, it cannot be denied that Surtees achieved that in which so many writers fail, and brought before his readers a living reality, and possibly a more vivid one than Thackeray ever drew, or even Dickens. Of Jorrocks it may be said that we know all about him, and can even foresee how he will act on any particular occasion. His honesty, hard-working habits, and thrift are blended most perfectly with his love of the bottle, devotion to hunting, and, it must be added, to the fair sex. In depicting his hero's knowledge of mankind Surtees fairly let himself go, and wrote what he himself felt, though he conceals it often under such semi-honest actions of old John's as sticking a horse into a friend at double the price he had just paid for him, or showing himself 


\section{AN APPRECIATION}

well experienced in such "tricks of the trade" as showing sugars on "witey-brown paper."

Surtees, probably more than any other writer, had the trick of interesting his reader in an anything but faultless hero. We all love Jorrocks, though we should probably be rather aghast to see him in our own houses. Sponge, rogue as he is, he wins our sympathies at last none the less, for throwing all his fortune-hunting schemes to the winds to marry the portionless girl of his choice. Romford again, whose manners and appearance would have been quite against his obtaining a groom's place in any decent household, gains our affections by his bold horsemanship and thorough sporting character, as evinced by his treatment of Mrs. Watkins' bagman, and we only wish we might have been by his side the day he 


\section{IO ROBERT S. SURTEES}

hunted Mr. Stanley Sterling's fox. In his later books (at least, I suppose them to be such), Ask Mamma, Plain or Ringlets, and Hawbuck Grange, there may really be said to be no hero, for nobody can take much interest in Fine Billy, Bunting, or even John Scott. In Hillngdon Hall we have an old friend, Jorrocks again, Jorrocks older if perhaps not much wiser, Jorrocks glorified, J.P., and at last even M.P. Underlying the light humour of this latter work is a purpose, however ; it is throughout the work of a country gentleman who foresees the ruin to agriculture the Repeal of the Corn Laws is to bring with it. It is also a scathing commentary on those townsmen who think they can teach farmers their business, but really all Surtees' books are more or less of the nature of a country gentleman's vade mecum. Take 


\section{AN APPRECIATION}

Ask Mamma, for instance, and see how much can be learnt on estate management from Sir Moses Mainchance and Major Yammerton. But in Hillingdon Hall Surtees may be said to give himself up almost entirely to this matter. Jorrocks, who seems to have learnt less about country life in his hunting days than most men, goes down to manage an estate he has bought, and although he lets his tenants see that he cannot distinguish an oat crop from wheat or barley, he lectures them on agriculture, till his career is at last checked by Pigg's telling him that they are practically adopting the most ridiculous ideas, such as making drain-pipes with sugar, with which Jorrocks (unknown to Pigg) has filled their heads. But the book contains much "brave fooling"; and the letter in which Jorrocks accepts a J.P.-ship, “I will not 


\section{I2 ROBERT S. SURTEES}

say nolo beakopari, etc.," is an instance that Surtees himself has probably never beaten.

My own reference to James Pigg reminds me of another character, who, both in Handley Cross and Hillingdon Hall, is almost as prominent as Jorrocks himself, and perhaps equally popular with sporting readers. The great point, however, of this conception of our author's is the admirable foil which the "Scotch huntsman" (as Mr. Jorrocks insists upon calling the Northumbrian) forms to his master. As a rider he is as bold as the grocer is timid; in fact, the only points they have in common are their love of hunting, drinking, and the sex. Pigg can perhaps hardly be spoken of as a regular huntsman, but he is the only one, with the exception of Jock Haggish, whom Surtees depicts as worth his salt. Which of 
us would care to have Dick Bragg, Findlater, Lotherington, Boggledike, or Swig in his service? Frostyface is perhaps better; but in the Flat Hat Hunt it is after all the Master and his double who seem to show the sport. Even Jock Haggish, though he can find and kill a fox, cannot ride to his hounds. Altogether, Surtees seems to appreciate professional huntsmen but little.

Another of the points which must strike a reader of these books is the author's contempt for the titled aristocracy. In none of them do we find a nobleman we should care to meet. The Duke of Donkeyton is an ass, the Duke of Tergiversation part fool and part rogue, Lord Ladythorne a vicious fool, the Marquis of Bray a fop, and Lord Scamperdale a miserly scarecrow. Nor dc the baronets fare better. Sir Moses Main- 


\section{I4 ROBERT S. SURTEES}

chance is a Jewish rogue, Sir Harry Scattercast a sot, Sir Archy Depecarde a leg, and so on. But if Surtees could not depict a gentleman with a title, who could better draw one when he wished-without-as witness Stanley Sterling of Rosemount, or Jovey Jessop of Appleton Hall. But it must be admitted a lady was beyond him. Belinda Jorrocks was perhaps the nearest he got, but she is quite colourless-a mere outline. His notion of women was that their one idea was to capture a husband, and in the book (Plain or Ringlets) that is most concerned with the adventures of one, we leave the heroine with no regret ; indeed, our author rather congratulates Bunting on having escaped the noose. It must be admitted that we should neither choose one of Surtees' noblemen for a friend, nor one of his women- 


\section{AN APPRECIATION}

kind for a wife. He shared both these failings with Thackeray; and as Thackeray unwillingly interested the reader in Becky and Beatrix when he meant us to like Amelia and Lady Castlewood, so it must be confessed does Surtees in Lucy Glitters, whom he himself describes as "tolerably virtuous." But he at least drew no paragons. “Did you see Nôtre Dame?” asks Nimrod of Jorrocks when they foregather at Calais after the trip to Paris. "No," is the hero's reply; "but I've seen some werry naughty dames all the same." But if we do meet some "naughty dames" in Surtees' pages, they will do us no harm. Even poor Lucy's shortcomings are touched upon with a very light hand. No boy or girl will be the worse for reading these books, and few of them will fail to appreciate. That is the charm of 


\section{I6 ROBERT S. SURTEES}

Surtees; everybody appreciates him. The writer has put his works into the hands of the most different people, young ladies with rather a prepossession against sport, London literary men with a positive dislike to country life, foreign naval officers in no sense sportsmen, and all have equally enjoyed them. This goes far to prove their reality ; the characters, if indifferent honest, must be real, and this is why there is so little "go" about Plain or Ringlets, although it contains far more about "Admiration Jack" than the lady whose locks it is supposed to turn on. But if his women are of little interest, his men are, as has been said above, real enough, and full of variety. Besides those already alluded to, who can forget Captain Doleful, Bill Bowker, the great O'Dicey, Jack Spraggon, Jawleyford, Squeaky Stotfold, and dozens of others, 


\section{AN APPRECIATION}

to some of whom pages are devoted, while others are sketched in with a few felicitous lines? Surtees sometimes repeated himself in incident, ${ }^{1}$ but never in a character. Each one stands apart. Sponge is a hard-riding, underbred, sporting rogue. Romford is a hard-riding, underbred, sporting rogue. But no two men could be more unlike than Romford and Sponge. Willy Watkins is a rich man, anxious to conceal his antecedents, and trying to ape the country gentleman. Marmaduke Muleygrubs is a rich man, anxious to conceal his antecedents, and trying to ape the country gentleman. Yet no individuals could in other respects

${ }^{1}$ E.g., that of the man who asks a bystander at a meet, "Have you seen my fellow?" and receives the answer, "No, I'm d-d if ever I did," which will be found in Handley Cross, in Mr. Romford's Hounds, and, as far as I remember, in Mr. Sponge's Sporting Tour. 


\section{3is ROBERT S. SURTEES}

present less resemblance to each other than Watkins and "Grubs," as Jorrocks calls him.

The epithet one sees oftenest applied to Surtees' works is "Rabelaisian." I do not think it is well applied. Surtees is sometimes coarse, and some of his coarseness does suggest Rabelais. On the whole, however, and not going by one or two carefully selected extracts from each book, I cannot admit the justness of the comparison. Even where coarse he is not Rabelaisian, for Rabelais had an object in his filth, which was to veil a hidden or esoteric meaning. Surtees is all on the surface, and he cannot be described anywhere as filthy. The fact is, that he is a writer sui generis; before him there were none like him, and since him there have but been imitations. If we want to know what the sporting writers of Surtees' own day 


\section{AN APPRECIATION}

were, we can turn to his own portrait of "Pomponius Ego"-not really a very highly coloured one. To that class of writer Surtees put an end.

Judging by the condition of his principal work, for such we must take the books relating to Jorrocks to be, sustained and continued effort was probably distastefui to Surtees. From the fragments of the Jaunts and Jollities we come to a continuous narrative lasting over some months (from the middle of one hunting season to the beginning of the next) in Handley Cross. But of his hero's doings during at least the latter half of this time we learn indirectly from the account of the two lawsuits which, at least the latter of them, are almost a blemish on an otherwise delightful book. The proceedings of the Lunacy Commission contain, it is 


\section{ROBERT S. SURTEES}

true, some bits we would not like to have lost, but they are almost buried in a heap of irrelevant and uninteresting matter. Finally, we leave Jorrocks beginning his second season with his hounds; and in Hillingdon Hall we find him some years older, and no longer a M.F.H. How many years we are not told, but Stobbs and Belinda are married and do not appear, and Pigg is reduced to cattle-droving. Benjamin, however, is still a boy, but it would appear that Surtees meant us to take Jorrocks as a good deal older. The fact is, that Surtees took no trouble to connect the two works. It is much to be regretted that he did not, and also weave the Jaunts and Jollities into a connected volume, forming as it were a Jorrocks Trilogy, instead of writing some of the later books, of which, for instance, Plain 
or Ringlets seems only to have been inspired by the wish to give Leech a chance to draw young ladies. Yet we would not willingly lose Jock Haggish, or Jovey Jessop and his Jug.

Some people look upon these books simply as caricatures; and so in some respects they may be, for it is hard to believe that Surtees wrote always of his contemporaries seriously: instance, the absurd and exaggerated way he dresses many of his characters. Nevertheless, they contain an undercurrent of what is by no means caricature. There is nothing impossible about Jorrocks, Pigg, Sponge, Leather, Jawleyford, or in fact the bulk of Surtees' characters. In Romford we admit there is exaggeration-not in the fact that such a man should be, but that an English county should receive him. The lesson the author meant to inculcate was obvious; in fact, 
322 ROBERT S. SURTEES

he gives it verbally - to point out what people will stand from a man merely because they suppose him to be "somebody" and rich.

We venture to think it is not as caricatures that these books live, but, on the contrary, because Surtees knew and described human nature; and that is the reason why when our modern reviewers wish to bestow their highest praise on a sporting novel, they say the author reminds them in places of the man who conceived John Jorrocks, grocer and master of fox-hounds. 


\section{XXVI \\ RACING IN CEYLON}

"I DO not know," writes a contributor in a recent number of Baily, "if racing is carried on anywhere in Ceylon or not." Now, as there may be a good many more people in the same state of blissful ignorance, I think it may be of interest if I note down a few memories of the turf in Ceylon: not, indeed, as it is, but as it was in the good old days of the seventies, when I played some little part thereon myself, premising that (as I believe) things remain very much in 


\section{RACING IN CEYLON}

the same condition, with the sole exception that those thick-and-thin supporters of the royal sport in the land of the spicy breezes, the planters, are now as prosperous on their everincreasing output of tea as they were then the reverse on a continually diminishing production of coffee. With improved finances, no doubt the quality of the racing has also improved, but not I daresay the good-fellowship of the old impecunious days, when we nearly all lived on advances, obtained with difficulty from the old Oriental Bank, who were then de facto the owners of pretty well every "shuck" coffee estate in the island. One has a feeling of regret, too, to think that the old concern failed to weather the storm, especially when one reflects that these same worn-out, worthless estates now grow the finest tea in the world. But this 
has nothing to do with racing, except as regards the very important part the greasy notes of the old bank played on settlingday. In spite of the bad times, racing went on as before, if the added money did decrease a bit and fields ruled smaller. In those days there were two regular meetings -that of the Colombo Turf Club and that at the Sanatorium, Newera Elliya. To these a third, at Kandy, was subsequently added, but it was not a great success. In addition to the regular meetings, there were an uncertain number of district and minor meetings, conducted in a more or less scratch manner-generally more, but sometimes, as at Blackwater, carefully and intelligently managed. The Metropolitan Meeting was, of course, the race meeting of the year. The Colombo Turf Club 


\section{RACING IN CEYLON}

provided four days' racing (sometimes five, if I remember rightly), but the "days" began when the sun got low (about 4 p.m.), and lasted till dark. Into this time four or five races were compressed.

In those days the horses were divided into "classes," and there was a complicated scale of "weight for age and class"- the idea being to bring together in one race, say an English three-year-old, an aged Waler, and a five-year-old Arab. Of course, this was a failure, and, practically speaking, each class raced by itself, as did the Galloways and the ponies. Any horse was "first-class" if not otherwise entered, and all second-class horses were liable to be claimed at auction for 1000 rupees (then nearly $£ 85$ ). The principal races were the Merchants' Cup (ist class), the Planters' 


\section{RACING IN CEYLON}

Cup (2nd class), and the Arab Derby. Perhaps the greatest betting race was the Champagne Stakes, a handicap T.Y.C. scurry, with selling allowances as low as $£ 25$. It brought out all the patched-up cripples in the place, but as it was nearly all on the turn, the result was generally, in such a big field, a fluke. There was also a hurdle race every day. Practically the betting was done by means of lotteries, and ran into biggish sums at times.

The racecourse at Colombo is nearly a perfect oval, just a mile round, and would not be a bad course if unfortunately the apex of the egg were not the home turn, the "straight" being about three furlongs. This sharp turn could not be banked, for a main road ran through it, and consequently the turn was a dangerous one. Of course, 


\section{RACING IN CEYLON}

the road was covered deep in sand, and would of itself have been no great drawback, except that its presence sometimes induced a bolt. The grand stand was the club-house, open at its upper storey to all the "airts that blow," and most convenient for seeing the racing, as there was not another tree or building on the course to intercept the view. All the Europeans congregated there, while the natives, in every description of vehicle and on foot, crowded on the ropes of the run-in. Among the supporters of the meeting from a distance were generally some Southern Indian stables, and for a number of years the late Maharajah of Johore. He had some good horses, but the only one of his I recollect was rather the reversePeter Simple. A cousin of mine originally 


\section{RACING IN CEYLON}

picked this animal up out of a batch for 400 or 500 rupees, and won several races with him, including a very sporting and heavy betting match. The Maharajah, or rather his agent, took him over at a long figure; but when they got him home, they found him so useless that he eventually found his way into harness. Among the local owners were John Baker, the sole remnant of the famous "Baker colony," who always had English horses; Beauchamp Duwnall, Johnstone of Annandale, Arthur Mercer, whose classically named Protos often acted up to his name; and, in later days, Dumaresq Thomas, the Farquharsons, Murray Robertson, Captain Mills, and many others. The professional jockeys of those days were Tingey, Mitchell, Ryder, Donaldson, and others whose names 


\section{RACING IN CEYLON}

I forget; but, as a rule, they were better trainers than race-riders. The amateurs were, of course, more conspicuous by their number than by their capability, but I remember one who made a great impression on me by winning a desperate race with his whip. I think he was on a chestnut gelding called Brushwood. I was, with other better judges, standing in the enclosure between the stand and the judge's box, and we all remarked how, every time the whip descended, the horse was exactly in such a position that it could not "knock him all abroad," and, as a matter of fact, it was the animal's response to three or four of these scientifically applied cuts, in combination with perfect "riding" with the left hand, that obtained a neck victory. Such a display of horsemanship I have never since 


\section{RACING IN CEYLON}

seen on the part of any amateur; and, if I may say it with bated breath, I have often thought that there are not a few of our professionals who would be better without the "flail" when it comes to a ding-dong finish. The youngster in question, whose name was Duncan, had learnt his riding in Australia, to which island he soon afterwards permanently returned. It would be interesting to know if he has since made his mark there.

Strange to say, the Arab Derby, which was a weight-for-age race, two or two and a half miles, never attracted the interest which, from our proximity to Bombay, might have been expected. Three or four was an average field. On one occasion I remember there was a strong competition between the Ceylon cracks and three horses 
sent down by the I 4 th Hussars from Secunderabad. I forget which of the lot they backed, but I distinctly remember one they did not-a very big iron-grey maiden called Tarlan. I fancy he was only put in to make a pace, but the result was that this horse was ridden by a "gentleman of colour," jumped away with a good start, and led the field such a dance that they never got within a dozen lengths of him, and he won very hard held. I recollect that, liking the animal's looks at exercise, I had bought his chance in a lottery for a trifle, so I was better satisfied than the stable, or indeed the jockey, whose fee on this occasion was paid with an ash-plant. Strange to say, next time I saw the horse he was waltzing on his hind-legs in Wilson's circus, which reminds me that that sportsman had a cut at us one 


\section{RACING IN CEYLON}

year he happened to be performing at Colombo. He ran two or three horses, but they were in no condition, and though a trick jumping-horse, called Bob, was rather fancied for a hurdle race, he failed to earn his brackets.

For most of us small fry, however, the principal interest of the meeting centred in the Planters' Cup, a mile weight-for-age race for maiden second-class horses. At first it was practically confined to those picked on their looks out of the "batches" that came up from Western Australia by sailing-ship, and was consequently full of interest; but later on it was rather spoiled by different syndicates importing a horse with a character on purpose for the race. I never owned or rode the winner, though it was won very easily by my old horse, Evenlight, before 
I bought him. This chestnut was one of the biggest thoroughbreds (he was by Oliver Twist out of a Kelpie mare) I ever saw, and on his first appearance he won seven races (flat and hurdle) out of eight starts, only being stopped out of the Forced Handicap at the end of the meeting by something like thirteen stone being put on his back. Unfortunately, like many another good horse in Ceylon, he was attacked by what is known there as "a stroke of the wind," which is, in fact, an incurable paralysis of some of the lumbar muscles. His hurdling days were over, but even with this affliction he could always do his mile in two minutes untrained. His end was curious. I left him behind with a brother officer to sell when I came home, and he went into native hands, only to reappear when some planter 


\section{RACING IN CEYLON}

(in all innocence, I believe) swept the board with him as a maiden at some up-country meeting! Strange to say, he was not recognised, and it was only when he again appeared at another Sky-races, that someone objected to him for not carrying his cumulative penalties on being entered as "late Evenlight."

One Planters' Cup is vividly impressed on my memory. A planter, whom I will call H. T., had a mare which he fancied could gallop, and asked permission to send her down to me to train and ride. I even forget her name, but I remember a nicer-tempered beast I never had through my hands. T. backed the mare heavily, whilst I did not, for I never thought her so good as he did. Then he got over-anxious, and asked if I objected to her being put in a professional's 


\section{RACING IN CEYLON}

hands to wind up her training. Of course I said no; but, in my opinion, she got too much fast work the last week, and came to the post with her ears back-a thing I had never seen before in her. The race that year was reduced to a match, so the start presented no difficulty, but as I rose in my stirrups to the mare's first stride, "heaven and earth suddenly came apart," and the result of this, my first experience of an Australian buck-jump, landed me "sejant" in front of my mount. As I had retained hold of the reins, I had a leg up before the stars had ceased whirling before my eyes, and saved my distance; but $\mathrm{T}$. would not object, although there was little doubt the second flag, if indeed the first, was not down when I "dismounted." The only injury was to my amour propre, especially as I recollect there 
was a fair being in the stand arrayed in my colours (sky-blue and pale pink); but, looking back a score of years at the occurrence, I don't think anyone could have been blamed - in a two-pound saddle, too! I have sat three honest running-bucks in a hunting saddle since then, but, strong as I was in the saddle as a youngster, I think, if there had been a fourth, I or the girths must have gone. That settling-day broke poor T., who had "gone for the gloves" over the race.

I don't recollect that my good friend G. C. (I mustn't mention his name, for he very likely is Merchants' Representative in Council now) ever won this race for the dangerous syndicate he trained for. I recollect his having a horse, satirically christened "Deerfoot," but known to us all as "Soup-plates," 


\section{$33^{8}$ RACING IN CEYLON}

from the enormous size of his feet. $\mathrm{He}$ had tried the animal good enough to win a weight-for-class race, in which D. W. H. Skrine (a pillar of the Ceylon turf I forgot to mention) had a thoroughbred (English, I fancy) engaged. The two met at morning exercise one day, and their talk turned on these races.

"All bosh," said Skrine. "What weight, I ask you, could bring a horse like this and one like that together?"

C. agreed. In the race he rode the stable pace-maker, and finished in the ruck in a most unorthodox manner, waving his cap and yelling, "Go it, Soup-plates!" As they returned to the paddock, he addressed the discomfited Skrine-

"Now, I ask you, what weight could bring a horse like that, and one like Soup-plates, 


\section{RACING IN CEYLON}

together?" - Deerfoot, needless to say, having won in a common canter.

But I must not suppose that all our little coups and mystifications will interest the reader. The Galloway races (I4 hands and under) were inferior in interest to the pony races (I 3.2 limit). For some time my old Indian pony, Fuzee, who came from the 12 th Lancers, ruled the roast in the latter class; but his nose was put completely out of joint by specially imported Australians, and subsequently English ponies.

The finale of the Colombo meeting was always a so-called "Arab race," in which the competitors were really Cabulee horsedealers. This race, barebacked, was run in heats, and the "legs and wings" finishings of the riders were indeed a sight. To this succeeded a three-furlongs race for native 


\section{0 RACING IN CEYLON}

trotting bullocks in harness. The band played "God Save the Queen," and we had thirty-six hours to make up our books, and, some of us, to raise the wind before Monday.

The Newera Elliya meeting was held in the hot season, when the Governor-General and other swells had left us to stew down in the plains. It was, however, a colourless reproduction of the previous August's Colombo performance, as new horses were invariably reserved for the heavier stakes and lotteries then. The other meetings were in a descending scale, ending with some district sky meetings, where the best part of the course was cart-road, i.e., unmetalled estate road, with ruts perhaps six inches deep. One year they got up a steeplechase meeting at Colombo. I was away, but heard after- 


\section{RACING IN CEYLON 341}

wards that it was a complete farce, not a single horse clearing the water-jump, and the winner finishing alone in the big race. Be this as it may, the steeplechases never were repeated. 


\section{XXVII}

\section{THE END}

THE first of February was fine and 1 bright with us-quite a summer day.

It happened to be a busy one with me, too, and I had no chance to empty my gun. In fact, it was not till afternoon tea time that it occurred to me it was the very last chance in the ' $97-98$ season to kill a cock pheasant. The hens (birds being none too plentiful with me) had been sacred for some weeks.

Tea being over, then, I went and got 
down the 20-bore, not forgetting first to light my pipe, and sallied forth-to the astonishment of my better half at the unorthodox hour-with a couple of dachshunds at my heels. Where to try? It must obviously not be too far. The shrubbery behind the orangery is generally good for a bird, but it is overhung with trees, and apt to become dark early. Not a hundred yards from the house is a long gorsy field of about a score of acres, surrounded by high wood. The edge of those woodlands should do. So I put my best foot foremost, and reach the top edge of this field soon after five-quite light enough to shoot. A hundred yards on, the dog begins to feather on the grass between two thorny patches of dry bracken. Query, rabbits? Both are busy now, but silent. 
See the bitch sniffing up on that pointed stone. It is not rabbits. I walk quietly on, close to the eager dogs. Something runs behind that bramble bush-and rises. I suppose I was (the old fault!) a bit under him with the right barrel, but as he tops the hedge, the full-choke doubles him up at fifty yards or thereabouts. Just as I "break" my gun, a second cock rises from behind a bush to my right, but I am not ready in time. So there is nothing to do but to walk on to my mark. As I peer over the hedge, I look right down upon my quarry, in the little bitch's mouth. What a picture! The bird is very nearly as big as the dog, but she holds him (albeit tenderly) for fear he may develop running powers. Jumping over, I take him from her, but, having no other means, must fain carry 


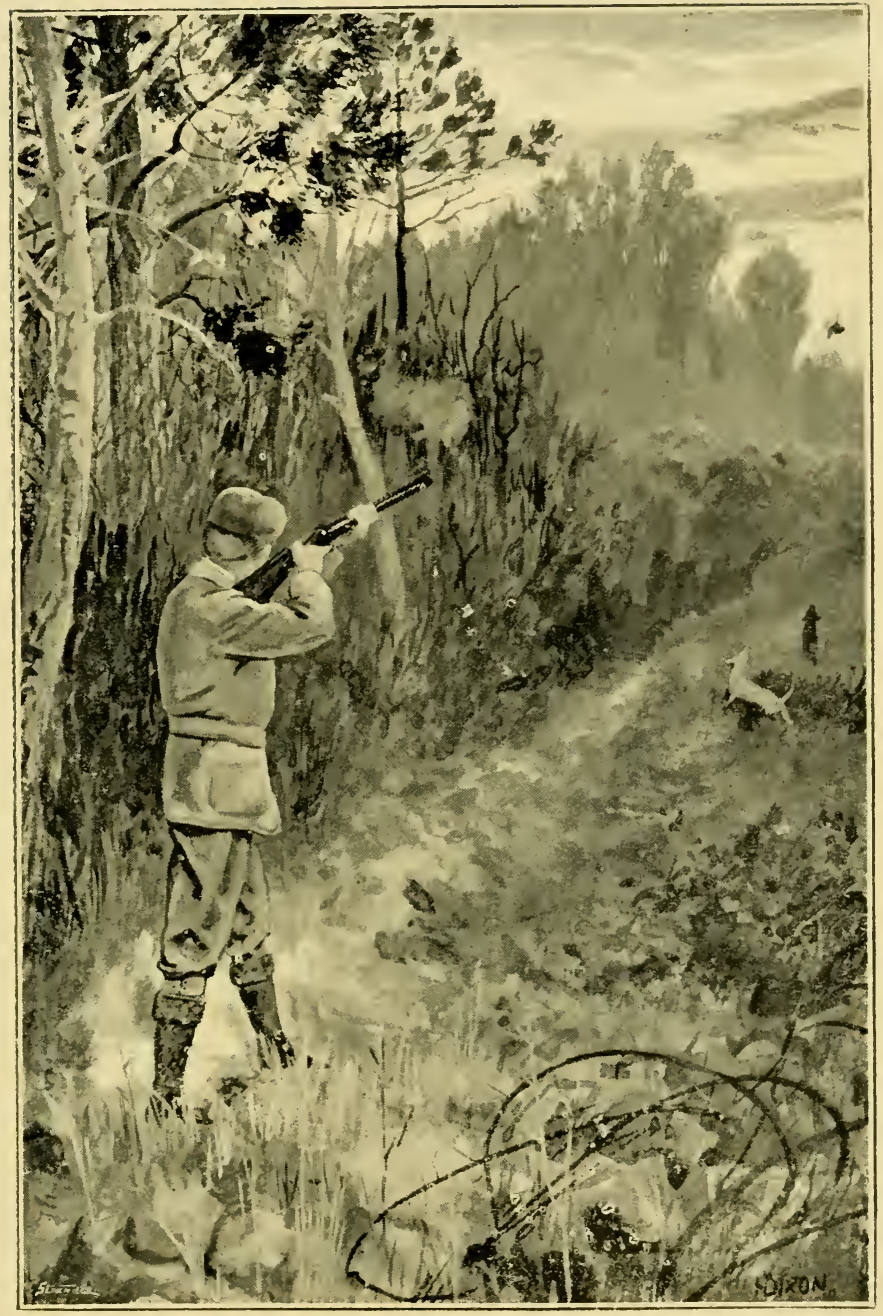

THE FULL-CHOKE COUBLES HIM UP. 
him in my hand. A two-year-old cock, in magnificent plumage, and turning the scale at three pounds and a quarter-very good for a ring-neck.

At the end of this field is a brake of some score years' growth, and in a minute the dogs find. But this time it is a rabbit, and loud-mouthed they go straight down to the old breeding earth. This does not interest me, so I walk on, and enter another lot of fields below. Not far on a cock partridge is calling loudly, but ceases as he becomes aware of the panting dogs rejoining me. As I go, a cock pheasant rises with a tremendous fuss in an adjoining field, whereas the other two had got up quietly, almost like hens. As I come to the gate by the brook, something runs up the field and then rises - $\mathrm{a}$ hen pheasant. But 
346 THE END

I walk steadily on, and before I reach the shrubbery gate the owl hoots loudly in the copper beech. So for seven months for all of us, and for ever for some, it is ThE END. 
No. LXXVIII.

\section{vol. Tbacker \& Co.,}

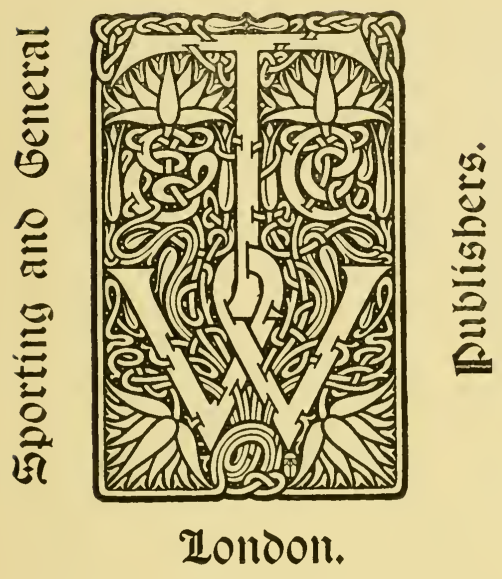

\section{CATALOGUE OF PUBLICATIONS $1898=1899$.}

Publishing and Editorial Offices of Phil May's Illustrated Annual. FOUNDED I 892 . 


\section{LIST OF AUTHORS.}

G. J. Whyte-Melville.

RUDYARD KIPLING.

CAPT. M. H. HAYES, F.R.C.V.S.

L. G. Carr laughton.

Capt. L. J. Shadwell, P.S.C.

HENRY O'BRIEN.

M. MOOKERJEE.

Vero Shaw.

JOHN WATSON.

FRED T. JANE.

Vety.-Major J. A. Nunn.

E. H. Aitken.

LiNCOLN SPRINGFIELD.

HAMLIN GARLAND.

D. C. BOULGER.

W. LAIRD Clowes.

H. G. KEENE, C.I.E.

Paul Cushing.

General KinLOCH.

Major W. Yeldham.

H. E. Busteed, C.I.E.

Alfred E. Pease, M.P.

H. S. THOMAS, F.L.S.

Lady Violet Greville.

Mrs. O'Donoghue.

Col. H. M. S. BRUNKER.

CAPT. F. E. S. Adair.

THACKER'S INDUSTRIES OF INDIA.

, INDIAN DIREctory.

" MaP OF INDIA. 


\author{
No. LXXVIII. \\ CATALOGUE \\ NEW AND RECENT \\ PUBLIGATIONS \\ ISSUED BY \\ W. THACKER \& CO. \\ 2, CREED LANE, LONDON, E.C. \\ AND \\ THACKER, SPINK \& CO. \\ CALCUTTA AND SIMLA. \\ ESTABLISHED 1819.
}


An Edition de Luxe of the Works of the late

\section{Major G. J. Whyte=Melville.}

EDITED BY

The Rt. Hon. SIR HERBERT MAXWELL, Bart, M.P. Demy 8vo., Gilt Tops.

Price 10s. 6d. net each Volume. The volumes are printed from new type on hand-made paper, specially manufactured for this edition, and handsomely bound in buckram with gilt tops.

With Coloured Frontispiece and other Illustrations by Hugh Thomson, C. E. Brock, G. H. Jalland, Edivard CaldDivell, Harrington Bird, AND OTHER WELL-KNOWN ARTISTS.

RIDING RECOLLECTIONS.

Approximate dates of Publication.

1898.

KATERFELTO.

Nov.

UNCLE JOHN.

Dec.

MARKET HARBOROUGH.

1899.

JAN.

CONTRABAND.

FEB.

M. OR N.

MAR.

TILBURY NO=GO.

APR IL.

BONES AND I.

MAY.

BLACK, BUT COMELY.

JunE.

THE BROOKS OF BRIDLEMERE.

SePT.

THE WHITE ROSE.

Ост.

ROY'S WIFE.

Nov.

SATANELLA.

DEC.

To be followed by the other works of WHYTE-MIELIILLE until completed. 
Super-Royal 8vo., Cloth; Gilt Top, 34/-

\section{Points of the Horse.}

\section{A familiar Treatise on Equine Conformation.}

BY

\section{Capt. M. HORACE HAYES, F.R.C.V.S. SECOND EDITION. Revised and enlarged.}

This Edition has been thoroughly revised and contains numerous additions, including specially written Chapters on the Breeds of English and Foreign Horses.

Illustrated by 200 reproductions of Photographs of Typical "Points" and Horses, and 205 Drawings by J. H. Oswald BRown.

"A year or two ago we had to speak in terms of praise of the first edition of this book, and we welcome the second and more complete issue. The first edition was out of print in six months, but, instead of reprinting it, Capt. Hayes thought it better to wait until he had enough material in hand to enable him to make to the second edition those additions and improvements he had proposed to himself to add. The result is in every way satisfactory, and in this handsome book the searcher after sound information on the make and shape of the horse will find what will be of the utmost use to him. Those who have been, or who contemplate being at no distant date, in the position of judges at horse shows, will derive great benefit from a careful perusal of Capt. Hayes' pages." -Field.

Thick Grown 8vo., Buckram, 15/-

\section{Veterinary Notes}

\section{for Horse $=$ Owners.}

\section{An Illustrated Manual of Horse Medicine and Surgery, written in simple language, with over 200 Illustrations.}

BY

\section{Capt. M. HORACE HAYES, F.R.C.V.S.}

\section{FIFTH EDITION.}

Revised throughout, considerably enlarged, and incorporates the substance of the Author's "Soundness and Age of Horses."

"Of the many popular veterinary books which have come under our notice, this is certainly one of the most scientific and reliable. If some painstaking student would give us works of equal merit to this on the diseases of the other domestic animals, we should possess a very complete veterinary library in a very small compass."-Field. 
Imperial 16mo., Buckram, 21s.

\title{
Illustrated Horsebreaking.
}

BY

\author{
Capt. M. HORACE HAYES, F.R.C.V.S. \\ SECOND EDITION.
}

This Edition has been entirely re-written; the amount of the letterpress more than doubled, and 5 reproductions of Photographs have been added.

"It is a characteristic of all Capt. Hayes' books on horses that they are eminently practical, and the present one is no exception to the rule. A work which is entitled to high praise as being far and away the best reasoned-out one on breaking under a new system we have seen."-Field.

Demy 8vo., 126 Net.

\section{Infective Diseases of Animals.}

Being Part I. of the Translation of Friedberger and Frohner's Pathology of the Domestic Animals.

Translated and Edited by Capt. M. H. HAYES, F.R.C.V.S. Author of "Points of the Horse," etc.

With a Chapter on Bacteriology by Dr. G. NEIVMAN, D.P.H.

"Our veterinary literature has certainly received a very valuable addition."Army and Nary Gazette.

"This is a work which no veterinary practitioner who is anxious to be thoroughly up-to-date in his professional knowledge can afford to be without." - Glasgow Herald.

Square 8vo., Cloth Gilt, 10/6.

\section{The Horsewoman. \\ A Practical Guide to Side-Saddle Riding. $\mathrm{BY}$}

\section{Mrs. HAYES. Edited by Capt. M. H. HAYES.}

With 4 Collotypes from Instantaneous Photographs, and 48 Drawings after Photographs, by J. H. Oswald Brown.

"This is the first occasion on which a practical horseman and a practical horsewoman have collaborated in bringing out a book on riding for ladies. The result is in every way satisfactory, and, no matter how well a lady may ride, she will gain much valuable information from a perusal of 'The Horsewoman.' The book is happily free rom self-laudatory passages."-Field. 
Crown 8vo., Gloth, Gilt Top, 6/-

\title{
Hunting Reminiscences
}

\author{
BY
}

ALFRED E. PEASE, M.P.

Author of "The Cleveland Hounds as a Trencher-fed Pack,"

"Horse-breeding for Farmers," etc.

Vith Illustrations by the late Sir Frank Lockivood, Cuthbert

Bradley, Heyivood HaRdy, AND From Photographs.

Contents.-The Cambridge Drag and House of Commons Steeplechase. The Life of a Hunter. Hounds. Hare-Hunting. Fox-Hunting. Badger-Hunting. Cub-Hunting. The Greatest Run I ever saw, etc.

Also an Edition de Luxe, limited to 200 numbered copies at one guinea net, beautifully printed from newly-cast type on Dickinson's hand-made deckled-edge paper, and the Illustrations printed on the finest art plate paper. In addition to this the size of the book is enlarged to demy 8vo., giving wider margins to the pages, and there are several extra Illustrations not included in the smaller edition.

"There is more to be learned rom Mr. Alfred E. Pease's little volume of 'Hunting Reminiscences' than from a library of more pretentious treatises. The frontispiece is a portrait of the author himself on a favourite mare. But where he really paints himself is in every page, and long before we have got to the concluding chapter we seem to know him intimately as we like him much. Mr. Pease, like Sol Gills, is 'chockful of science,' but there is not a touch of pedantry in his manner of imparting his knowledge-the reader picks it up incidentally as he goes galloping along, for the pace is good from the start to the finish."-Times.

Imperial 16mo., $10 / 6$.

\section{Riding for Ladies. With Hints on the Stable.}

BY

\section{MrS. POWER O'DONOGHUE.}

With 9i Illustrations by A. Chantrey Corbould.

"It is characteristic of her book, as of all books of any value, that it has a distinctive character. Sound common sense and a thoroughly practical way of communicating instruction are its leading traits."-Daily News.

Crown 8vo., Cloth, 6/-

\section{Ladies in the Field. Sketches of Sport. \\ Edited by the LADY VIOLET GREVILLE.}

Contents.-Riding in Ireland and India, by Lady Greville. Hunting in the Shires. Horses and their Riders, by the Duchess of Newcastle. The Wife of the M.F.H., by Mrs. Chaworth Musters. Fox Hunting. Team and Tandem Driving, by Miss Rosie Anstruther Thomson. Tigers I have shot, by Mrs. C. Martelli. Rifle Shooting, by Miss Leale. Deer Stalking and Deer Driving, by Diane Chasseresse. Covert Shooting, by Lady Boynton. A Kangaroo Hunt, by Mrs. Jenkins. Cycling, by Mrs. E. R. Pennell. Punting, by Miss Sybil Salaman. 
Demy 4to., handsomely bound, 42/-

\section{Large Game Shooting}

IN

\section{Thibet, The Himalayas, and Northern India. BY}

\section{Brigadier-General ALEXANDER A. KINLOCH.}

Containing Descriptions of the Country and of the rarious Animals to be found, together with Extracts from a Fournal of several years' standing.

Third Edition, with 34 beautiful Illustrations and a Map of the District.

"The splendidly illustrated record of sport. The photogravures, especially the heads of the various antelopes, are lifelike; and the letterpress is very pleasant reading."-Graphic.

Large Crown 8vo., 10/6.

\section{A Book for the Sportsman and Traveller. The Snaffle Papers. \\ BY}

" SNAFFLE,"

Author of "Gun, Rifle, and Hound," "In the Land of the Bora," "In the Fungle," etc.

Illustrated by HARRY DIXON.

Crown 8vo. Sewed, 1/6.

\section{How to choose a Dog and How to select a Puppy.}

With Notes on the Peculiarities and Characteristics of each Breed. BY

\section{VERO SHAW.}

\section{(Author of "The Illustrated Book of the Dog." Late Fennel Editor of the "Field.")}

"Each breed of dog has a chapter to itself which opens with a few introductory remarks of a general nature; then follow the points briefly and plainly; next come average of the pup from six weeks old until he attains maturity. A couple of pages at the end of the work are devoted to the relation, and a few useful hints on buying, feeding, and breeding. Needless to add that like all Mr. Vero Shaw's writings on canine subjects the information is founded on practical experience and imparted in easy excellent English."-The Stock Keeper. 
Medium 8vo., 2/6.

\section{The Best Breeds of British Stock.}

A Practical Guide for Farmers and Owners of Live Stock in England and the Colonies.

BY

\section{J. P. SHELDON and JAMES LONG.}

\section{Edited by JOHN WATSON, F.L.S.}

"A useful guide for farmers and owners in England and the Colonies by wellknown writers. These specialists treat of each variety of horses, cattle, sheep, and pigs in readable and, at the same time, essentially helpful papers."-Daily Telegraph.

F'cap 8vo., Gloth, 6/-

\section{The Sportsman's Manual.}

In Quest of Game in Kullu, Lahoul, and Ladak, to the Tso Morari Lake.

BY

Lieut.=Col. R. H. TYACKE.

(Late Her Majesty's 98th and 34th Regiments.)

With Notes on Shooting in Spiti, Bara Bagahal, Chamba, and Kashmir, and a detailed description of Sport in more than 100 Nalas. With 9 Maps.

Oblong Folio, Cloth Gilt, 10/6.

The Latest Addition to Naval Literature.

A New and Important Work on Torpedoes.

\section{The Torpedo in Peace and War. BY}

\section{FRED T. JANE,}

Author of "Blake of the 'Rattlesnake," "All the World's Fighting Ships," Inventor of the Fane Naval War Game, etc.

With about 30 full page and a great many smaller Illustrations, the greater part of which are reproductions of Sketches made at Sea on board Tol pedo Craft by the Author. 
Cloth, 16 mo., 5s. net.

THIRD YEAR OF ISSUE.

\title{
Clowes' Naval Pocket Book, 1898.
}

\section{Founded by W. LAIRD CLOWES.}

(Fellow of King's College, London; Hon. Member of the Royal United Service Institution; Life Member and Gold Medallist of the United States Nival Institute.)

Edited by L. G. CARR LAUGHTON.

The most valuable work of reference now available, containing a full list of Battleships, Ironclads, Gunboats, Cruisers, Torpedo Boats, a list of Dry Docks, and other valuable information, concerning $A L L$ THE NAVIES OF THE WORLD. Corrected to February, 1898.

\section{Lord Charles Beresford says:-}

"It is one of the most useful and handy works of reference on naval matters that I know of, and invaluable to all who take an interest in naval matters."

"This valuable, concise, and well-packed book gives its matter in a orm considerably improved from that of the original issue last year; and the editor of the work, Mr. WV. Laird Clowes, is to be congratulated upon the skill with which he has brought the many figures and facts in the book up to date. The arrangement of the matter for purposes of reference is admirable, and the 'Pocket Book' cannot but continue to grow in the estimation of those for whom it is designed." - Scotsman.

Founded in the first instance by Mr. Laird Clowes, the present issue is edited by Mr. Carr Laughton. The information contained upon the navies of the world is most complete and comprehensive, and the 900 pages of printed matter are remarkable for containing so much in so small a compass. To give some idea of the completeness of this volume, we will refer to the little principality of Sarawal with its three vessels, and the Republic of San Salvador, which seems to possess only one.-Pall Mall Gazette.

Demy 8vo., 16s.

THE NEWEST WORK ON THE CONGO.

\section{The Congo State;}

Or, the Growth of Civilization in Central Africa. $\mathrm{BY}$

\author{
DEMETRIUS C. BOULGER. \\ Author of "History of China," "Chinese Gordon."
}

VITH 6 o ILlustrations.

Mr. Boulger's new book throws much light on the disputed territory.

Sir Charles Dilke, in the Saturday Review, says: "Over and over again he (MIr. Boulger) tells (and he would not have done so without the leave of the King of the Belgians, for this book comes near being an official volume) that the King of the Belgians will once more offer to take over the Bahr-el-Ghazl Territory, which was included in the Rosebery-Kimberley Lease."

"The style of the book is excellent."-Athenaum. 
Two Vols., Demy 8vo., 24/-

\title{
The History of China.
}

BY

\section{C. BOULGER.}

Author of "Chinese Gordon," "Sir Stamford Raffles," etc., etc.

A New Edition Revised and bRought Up-TO-DAtF.

With the Recent Concessions to the European Powers.

Illustrated with Portraits and Maps.

\section{A Cycle of Cathay.}

"The writer of Chinese history has no need to hunt for material. The records of a nation which has existed for close on 5,000 years should not be deficient in incident, and in the case of the Middle Kingdom a continuous series of revolutions, wars, and local disturbances affords a wealth of matter for the pen of the chronicler. The history of China is a subject which Mr. Boulger has made his own, and the present volumes are but the pendant to those which have gone before. The first edition of the work under review appeared many years ago, and despite the long intervals which ensued between the publication of the three volumes, and the high price at which they were issued, it attracted much attention among Orientalists, and was at once accorded the position of standard treatise on its subject. The present edition, in two volumes and at a reasonable price, has been carefully revised, and in addition contains close on a hundred pages dealing with recent events in China, which are chronicl:d up to the occupation of Wei-hai-wei, and thus supplies a complete epitome of Chinese affairs up to the present time. Regarded as a history pure and simple, indeed, Mr. Boulger's latest effort is all that such a work should be, and if some chapters in the romance of the semi-mythical period of the subject are omitted, or when included are only touched on lightly, the very full accounts given of the more important events may be taken as a full equivalent. In this respect our author is to be congratulated on having very nicely gauged the duties of the historian; and the compression of unimportant details, with the corresponding enlargement of particulars concerning matters of import, bears testimony to the sound judgment of the writer."-Pall Mall Gazette.

Demy 8vo., Gloth, 12/-

\section{The Cave Dwellers of Southern Tunisia.}

Recollections of a Sojourn with the Khalifa of Matmata.

Translated from the Danish of D.miel Brunn.

BY

\author{
L. E. A. B.
}

With Numerous Illustrations. 


\section{Lockhart's Advance BY \\ through Tirah.}

Capt. L. J. SHADWELL, P.S.C. (Suffolk Regiment).

Special Correspondent of " 7 he Fioneer" and London "Daily Neww."

With two Maps and seven full=page Illustrations from Photographs taken on the spot.

"And his plain, straightforward narrative makes the whole absolutely clear, from Peshawar right round to Swaikot; the exact situation at Dargai, the side excursions among the Chamkannis or to the Waran Valley, the reconnaisance to Dwatoi, and all-as clear as the excellent map which is appended. It may be unreservedly recommended to soldier and civilian alike."-Pall Mall Gazette.

Demy 8vo, Gilt Top, $12 / 6$ Net.

Third Edition of O'Brien's Round Towers of Ireland. Limited to 750 numbered copies.

\section{The Round Towers of Ireland,} Or the History of the Tuath=de=Danaans for the first time unveiled. BY

\section{HENRY O'BRIEN, B.A.}

With all the original Illustrations, to whach is added a portrait of the Author, reproduced from Maclise's zell-known drawing.

This new edition contains all that is to be found in the previous editions, including the curious preface, together with valuable supplementary matter comprising an Introduction, a minute Synopsis of the IVork, and a copious Inciex. It may be added that the text of the original has not been subjected to any alteration or modification, even its paging being preserved

The first edition of this work was published so far back as 1834 , and a second edition was issued the same year.

No standard work on the Round Towers of Ireland has given rise to so much controversy as O'Brien's. To readers interested in Archrology and kindred subjects this new edition will doubtless present many advantages owing to its completeness.

The early editions having long been out of print, copies of the work are very scarce, and when they occur for sale, usually fetch from $35 /-$ to $40 /-$.

Demy 8vo.

Sport and Travel in High Asia. Being a Summer Ramble through Baltistan and Ladakh.

BY

Capt. F. E. S. Adair.

With a Chapter on Central Asian Trade by CAPT. S. H. GoDrREY, late British Joint Commissioner at Leh.

Illustrated by a series of beautiful Photographs and Drawings taken on the spot. 
Crown 8vo., $3 / 6$.

\section{Memoranda and Formula on Fortification and Topography. \\ For the use of Military Students. \\ BY}

\section{Colonel H. M. S. BRUNKER.}

Author of "Notes on Organzation," etc

"This is a useful contribution to the candidates' side of the struggle between examiner and examinee. The game of competitive examination has some resemblance to that of cricket, at one period the bat has the upper hand, at another the ball ; just now the examiners may be deemed to be getting the worst of it, for coaching has been elevated or reduced to a fine art. To commit the whole of the condensed notes of Colonel Brunker's little book to memory, in accordance with his suggestion, may be found difficult, but if possible of accomplishment, Burlington House and promotion examinations should have no terrors for candidates. The interleaving is exceedingly useful, and seems now to be generally adopted in educational works of this description."-Broad Arrow.

\section{RUDY不RD KIPLING.}

Crown 8vo., Gloth extra, 6/-

TENTH EDITION completing 20th Thousand.

Dedicated by Special Permission to

FIELD-MARSHAL THE RIGHT HON. LORD ROBERTS, V.C.

\section{Departmental Ditties and other Verses.}

BY

RUDYARD KIPLING.

Printed on antique wove paper, and Illustrated by Dudley Cleaver.

\section{Opinions of the Press.}

"'Pagett, M.P.,' is in this volume, and the fine lines called 'The Song of the Women,' written in praise of Lady Dufferin for her noble efforts to send medical aid to the women of India, and many another piece familiar to Mr. KIPLING'S admirers. Some of his parodies are exceedingly happy, notably those of Mr. Swinburne and ot Omar Khayyam; and there is quite enough 'stuff' in the book to make it pretty certain that the present Edition will not be the last."-Times. 
Demy 8vo., Cloth, 12'-

\title{
A Servant of 'John Company.'
}

(THE HON. EAST INDIA COMPANY.)

\section{Being the Recollections of an Indian Official.}

BY

\author{
H. G. KEENE, C.I.E,, Hon. M.A. (Oxon). \\ Author of "Sketches in Indian Ink," etc. \\ Vith a Portrait in Photogravure. \\ Illustrated by W. Simpson from the Author's Sketches.
}

"Mr. Keene has written an instructive book. He is not dull. This book presents a novel view of Indian life. It is the genial record of a man who from boyhood seems to have bent on extracting the largest possible amount of pleasure from his surroundings."-Times.

Crown 8vo, Cloth, 6/-

\section{Jason Edwards.}

And a Little Norsk.

Powerful Stories of the Far West.

BY

HAMLIN GARLAND.

Author of "Wrayside Courtships," "Rose of Dutcher's Coolly," "A Spoil of Office,"

"A Story of the Modern West," "A Member of the Third House," etc

"There is a freshness of atmosphere and a raciness of characterization about Mr. Hamlin Garland's stories which render them very agl ecable reading, and English readers who are familiar with ' $\mathrm{R} \sim \mathrm{se}$ of Dutcher's Coolly' and 'TVayside Courtships' may confidently take up this latest successor. . . . 'Jason Edwards' or 'A Little Norsk' is, each in its way, a gem."-Literary World.

Crown 8vo., Cloth, 6/-

\section{Rose of Dutcher's Coolly. \\ BY}

\section{HAMLIN GARLAND.}

"The author of 'Rose of Dutcher's Coolly' scores a marked success, chiefly, as it scems to us, because he has written his book to please himself, and with no attention to rigid rules of form or to the conventions of modern fiction. The book is the spontaneous outcome of a man"s mind-a thing much more rare now than in the days when the novelist's art was in its infancy. . . . The outcome of this and of his talent is a book striking, original, and throughout distinguished above the ordinary. - . TVe wish the book the success it deserves; and in congratulating the author on his achievement, we clesire to add a word of congratulation to the publishers, for the get-up of the book is as excellent as its matter. '- Pall Mall Gazette. 
Crown 8vo.y Cloth, 6/-

\title{
Wayside Courtships. \\ BY
}

\section{HAMLIN GARLAND.}

"' 'Wayside Courtships' is without a doubt a book to be read, and its author is a writer to be watched. WVe have not had such a welcome American arrival since the introduction of Miss Wilkins."-To-Day.

" Where so much is good it is an ungrateful task to linger unduly over faults or styles and tastc. I have read 'Wayside Courtships' with keen pleasure, and I warmly recommend the work to my readers. The two prose poems 'At the Beginning' and 'The End of Love is Love' are pregnant with the beauty closcly akin to the mystical silhouettes in Olive Schreiner's 'Dreams." "-Critic.

"It would be difficult to decide in which of the many beautiful characteristics lies the chief charm of these brief sketches. The keen obscrving powers of the author have resulted in the presentation of exquisitely natural scenes which are vividly pictured by a skilful pen."-Liverpool Mercury.

Crown 8vo, 6/-

\section{A Galaxy Girl.}

A New Novel.

BY

\section{LINCOLN SPRINGFIELD.}

"One would welcome a dozen such chapters as the one headed, 'A permanent object lesson to gamblers.' There is no clumsiness, no indecision, in Mr. Springfield's workmanship. His style is clean and correct, his humour is natural, and he has a grip of human nature and a skill in the contrivance of plot and exciting incident which give the impression that, admirable though this novel is, it gives only an indication of his fullest possibilities as a writer of popular fiction."-Daily Mail.

\section{The Shepherdess of Treva.}

\author{
A New Novel. \\ BY \\ PAUL CUSHING. \\ Author of "The Blacksmith of Voe," "I" Th' Thorn," etc.
}

"Mr. Cushing has achieved a very great success in "The Shapherdess of Treva." "-Academy. 
Demy 8vo., Cloth, 6s.

\title{
The Captain of the "Mary Rose." BY
}

\author{
W. LAIRD CLOWES. \\ Author of "The Naval Pocket Book."
}

Illustrated by the Chevalier de Martino and Fred T. Jane.

SEVENTH EDITION.

"The most notable Book of the season."-Standard.

Crown 8vo. Cloth, 3/6.

\section{Notes on Stable Management in India and the Colonies. \\ BY}

\author{
Vety.=Major J. A. NUNN, F.R.C.V.S.
}

SECOND EDITION, revised and enlarged, with a Glossary.

CONTENTS.-Food, Water, Air, and Ventilation, Grooming, Gear, etc.

"Soldiers and others abont to leave England for the East for the first time should not fail to possess themselves of a copy of this work. They can read it on the voyage, and find themselves all the better for the instruction conveyed by the time they reach the other side."-Field.

Post 8vo, Cloth Gilt, 7/6.

\section{Echoes of Old Calcutta.}

A most interesting series of Sketches of Calcutta Life, chiefly towards the close of the last century.

BY

H. E. BUSTEED, M.D., C.I.E.

THIRD EDITION, carefully revised and enlarged, with additional Illustrations.

"It is a pleasure to reiterate the warm commendation of this instructive and lively volume which its appearance called forth some few years since. It would be lamentable if a book so fraught with interest to all Englishmen should be restricted to Anglo-Indian circles. A fresh instalment of letters from Warren Hastings to his wife must be noted as extremely interesting, while the papers on Sir Phillip Francis, Nuncomar, and the romantic career of Mrs. Grand, who became Princess Benevento and the wife of Talleyrand, ought by now to be widely known."-Saturday Revieze. 
Grown 8vo., Gloth, 6/-.

\section{Training and Horse Management in India. \\ BY}

Capt. M. HORACE HAYES, F.R.C.V.S.

FIFTH EDITION.

" We entertain a very high opinion of Capt. Hayes' book on 'Horse Training and management in India,' and are of opinion that no better guide could be placed in the hands of either amateur horseman or veterinary surgeon newly arrived in that important division of our empire."-Veterinary fournal.

12 mo., sewed, $2 /-$

\section{Onoocool Chunder Mookerjee.}

A Memior of the late Justice Onoocool Chunder Mookerjee.

BY

\section{MOOKERJEE.}

\section{FIFTH EDITION.}

"The reader is earnestly advised to procure the life of this gentleman, written by his nephew, and read it."-The Tribes on My Frontier.

Grown 8vo, Gloth, 12/-

\section{A Text Book of . . \\ Indian Military Law. BY}

Capt. E. H. BERNARD, Cantonment Magistrate, Mandalay.

Comprising the Indian Articles of WVar fully annotated, the Indian Penal Code and the Indian Evidence Act, and has, in the form of Appendices, all existing Regulatic is with regard to the Procedure of Courts-martial and Forms of Charges. With Tables showing the Powers and Jurisdiction of different Courts-martial, and the difference in Procedure and Evidence between English Military Law and Indian Military Law.

"A well-arranged and clearly printed Manual . . . . . with ample notes, marginal references and appendices. . . Every officer in India should possess a copy of this handy compilation."-Home Neres. 
Grown 8vo, 5/-

\title{
Indian Articles of War.
}

\author{
BY \\ Major C. E. POYNDER.
}

Revised to date. With an Appendix containing Definitions, Rules of Procedure, Forms of Charges, Statement of Objects and Reasons and an Index.

"The annotations are very good, and we commend the volume to all concerned in the Military Legal Procedure of India."- Army and Nav'y Gazette.

Grown 8vo, Cloth Gilt, 6/-

\section{A Naturalist on the Prowl. BY}

\section{E. H. AITKEN.}

Illustrated by a series of 8o Drawings by R. A. Sterndale, F.R.G.S., F.Z.S., Author of "Mammalia of India," "Denizens of the Jungle," "Seonee," etc., who has studied and sketched animals of all kinds in their habitat and at work.

\section{SECOND EDITION.}

"It is one of the most interesting books upon Natural History that we have read for a long time. It is never dull, and yet solid information is conveyed by nearly every page."-Daily Chronicle.

Demy 8vo., Cloth, 15:-

\section{The Rod in India.}

Being Hints how to obtain Sport, with remarks on the Natural History of Fish and their Culture.

BY

\section{H. S. THOMAS, F.L.S.}

Author of "Tank Angling in India."

MADRAS CIVIL SERVICE, RETIRED.

THIRD EDITION, revised, with numerous full-page and other Illustrations.

"A book to read for pleasure at home, as well as to use as a handbook of cxceeding value to the angler who may be already there, or intending to visit India." Land and Water. 
Crown 8vo, Gloth, Gilt, 6/-

\section{Lays of Ind.}

Comical, Satirical, and Descriptive Poems illustrative or Anglo-Indian Life.

\section{$\mathrm{BY}$}

\section{Major W. YELDHAM ("ALIPH CHEEM").}

Illustrated By the AUthor, Lionel INGlis, AND others.

TENTH EDITION.

“The 'Lays' are not only Anglo-Indian in origin, but out-and-out Anglo-Inclian in sulject and colour. To one who knows something of life at an Indian 'station' they will be especially amusing. Their exuberant fun at the same time may well attract the attention of the ill-defined individual known as "the general reader." "Scotsman.

Crown 8vo., Gloth Gilt, 6/.

\section{The Tribes on my Frontier.} An Indian Naturalist's Foreign Policy.

BY

\section{E. H. AITKEN.}

With Fifty Illustrations by F. C. Macrae.

SIXTH EDITION.

"This is a delightful book, irresistibly funny in description and illustration, but full of genuine science too. - . There is not a dull or uninstructive page in the whole book." - Knowledge.

Grown 8vo., Pictorial Cloth, 6/-

\section{Behind the Bungalow. \\ BY}

E. H. AITKEN.

Author of "Tribes on My Frontier."

Fifth Edition.

Illustrated By F. C. MACRAE.

“'There is plenty of fun in 'Behind the Bungalow,' and more than fun for those with eyes to see. These sketches may have an educational purpose beyond that of mere amusement; they show through all their fun a keen observation or native character and a just appreciation of it."-The World.

Foolscap 8vo., Gloth, 36 .

\section{Medical Hints for Hot Climates And for those out of reach of Medical Aid. BY}

CHAS. HEATON, M.D.

"The title of this work is sufficiently explanatory of its nature. It is what it pretends to be-a portable book of medical reference, with plain practical hints and advice for people residing at out-stations or travelling in hot climates where skilled medical aid is not readily available for the treatment of emergent sickness or injury." Lancet. 
Royal 8vo., Strongly half-bound, 36/-

\section{Thacker's Indian Directory.}

Embracing the whole of British India, Burmah, and Native States.

With complete and detailed Information of the rities of Calcutta, Madras, Bombay, Allahabad, Lahore, Simla, Rangoon, etc.

Tea, Indigo, Coffee, Silk, Sugar, Lac, Cinchona, Jute, Cotton, Paper, Collieries, Mines, etc.

Almanack, Army List, Civil List (with Salaries), Railway List, Newspaper Directory and General Information, with Map of India and Two Maps of Calcutta.

PUBLISHED ANNUALLY. THIRTY-SIXTH YEAR OF PUBLICATION 
Royal 8vo., Boards, $7 / 6$.

\section{THACKER'S}

\section{Directory of the Chief Industries of India.} WITH WHICH IS INCORPORATED

\section{A LIST OF TEA COMPANIES AND GARDENS,}

INDIGO AND COFFEE ESTATES, WITH THEIR FHCTORY MARKS; AND A

DIRECTORY OF TEA, COFFEE, CINCHONA,

CARDAMOM ESTATES IN CEYLON, WITH TWO MAPS,

CONTENTS.

Breweries, Carpet Manufactories, Cinchona, Coal Mines, Coffee (India and Ceylon), Cotton Mills and Presses, Dairy Farms, Distilleries, Flour Mills, Gold Mines, Ice Companies, Indigo, Iron Works, Jute Presses and Mills, Lac, Orchards, Paper Mills, Petroleum, Potteries, Quarries, Rice Mills, Roperies, Salt, Saw Mills, Silk, Sugar, Tea Companies and Gardens in India and Ceylon, Tobacco, Wool, etc. 
CLOTH CASE, 7/6.

THACKER'S

\section{MAP OF INDIA.}

WITH

INSET MRPS

OF THE

VARIOUS PRODUCTS OF INDIH AND OF THE TER DISTRICTS.

SKETCH PLANS OF CALCUTTA, BOMBAY AND MADRAS.

\section{Edited by J. G. BARTHOLOMEW.}

Corrected to date, with Railways, Political Changes, and an Index of 10,000 Names.

Being every place mentioned in "Hunter's Imperial Gazetteer."

"An excellent Map."-Glasgow Herald.

"This is a really splendid map of India, produced with the greatest skill and care."-Army and Navy Gazette.

"For compactness and completeness of information few works surpassing or approaching it have been seen in cartography."-Scotsman. 
Grown 8vo., Handsomely Bound.

\section{THACKER'S SIX SHILLING SERIES $\mathrm{OF}$

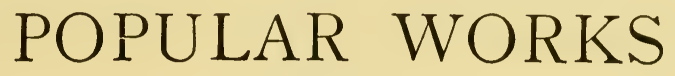

Hunting Reminiscences.

BY

\section{ALFRED E. PEASE, M.P.}

With Illustrations by the late Sir Frank Lockwood, Cuthbert Bradley, Heywood Hardy, and from Photographs.

\section{Ladies in the Field.}

Sketches of Sport.

Edited by the LADY VIOLET GREVILLE.

\section{The Sportsman's Manual}

BY

Lieut.-Col. R. H. TYACKE.

TENTH EDITION.

DEDICATED TO LORD ROBERTS, V.C.

Departmental Ditties and other Verses.

BY

\section{RUDYARD KIPLING.}

Printed on antique wove paper, and Illustrated by Dudley Cleaver.

$$
\text { Lays of Ind. }
$$

Comical and Satirical Yerses of Anglo-Indian Life and Customs.

BY

Major W. YELDHAM ("ALIPH CHEEM").

Illustrated by the Author, Lionel Inglis, and others

$\because$ New Works are constantly being added to this Series. 


\section{PHIL MAY'S}

\section{ILLUSTRATED : ANNUAL.}

PUBLISHED ANNUALLY.

.. Price One Inbilling . .

FOUNDED 1891.

Contains Stories by the best known Writers of the day.

Fllustrated be [phil silane and otber Artists.

Editorial Offices : 2, CREED LANE, LONDON, E.C. 


